ISSN 2415-8860 (online)

ISSN 0372-4123 (print)

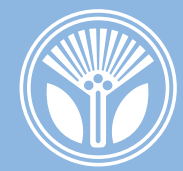

UKRAINIAN

BOTANICAL JOURNAL

Founded 1921

A journal for botany \& mycology

УКРАЇНСЬКИЙ БОТАНІЧНИЙ ЖУРНАЛ $2021 \cdot 78$ (4)

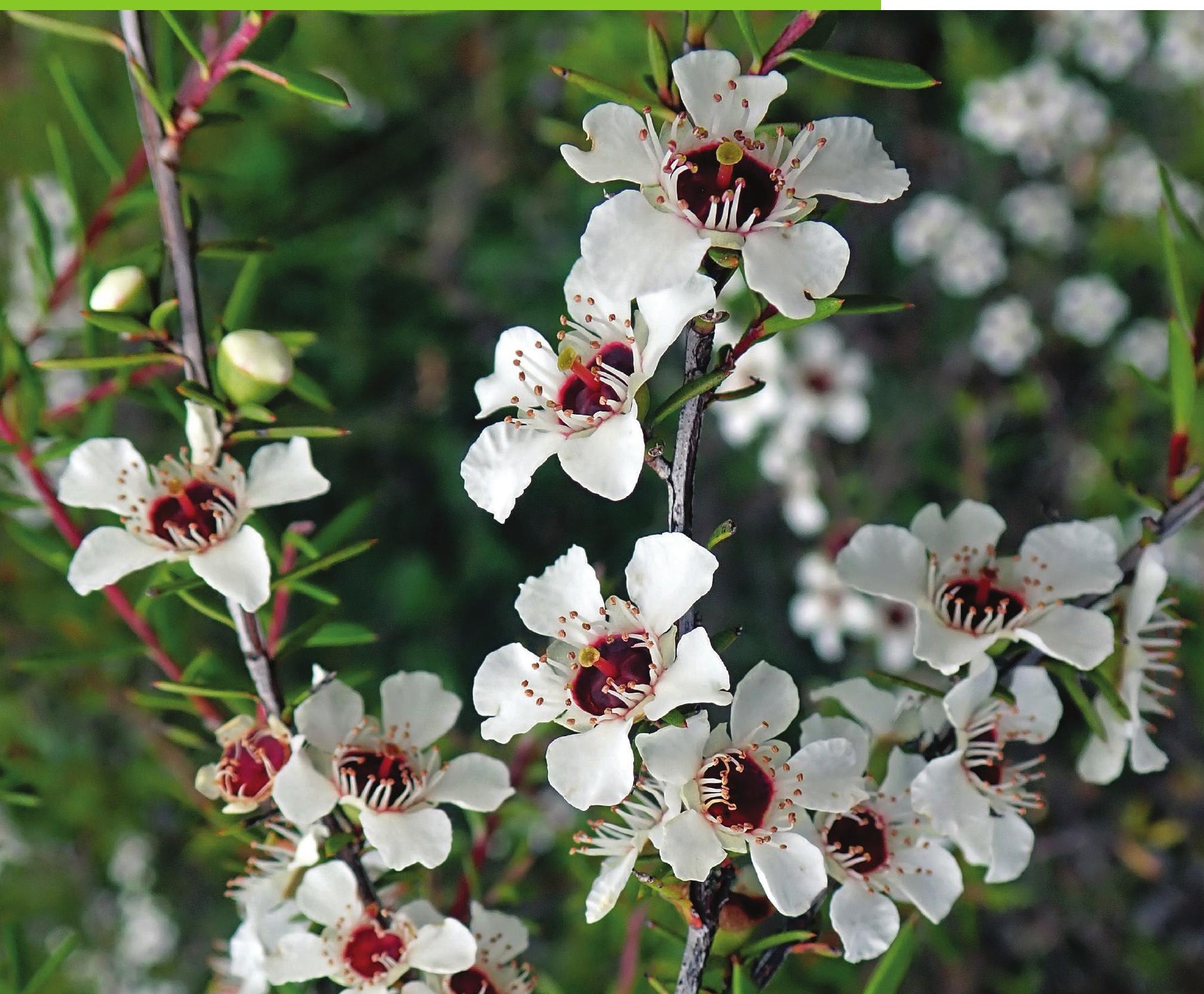


УКРАЇНСЬКИЙ БОТАНІЧНИЙ ЖУРНАЛ публікує статті з усіх напрямів ботаніки та мікології, в тому числі із загальних питань, систематики, флористики, геоботаніки, екології, еволюційної біології, географії, історії флори та рослинності, а також морфології, анатомії, фізіології, біохімії, клітинної та молекулярної біології рослин і грибів. Статті, повідомлення та інші матеріали публікуються в таких основних розділах: Загальні проблеми та огляди, Систематика, флористика, географія рослин, Гриби $і$ грибоподібні організми, Геоботаніка, екологія, охорона рослинного світу, Червона книга України, Флористичні знахідки, Мікологічні знахідки, Структурна ботаніка, Біотехнологія, фізіологія, біохімія, Клітинна та молекулярна біологія, Гербарна справа, Історія науки, Новини та дискусї, Ювілейні дати, Втрати науки, Рецензії та новини літератури.

Статті друкуються українською та англійською мовами

UKRAINIAN BOTANICAL JOURNAL is a scientific journal publishing articles and contributions on all aspects of botany and mycology, including general issues, taxonomy, floristics, vegetation science, ecology, evolutionary biology, geography, history of flora and vegetation as well as morphology, anatomy, physiology, biochemistry, cell and molecular biology of plants and fungi. Original articles, short communications and other contributions are published in sections General Issues and Reviews, Plant Taxonomy, Geography and Floristics, Fungi and Fungi-like Organisms, Vegetation Science, Ecology and Conservation, Red Data Book of Ukraine, Floristic Records, Mycological Records, Structural Botany, Biotechnology, Physiology and Biochemistry, Cell Biology and Molecular Biology, Herbarium Curation, History of Science, News and Views, Anniversary Dates, In Memoriam, Reviews and Notices of Publications.

Publication languages: Ukrainian and English

\section{РЕДАКЦІЙНА КОЛЕГІЯ}

Головний редактор - Сергій Л. МОСЯКІН

Заступники головного редактора - Ганна В. БОЙКО, Віра П. ГАЙОВА

Соломон П. ВАССЕР, Філіп ВЕРЛООВ (Бельгія), Василь П. ГЕЛЮТА, Зігмантас ГУДЖИНСКАС (Литва), Яків П. ДІДУХ, Дмитро В. ДУБИНА,

Олена К. ЗОЛОТАРЬОВА, Сергій Я. КОНДРАТЮК,

Єлізавета Л. КОРДЮМ, Ірина А. КОРОТЧЕНКО, Ірина В. КОСАКІВСЬКА, Кароль МАРГОЛЬД (Словаччина), Евіатар НЕВО (Ізраїль), Віктор І. ПАРФЬОНОВ (Білорусь), Пітер РЕЙВЕН (США), Марина М. СУХОМЛИН, Сусуму ТАКАМАЦУ (Японія), Микола М. ФЕДОРОНЧУК, Олександр Є. ХОДОСОВЦЕВ, Петро М. ЦАРЕНКО, Ілля І. ЧОРНЕЙ, Мирослав В. ШЕВЕРА, Наталія М. ШИЯН, Богдан ЯЦКОВЯК (Польща) Відповідальний секретар Марія Д. АЛЕЙНІКОВА

\section{EDITORIAL BOARD}

Editor-in-Chief - Sergei L. MOSYAKIN

Associate Editors - Ganna V. BOIKO Vera P. HAYOVA

Illya I. CHORNEY, Yakiv P. DIDUKH, Dmytro V. DUBYNA, Mykola M. FEDORONCHUK, Zigmantas GUDŽINSKAS (Lithuania), Vasyl P. HELUTA, Bogdan JACKOWIAK (Poland), Olexander E. KHODOSOVTSEV, Sergey Y. KONDRATYUK, Elizabeth L. KORDYUM, Iryna A. KOROTCHENKO, Iryna V. KOSAKIVSKA, Karol MARHOLD (Slovakia), Eviatar NEVO (Israel), Victor I. PARFENOV (Belarus), Peter RAVEN (USA), Myroslav V. SHEVERA, Natalia M. SHYIAN, Maryna M. SUKHOMLYN, Susumu TAKAMATSU (Japan), Petro M. TSARENKO, Filip VERLOOVE (Belgium), Solomon P. WASSER, Olena K. ZOLOTAREVA Editorial Assistant - Mariya D. ALEINIKOVA

На першій сторінці обкладинки: Leptospermum repo de Lange \& L.M.H.Schmid під час цвітіння у locus classicus - на території болота з домінуванням видів родини Restionaceae, південний бік дороги Айленд Блок, водно-болотні угіддя Вангамаріно, Вайкато, Північний острів, Аотеароа / Нова Зеландія (див. статтю де Ланге, Шмід на стор. 247-265 у цьому номері)

Фото (C) Пітер Дж. де Ланге, 12 грудня 2020 р.

Front page: Leptospermum repo de Lange \& L.M.H.Schmid - flowering specimen growing in restiad bog at the type locality, the southern side of Island Block Road, Whangamarino wetlands, Waikato, Te Ika a Maui / North Island, Aotearoa / New Zealand (see article by de Lange \& Schmid on pages $247-265$ in this issue) Photo by (C) Peter J. de Lange, 12 December 2020

Редакція "Украӥнського ботанічного журналу"

Інститут ботаніки НАН України

вул. Терещенківська 2, Київ 01601, Україна
+380442354182 secretary_ubzh@ukr.net https://ukrbotj.co.ua 


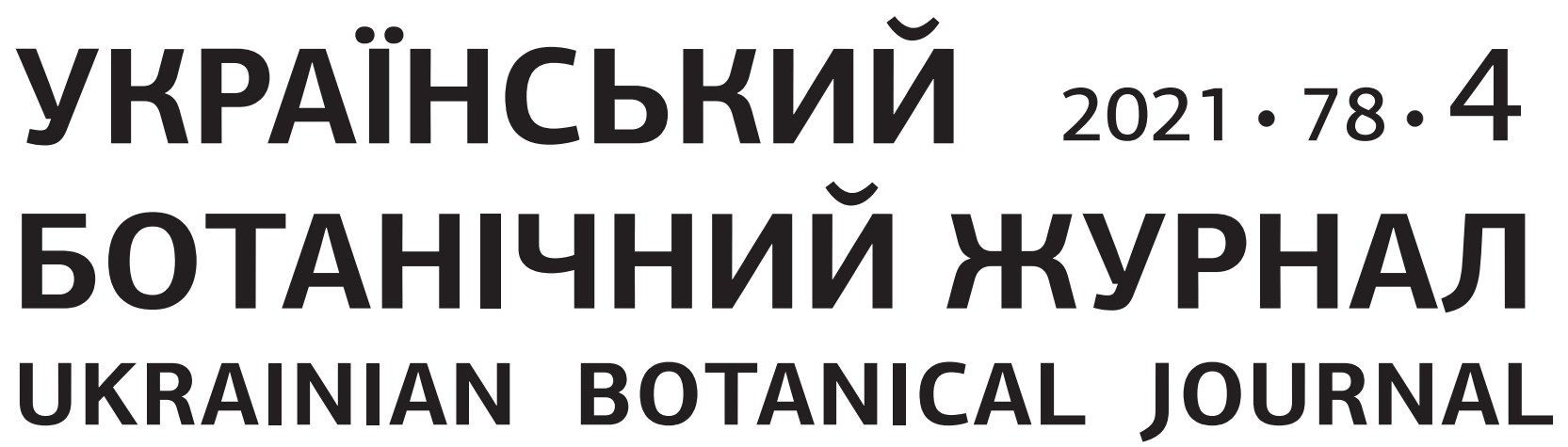

НАУКОВИЙ ЖУРНАЛ • ЗАСНОВАНИЙ 1921 р. • SCIENTIFIC JOURNAL • PUBLISHED SINCE 1921

\section{M I C T}

\section{Систематика, флористика, географія рослин}

де Ланге П.Дж., Шмід Л.М.Г. Leptospermum repo (Myrtaceae), новий вид із оселищ торфових боліт у північній Аотеароа / Новій Зеландії, відокремлений з групи Leptospermum scoparium s. 1 . . . . . . . . . . . . . . . . . . . . . . . . . . 247

Мосякін С.Л. Номенклатурні та таксономічні коментарі щодо деяких представників роду Dysphania

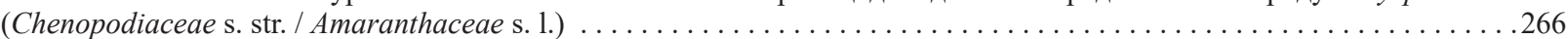

\section{Гриби і грибоподібні організми}

Гелюта В.П., Коритнянська В.Г. Перша знахідка Phyllactinia moricola (Erysiphales, Ascomycota) на Morus alba

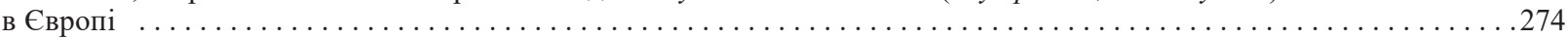

Геоботаніка, екологія, охорона рослинного світу

Дідух Я.П., Розенбліт Ю.В., Буджак В.В., Чорней I.І., Токарюк А.І. Рослинність Дністровського каньйону та

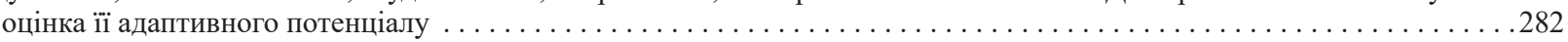

\section{Червона книга Украӥни}

Ролечек Я. Недавня знахідка Ophrys insectifera (Orchidaceae) в Україні - чи переживе цей вид ще одне століття?

\section{Флористичні знахідки}

Давидова А.О., Орлова-Гудім К.С., Шевченко І.В., Давидов Д.А., Дзеркаль В.М. Перші знахідки Elodea nuttallii

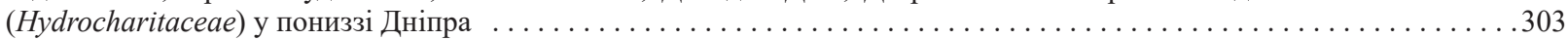

\section{Ювілейні дати}

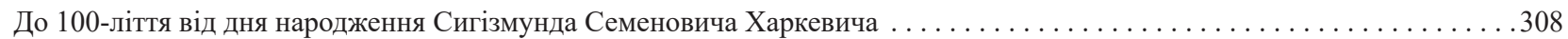




\section{CONTENTS}

\section{Plant Taxonomy, Geography and Floristics}

de Lange P.J., Schmid L.M.H. Leptospermum repo (Myrtaceae), a new species from northern Aotearoa / New Zealand peat

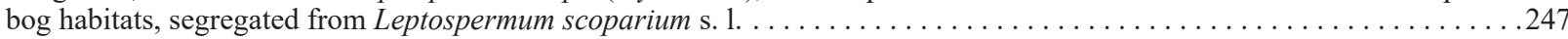

Mosyakin S.L. Nomenclatural and taxonomic comments on some representatives of Dysphania (Chenopodiaceae s. str. /

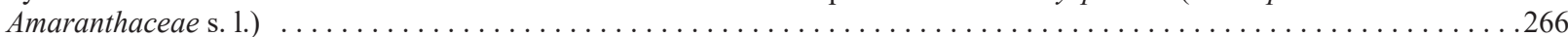

\section{Fungi and Fungi-like Organisms}

Heluta V.P., Korytnianska V.G. First record of Phyllactinia moricola (Erysiphales, Ascomycota) on Morus alba in Europe . . . 274

Vegetation Science, Ecology, Conservation

Didukh Ya.P., Rozenblit Yu.V., Chorney I.I., Budzhak V.V., Tokariuk A.I. Vegetation of the Dniester Canyon and assessment

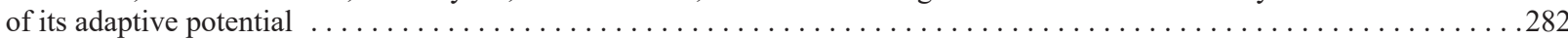

\section{Red Data Book of Ukraine}

Roleček J. A recent find of Ophrys insectifera (Orchidaceae) in Ukraine - will it survive another 100 years? .297

\section{Floristic Records}

Davydova A.O., Orlova-Hudim K.S., Shevchenko I.V., Davydov D.A., Dzerkal V.M. The first record of Elodea nuttallii

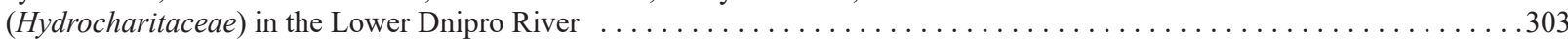

\section{Anniversary Dates}

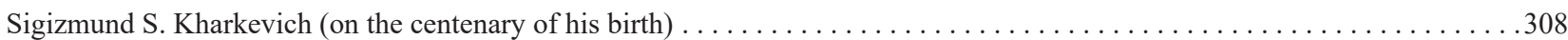

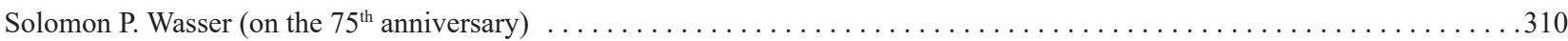




\title{
Leptospermum repo (Myrtaceae), a new species from northern Aotearoa / New Zealand peat bog habitats, segregated from Leptospermum scoparium s. I.
}

\author{
Peter J. de LANGE* (D), Luzie M.H. SCHMID (D) \\ Unitec Institute of Technology, School of Environmental \& Animal Sciences, Private Bag 92025, Victoria Street West, Auckland \\ 1142 , New Zealand
}

\begin{abstract}
Leptospermum repo de Lange \& L.M.H.Schmid sp. nov. (Myrtaceae) is segregated from L. scoparium J.R.Forst. \& G.Forst. (sensu lato). The new species is endemic to the peat bogs of the Waikato, Bay of Plenty, and adjacent eastern ranges of the northern portion of Te Ika a Maui / North Island, Aotearoa / New Zealand. The new species belongs to the northern Te Ika a Maui / North Island clade of L. scoparium s. 1., from whose other members it is morphologically distinguished by its gracile, spindly, open-branched growth habit; widely divergent, longer, linear, linear-lanceolate (rarely filiform), shortly cuspidate leaves; flowers with white petals, stamens mostly with white filaments (very rarely tinged pink near base), and by the style and stigma which are usually green (very rarely pink). Leptospermum repo now occupies ca. $10 \%$ of its former peat bog habitat, where aside from a few protected peat bogs the species is still in decline through loss of its habitat. A more recent potential threat to L. repo is myrtle rust disease, caused by Austropuccinia psidii, an exotic rust first detected in Aotearoa / New Zealand in May 2017. This rust poses a serious threat to the Myrtaceae of Aotearoa / New Zealand, for which there is at present no known effective treatment to prevent the death of infected hosts. Therefore, due to the historic loss of habitat, a threat which is still ongoing, causing the decline of many L. repo populations; and the potential threat of Austropuccinia psidii to this species, the listing proposed for the species (as Leptospermum aff. scoparium (c) (AK191319; "Waikato peat bog") by the New Zealand Indigenous Vascular Plant Threat Listing Panel of "Threatened / Nationally Critical DP, De" is here upheld.
\end{abstract}

Keywords: Aotearoa / New Zealand, Leptospermum, Leptospermum repo sp. nov., Leptospermum scoparium, Myrtaceae, new species, taxonomy

Article history. Submitted 15 June 2021. Revised 02 August 2021. Published 30 August 2021

Citation. de Lange P.J., Schmid L.M.H. 2021. Leptospermum repo (Myrtaceae), a new species from northern Aotearoa / New Zealand peat bog habitats, segregated from Leptospermum scoparium s. 1. Ukrainian Botanical Journal, 78(4): 247-265. https://doi.org/10.15407/ukrbotj78.04.247

*Corresponding author (e-mail: pdelange@unitec.ac.nz)

\section{Introduction}

Leptospermum J.R.Forst. \& G.Forst. (Myrtaceae), a primarily Australasian genus, comprises ca. 87 species (Thompson, 1989; Bean, 1992; Lyne, 1993; Lyne, Crisp, 1996; Bean, 2004). The type of the genus is L. scoparium J.R.Forst. \& G.Forst. As currently circumscribed (Thompson, 1989; Sykes, 2016) L. scoparium s. 1. is a variable species complex of trees and shrubs found in eastern Australia, Aotearoa / New Zealand, and the Cook Islands (Rarotonga).

Leptospermum scoparium was succinctly described by Forster \& Forster (1776: 48 [72], tab. 36: f-1) "L. fol., sparsis, ovato-lanceolatis" (however, Table XXXVI [36] can be considered as an analytical illustration) from specimens that were probably collected from Dusky Sound, Fiordland, Aotearoa / New Zealand (Allan 1961; Buys et al., 2019). The perfunctory nature of the Forsters'

(C) 2021 P.J. de Lange, L.M.H. Schmid. Published by the M.G. Kholodny Institute of Botany, NAS of Ukraine. This is an open access article under the terms of the Creative Commons Attribution License (http://creativecommons.org/licenses/by/4.0/), which permits use, distribution, and reproduction in any medium, provided the original work is properly cited 
diagnosis, has, understandably, failed to address the considerable variation within the species as it is now circumscribed (Thompson, 1989) either in its narrow or wide circumscription. Not surprisingly with a species hitherto believed to range across eastern Australia, Aotearoa / New Zealand and Rarotonga (Fig. 1.), there have been attempts by taxonomists to define more precisely the natural variation.

The first to address this variation was William Aiton who placed Leptospermum scoparium into Philadelphus L., as P. scoparius (J.R.Forst. \& G.Forst.) Aiton and recognised within it two varieties, var. linifolius Aiton and var. myrtifolius Aiton (Aiton, 1789: 156). Of these, var. linifolius is illegitimate because it included the type of Leptospermum scoparium s. str. (Buys et al., 2019), and thus the variety should be called P. scoparius var. scoparius (autonym, Art. 26 of the ICN: Turland et al., 2018). Twenty-five years later, William Townsend Aiton (1811: 181), the eldest son of William Aiton, returned Philadelphus scoparius and its varieties to Leptospermum. Hooker (1853) in his Flora NovaeZelandiae recognised a further variety from that country, L. scoparium var. prostratum Hook.f., with the diagnosis 'caule prostrato, ramulis ascendentibus, foliis late ovatis orbiculatisve squarroso-recurvis', for which he gave no specific locations. Later, Aotearoa / New Zealand based botanist Kirk (1899) contributed a further variety, L. scoparium var. parvum Kirk, to cover specimens with coriaceous, ovate, sharp-tipped leaves, smaller flowers and glabrous hypanthia, which he had collected in the vicinity of Wellington. The most recent contribution to defining the variation of Aotearoa / New Zealand populations of L. scoparium was by Cockayne (1917a) who described $L$. scoparium var. incanum Cockayne from the sand country of the far north of Northland, Te Ika a Maui / North Island, Aotearoa / New Zealand.

Acceptance of these varieties has been variable. Hooker (1867: 728), for example, regretted his earlier naming of var. prostratum, and with respect to that variety and the others then recognised he stated that because "the species of the genus are ..., so variable" the recognition of further taxa from within it was unwise. Cheeseman was also uncertain in that case; in his first flora treatment (Cheeseman, 1906) he accepted the then named varieties without comment; however, nineteen years later he reduced all, except Cockayne's var. incanum, into synonymy within the widely circumscribed $L$. scoparium (Cheeseman, 1925). Allan (1961) offered no advance on Cheeseman (1925), if anything adding further confusion with his assessment of var. incanum, for which he offered an incomplete treatment. Twenty-seven years later, Webb et al. (1988) only recognised the one species $L$. scoparium for Aotearoa / New Zealand, rejecting var. incanum altogether.

Collectively then, the various Aotearoa / New Zealand flora treatments of Leptospermum scoparium s. 1. have retained the impression of a highly variable and morphologically "plastic" species, initially worthy of further infraspecific taxonomic segregation but now apparently not. In part, this modern view reflects the conservative approach to species limits adopted by Joseph Dalton Hooker and Thomas Cheeseman, whilst the treatment meted out by Allan (1961) seems to have been strongly influenced by his mentor Leonard Cockayne, an opinionated, politically astute though rather forceful botanist (Thomson, 1983, 2021; de Lange, 2019). Cockayne had by the early 1900s developed a strong dislike of taxonomy, taxonomic concepts and most Aotearoa / New Zealand based taxonomists (Cockayne, 1917b, 1919, 1926; Moore, 1967; Thomson, 1983, 1990, 2021; de Lange, 2019) such that he was happy to relegate the Leptospermum scoparium varieties established by Aiton, Hooker, and Kirk to mere "footnotes" in the annals of that species, though notably he retained his own contribution to the taxonomic resolution of that species variation, var. incanum, as unquestionable.

From an Aotearoa / New Zealand view point, Cockayne's dismissal of Leptospermum scoparium taxonomic segregates (either infraspecific or speciesrank ones) seems to be at the root of the modern view that this species though highly variable, with well-marked races is best treated as belonging to a single species (Webb et al., 1988). The question is why did Cockayne have this view? The answer lies in the fact that while Cockayne had little interest in taxonomy, he exerted a strong influence on how he felt the discipline should be practised in Aotearoa / New Zealand (Cockayne, 1926; Moore, 1967; Thomson, 1990; de Lange, 2019), central to this was his view that taxonomic conclusion must result from a comprehensive analysis not only of morphological variation but also whether that variation was represented by "true breeding races" (Cockayne, 1917a, 1919, 1926). For Leptospermum scoparium then, Cockayne felt that the variation people were describing, required formal testing using what he called "experimental taxonomy" whereby the stability of characters in a plant were tested by cultivation. Without such tests Cockayne was mostly dismissive of taxonomic works (Cockayne, 1926; Moore, 1967). 


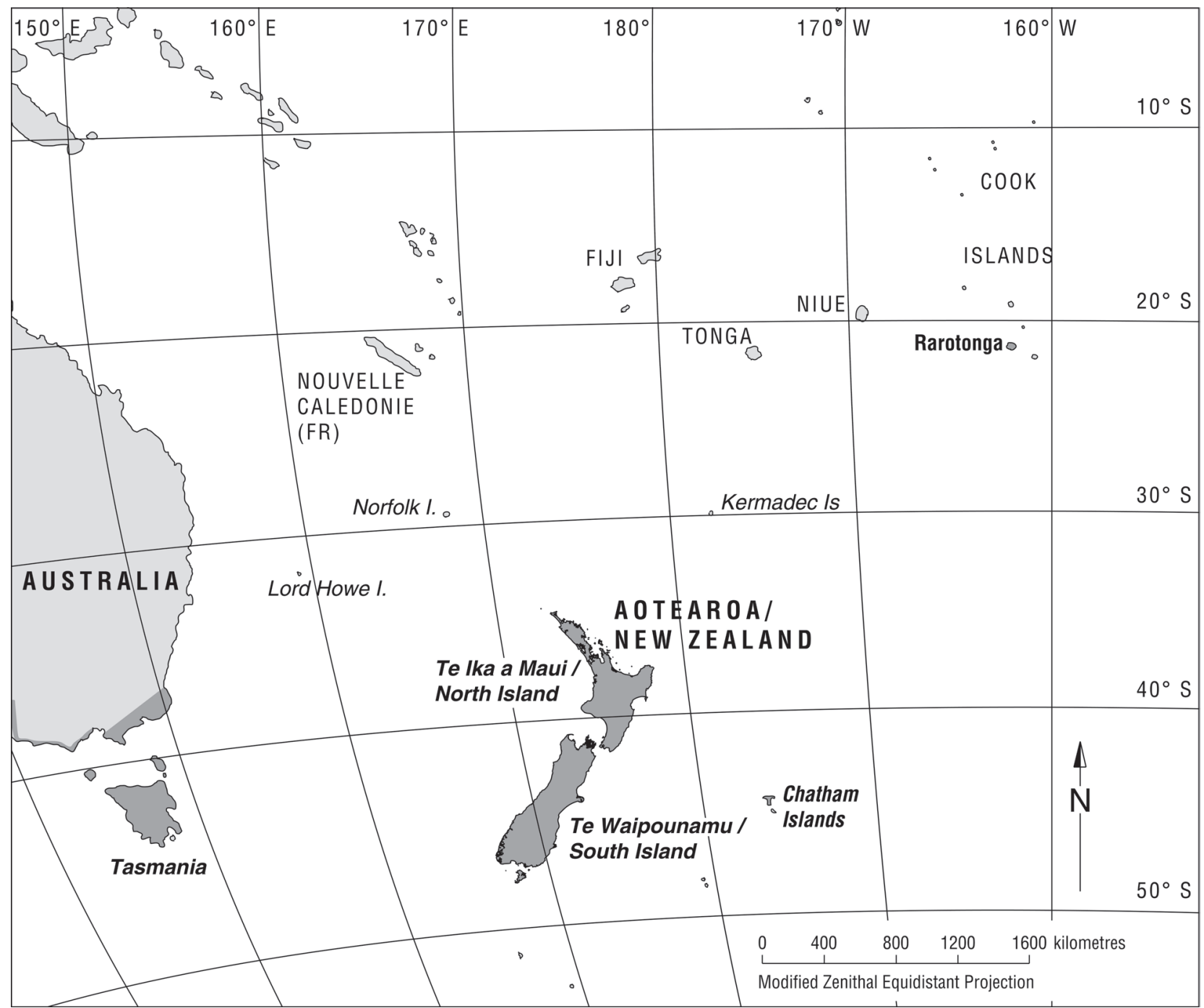

Fig. 1. Distribution of Leptospermum scoparium s. 1. as accepted by Thompson (1989) and Sykes (2016) which encompasses (shaded areas only) South Eastern Australia, Tasmania, Aotearoa / New Zealand, Chatham Islands and Rarotonga (Cook Islands)

The "experimental taxonomy" advocated by Cockayne has since been well-established, though not by design rather by accident, as Leptospermum scoparium s. 1. is an important horticultural plant (Dawson, 1997a, b), and now increasingly, one of economic value because of the oils and honey obtained from the species (Molan, Russell, 1988; Molan et al., 1988; Molan, 1995; Perry et al., 1997; Porter et al., 1998), The result has been that well established "races" and wild-selected cultivars have been widely grown in "common garden experiments" from seed and cuttings for many decades, so demonstrating their stability under a range of conditions (Metcalf, 1972, 1993; Dawson, 1997a, b).
Outside Aotearoa / New Zealand the concept of Leptospermum scoparium (Thompson, 1989; Sykes, 2016) remains that of a single variable species indigenous to Eastern Australia, Tasmania, and Aotearoa / New Zealand and Rarotonga (Fig. 1). However, in her treatment of the genus Thompson (1989) paid little attention to the variation within the Aotearoa / New Zealand range of $L$. scoparium, possibly because she saw that variation as a purely Aotearoa / New Zealand issue outside her remit. Now that Leptospermum scoparium has significant economic value (McDonald et al., 2018; Taunton, 2021), there is increased interest in resolving whether the species (in the strict sense) is endemic to Aotearoa / New Zealand or not. Buys et al. (2019) undertook a limited 
phylogenetic study of Australian and New Zealand members of Leptospermum scoparium s. 1. They found a mainland Australian, Tasmanian and New Zealand clade. That data infers that Leptospermum scoparium s. str. is endemic to New Zealand, a revelation strengthened by a much wider sampling of the species using pooled whole genome re-sequencing of $76 \mathrm{~L}$. scoparium and outgroup populations from Aotearoa / New Zealand and Australia (Koot et al., in sub.) confirming the same pattern. Therefore, for this paper we treat Leptospermum scoparium group as an endemic Aotearoa / New Zealand lineage.

Within Aotearoa / New Zealand Leptospermum scoparium, Buys et al. (2019) recognised three clades: (1) northern Te Ika a Maui / North Island, (2) Central Te Ika a Maui / North Island, and (3) Te Wai Pounamu / South Island (which includes the type of $L$. scoparium). To this Koot et al. (submitted, preprint) added two more clades, the Tairawhiti / East Cape (Te Ika a Maui / North Island) and the North West Nelson (Te Wai Pounamu / South Island) clads.

This paper is concerned with one of the races of Leptospermum scoparium found in the northern Te Ika a Maui / North Island clade, an extremely fine (linearleaved) race found in restiad high moor and low moor peat bogs throughout the Waikato lowlands. That race was noted by Allan (1961) who discussed a specimen (CHR [BD] 76026, A.L. Poole s.n.) within his interpretation of what he thought Leptospermum scoparium var. linifolium might represent. That specimen had been collected from a Phormium community "north of Kaihere by the Piako River" (ca. $37.324769^{\circ} \mathrm{S}, 175.506879^{\circ} \mathrm{E}$, ca. 5 m a.s.1.). This location was probably a portion of the now mostly drained Torehape Peat Bog. This fine (linear-leaved) race has long been recognised as potentially distinct by field botanists working in Waikato Peat Bogs; most recently it has been recorded in the literature as Leptospermum aff. scoparium (c) (AK191319; "Waikato peat bog") on the basis that it is now threatened and that its taxonomic status needed resolution (de Lange et al., 2018). The inclusion of this race within the northern Te Ika a Maui / North Island clade of Buys et al. (2019) suggests a relationship to Leptospermum scoparium var. incanum, and two other races $L$. aff. scoparium (a) (AK284541; Auckland) and L. aff. scoparium (b) (AK247250; "coastal silver prostrate", also informally recognised by de Lange et al., 2018). From these taxa, Leptospermum aff. scoparium (c) (AK191319; "Waikato peat bog") differs ecologically through its restriction to peat bogs, and morphologically by its gracile growth habit, consistently narrower linear leaves, white staminal filaments, and green style and stigma. This race is also broadly sympatric with $L$. aff. scoparium (a) (AK284541; Auckland) throughout its range, and in places is found growing syntopically, with no evidence of hybridisation.

Because of this sympatry and morphological disparity from other members of the Aotearoa / New Zealand Leptospermum scoparium clade, we describe here Leptospermum aff. scoparium (c) (AK191319; "Waikato peat bog") as a new species. The remaining members of the northern Te Ika a Maui / North Island plants will form the focus of a separate paper.

\section{Materials and Methods}

This article is based on the study of live plants cultivated over the last three decades in Auckland, and Hamilton, Te Ika a Maui / North Island, Aotearoa / New Zealand by the lead author, field work in the greater Waikato and Bay of Plenty and examination of herbarium specimens held at AK, CHR, WELT and UNITEC; herbarium acronyms follow Thiers (2008-continuously updated). With the exception of those measurements of stature and branch / branchlet widths, dimensions have been derived from dried material held in AK and UNITEC.

\section{Taxonomy}

Leptospermum repo de Lange \& L.M.H.Schmid sp. nov.

Type: AOTEAROA/ NEW ZEALAND, Te Ika a Maui / North Island, South Auckland, Waikato, Whangamarino, southern side of Island Block Road Bog. Latitude 37.312512 S, Longitude 175.13232358 E. Co-occurring species: Empodisma robustum Wagstaff \& B.R.Clarkson, Coprosma tenuicaulis Hook.f., Epacris pauciflora A.Rich., Salix cinerea L., Gleichenia dicarpa R.Br. and Schoenus brevifolius R.Br. (habitus - https://inaturalist. nz/observations/66458480). Holotype: P.J. de Lange 15000 \& T.J.P. de Lange, 12 Dec 2020, AK382940A (Fig. 2), AK382940B (Fig. 3), one specimen mounted on two herbarium sheets containing five parts of the same individual plant as follows: AK382940A - one flowering and one fruiting branch, two portions of branchlets showing bark, and AK382940B - one flowering branch. Isotypes: NSW, UNITEC 12809.

Illustrations: Figures 2-3. 


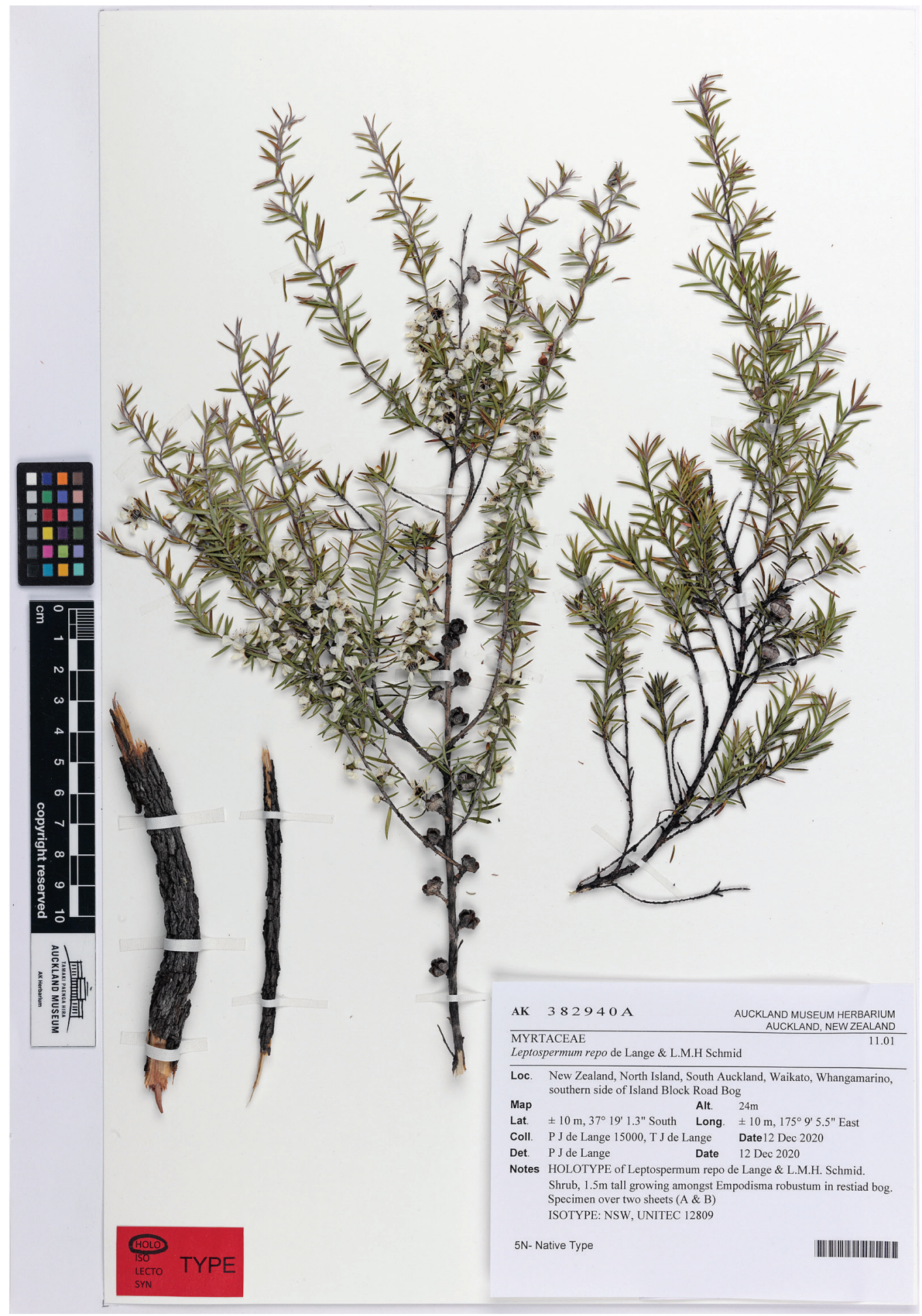

Fig. 2. Holotype of Leptospermum repo de Lange \& L.M.H.Schmid (AK382940A), specimen spread over two sheets AK382940A and AK382940B (Fig. 3) 


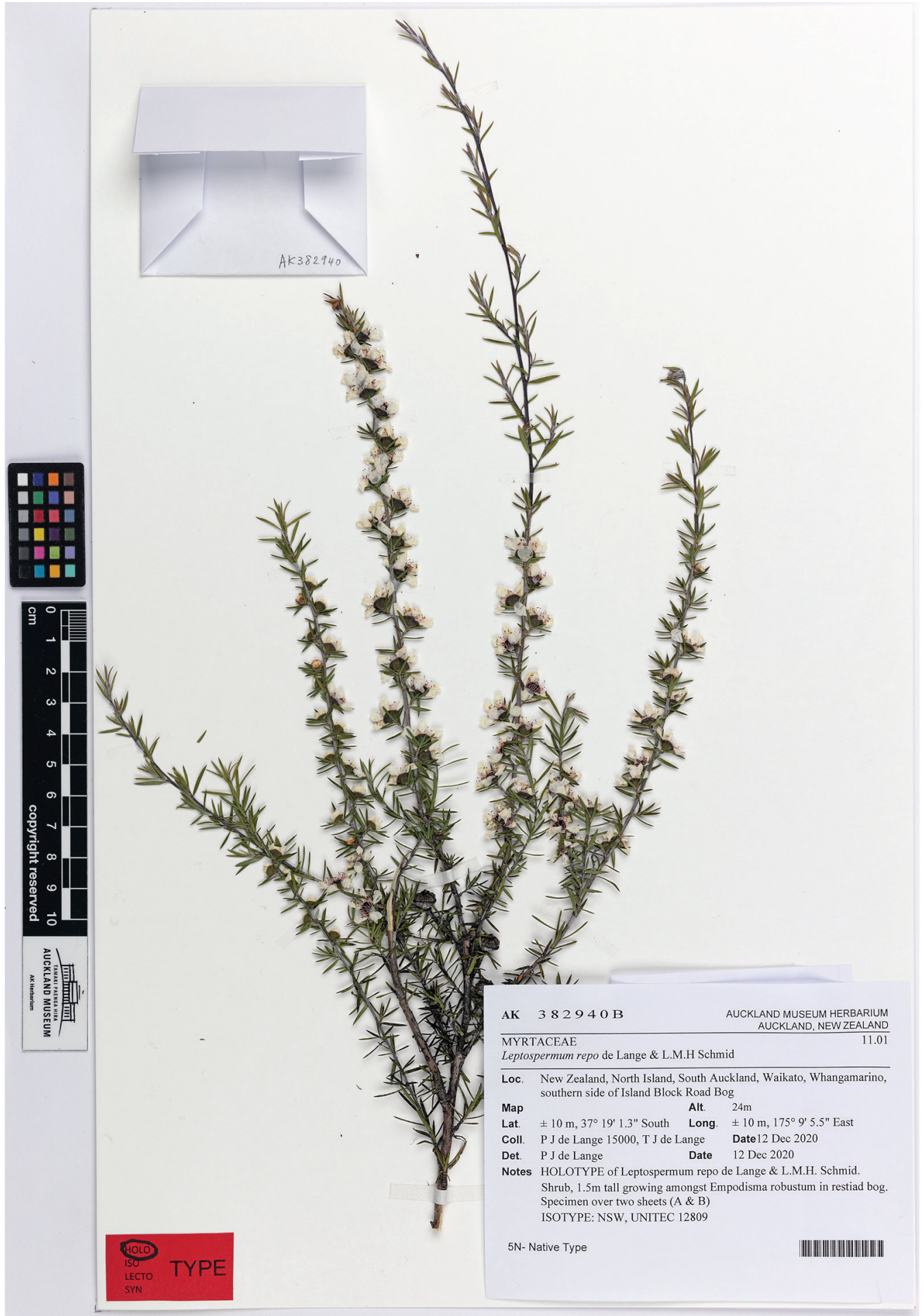

Fig. 3. Holotype of Leptospermum repo de Lange \& L.M.H.Schmid (AK382940B), specimen spread over two sheets AK382940A (Fig. 2) and AK382940B 
Diagnosis: Distinguished from Leptospermum scoparium $\mathrm{s}$. str. by the gracile, spindly, open-branched growth habit; widely divergent, longer, linear, linearlanceolate (rarely filiform), shortly cuspidate leaves; white petals, stamens mostly with white filaments (very rarely tinged pink near base), style and stigma usually green (very rarely pink); and by its restriction to peat bog habitats.

Growth habit - [Fig. 4, A-E] Shrub to small tree (1-) $3(-6) \mathrm{m}$ tall, sometimes much reduced in extreme acid wetlands, then attaining heights of $100 \mathrm{~mm}$ or less. Trunk - usually unbranched at base, up to $0.1 \mathrm{~m}$ d.b.h, usually devoid of branches in lower $1 / 3$ to $1 / 2$. Bark - firmly attached, fibrous, often deeply fissured. Branches - usually 3 or more, and openly branching with semi-erect to widely spreading branches, young stems copiously covered in $(0.12-0.24) 0.48(-0.80)$ $\mathrm{mm}$ long, white, straight to slightly flexuous, sericeous, antrorse-appressed hairs, becoming glabrescent with age. Vegetative buds $-3-8$, mostly shedding soon after vegetative growth commences, rarely with a few persistent, $(0.4-) 0.6-0.8(-1.0) \times(0.3-) 0.5-0.7(-0.9)$ $\mathrm{mm}$, amber to red-brown, scarious, oblong to ovoid, inner surface smooth, glossy, outer with frayed, lacerate margins or entire, basal portion densely invested in white antrorse-appressed to suberect sericeous hairs up to $0.01 \mathrm{~mm}$ long. Leaves - pleasantly spicy-scented when crushed, divergent to spreading, (5.0-) 8.0-11.0 (-15.0) $\times(0.3-) 0.5-0.8(-2.0) \mathrm{mm}$, glossy yellow-green, green to dark green; lamina linear, linear-lanceolate, narrowly lanceolate, occasionally filiform, flat to weakly concave, acute, minutely cuspidate, bases narrowly cuneate, margins minutely denticulate; surfaces sericeous hairy near base and along midrib, and proximal $1 / 3$ of leaf margin, glabrescent with hairs \pm persisting on basal portion of leaf and; oil glands numerous, more evident when dry. Perules $-4-6$, shedding at bud burst, $(0.4-)$ 0.6-0.8 (-1.0) × $(0.4-)$ 0.6-0.8 $(-0.9) \mathrm{mm}$, glabrous, hyaline, amber to pale red-brown, scarious, orbicular, margins usually entire, sometimes frayed inner surface smooth, glossy. Inflorescence - monadic on short axillary brachyblasts, or, on occasion on long, $200 \mathrm{~mm}$ long or more, terminal shoots. Prophylls - caducous, 2, 0.1-0.2 $\mathrm{mm}$ long, oblong, midrib scarcely developed, yellowgreen, green to red-green when fresh, tan when dry, abaxial surface densely invested in white sericeous hairs. Pedicels - sessile, or $0.1 \mathrm{~mm}$ long at anthesis, elongating to $2.4 \mathrm{~mm}$ after anthesis, terete, sparsely invested with antrorse-appressed, sericeous white hairs. Flower buds clavate, tholiform with calyx lobes not meeting. Fresh flowers when fully expanded 10-11 $(-15) \mathrm{mm}$ in diameter. Hypanthium - (2.8-) $3.0(-4.0) \times\left(1.6^{-}\right) 2.2(-4.0) \mathrm{mm}$, green or honey-brown, obconic, obconic-funnelform. Terminating in a slightly thicker rim bearing five calyx lobes; surface smooth (wrinkling in dry specimens) finely glandular punctate, glabrous. Calyx lobes 5, spreading, 2.4-2.6 × 2.4-2.6 mm, caducous, broadly deltoid with rounded apices, usually glabrous except for margins which may be sparsely ciliate, oil glands colourless. Receptacle dark red at anthesis. Petals -5 , spreading, 4-5 $\times 2-3 \mathrm{~mm}$, white, orbicular, apex obtuse to rotund, margins finely crimped, oil glands not evident. Stamens - (15-36, in 1-2 weakly defined whorls adnate to receptacular rim, filaments white. Antipetalous stamens $3(+2)$, antisepalous 4-6. Outermost antipetalous stamens erect or weakly incurved, on filaments $1.20-1.68 \mathrm{~mm}$ long, occasional inner whorl of 2 stamens present, these erect or incurved, $0.9-1.2 \mathrm{~mm}$ long, positioned at base of the outermost antipetalous pair. Antisepalous stamens about half length of antipetalous, on filaments $0.6-0.84$ $\mathrm{mm}$ long, incurved, erect or in mixtures of both. Anthers dorsifixed $0.36 \times 0.12 \mathrm{~mm}$, ovoid, latrorse. Pollen white to cream. Anther connective gland $0.24 \mathrm{~mm}$ long, amber, narrowly obovoid. Ovary - 5-locular, each loculus with c. 80 ovules, set in 8 rows on each placental lobe. Style (0.96-) 1.9-2.0 $\mathrm{mm}$ long at anthesis, elongating to $3 \mathrm{~mm}$ after anthesis, green (very rarely pink - one population); stigma $0.70-0.78 \mathrm{~mm}$ in diameter at anthesis, expanding to $0.9 \mathrm{~mm}$ following anthesis, flat, green, sometimes flushing pink at anthesis, finely papillate rugulose. Fruits - persistent, woody, (5-) $8(-9) \times\left(5^{-}\right) 6 \mathrm{~mm}$, pale brown-grey to grey, hemispherical / globose (sometimes broadly obconic), centre often with persistent style remnant, valves 5, exserted as a dome, indented at centre, \pm symmetrical with base. Valves opening on dead branches or following fire. Seeds - 2.3-2.4 (-2.6) $\times$ $0.24-0.24 \mathrm{~mm}$, linear, linear-cuneiform, curved, flexuous to sigmoid, laterally compressed or terete, 2-4-angled, apex truncate or acute, testa dull or glossy, orange-brown, glabrous, longitudinally striate.

Representative Specimens. Aotearoa / New Zealand. Coromandel Peninsula, Whangamata, Whangamata Estuary, G. Don. s.n., 30 Sep 2004, AK339689; Waikato, Huntly Basin, Whangamarino Wetlands, Te Reao Arm, Island Block Road, P.J. de Lange 12401, 11 Dec 2014, AK355754; Waikato, Huntly Basin, Whangamarino Wetlands, southern side of Island Block, P.J. de Lange 14999, 12 Dec 2020, UNITEC 12634; Waikato, Huntly Basin, Whangamarino, Te Reao Arm, P.J. de Lange 5811, 27 Nov 2003, AK285238 (Duplicate: CHR); 

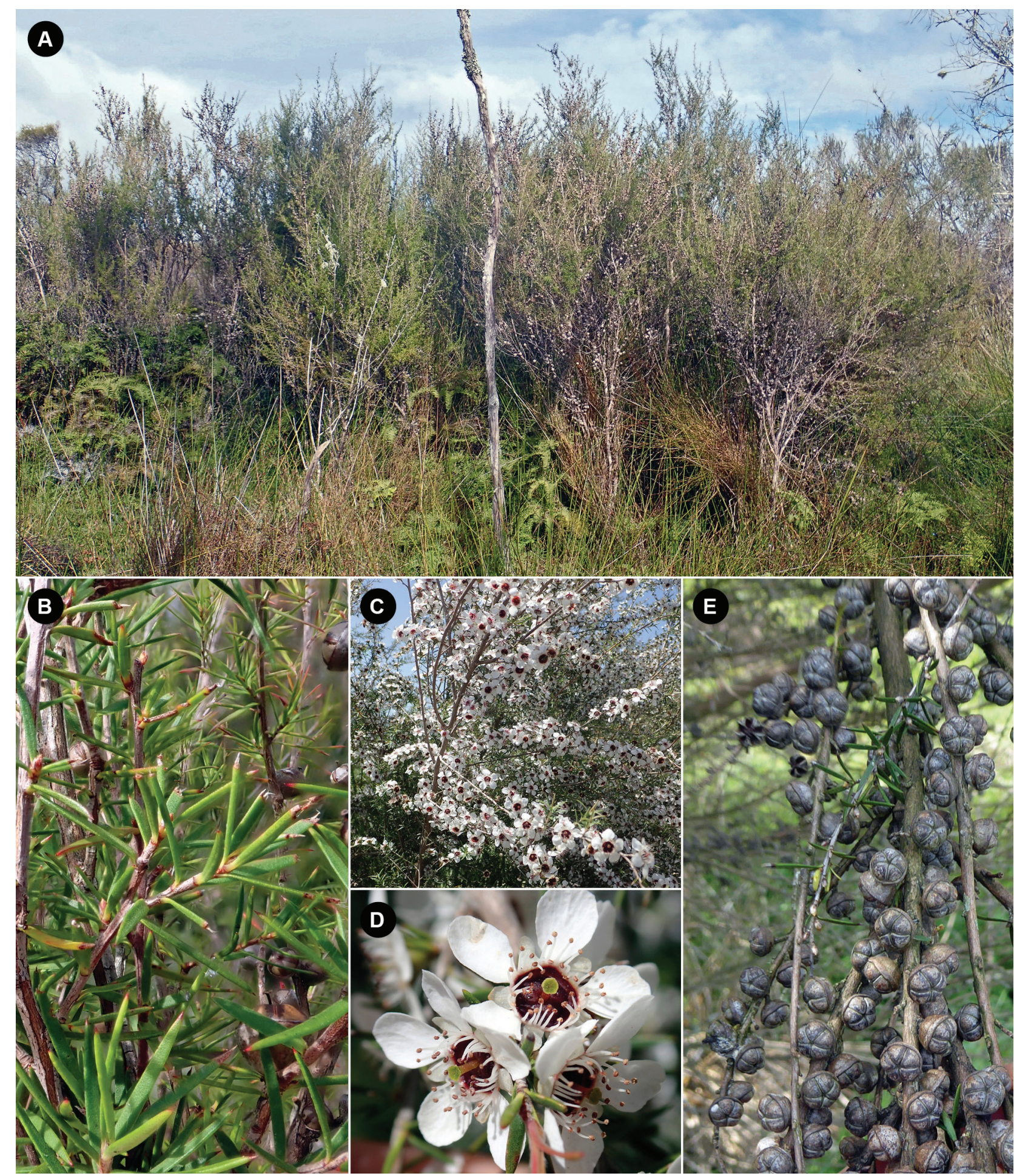

Fig. 4. Leptospermum repo de Lange \& L.M.H.Schmid. A: habitat within restiad bog, Kopouatai Peat Bog - the dominant shrub in this image is L. repo growing though an understorey of Gleichenia dicarpa (Gleicheniaceae), Schoenus brevifolius (Cyperaceae) and Empodisma robustum (Restionaceae). B: L. repo foliage, Kopouatai Peat Bog. C: Flowering branches, Kneebone Road, Te Mimiha Peat Bog. D: Flowers, Kneebone Road, Te Mimiha Peat Bog. E: Unopened, mature fruiting capsules, Valinitine Road, Komakorau Peat Bog (all images: P.J. de Lange) 
Waikato, Huntly Basin, Opuatia wetland, north of Lake Whangape, SE of "Lake Opuatia", E.K. Cameron 13218, 19 Nov 2005, AK294600; Waikato, Hauraki Plains, between Torehape \& Ngatea, Landcorp land, E.K. Cameron 11702, AK283564; Waikato, Hauraki Plains, Eastern side of Kopouatai Peat Bog, c.1.7 km west from the end of Canal Roads, E.K. Cameron 11771, 14 Sep 2003, AK284314; Waikato, Hauraki Plains, Kopouatai Peat Dome, Tee Canal Access, P.J. de Lange 6990 \& J.R. Rolfe, 17 Jul 2007, AK300200 (Duplicate: NSW); Waikato, Hauraki Plains, Kopouatai Peat Dome, Tee Canal Access, P.J. de Lange 15052 \& L .M.H. Schmid, 4 Apr 2021, UNITEC 12846 (Duplicate: AK, NSW); Waikato, Hamilton Basin, Te Hoe o Tainui Bog, northern outlet stream, P.J. de Lange 12400, 11 Dec 2014, AK355753; Waikato, Hamilton Basin, Hoe o Tainui Basin, Tainui Road above former Hoe o Tainui Peat Bog, P.J. de Lange 13223, 8 Oct 2016, AK362920 (Duplicate: NZFRI); Waikato, Hamilton Basin, Te Mimiha Peat Bog, Kneebone Road, P.J. de Lange 14980 \& T.J.P. de Lange, 5 Oct 2019, UNITEC 12421; Waikato, Hamilton Basin, Netherby, Orini Bog, P.J. de Lange 12399, 11 Dec 2014, AK355752; Waikato, Hamilton Basin, Komakorau Peat Bog, Valintine Road, P.J. de Lange 123198, 11 Dec 2014, AK355751 (Duplicates: CHR, NSW); Waikato, Hamilton Basin, Hamilton Basin, Komakorau (Motumaoho) Peat Bog, Woodlands Road, P.J. de Lange 13222, 8 Oct 2016, AK363436 (Duplicates: NZFRI, WELT); Waikato, Hamilton Basin, Komakorau Peat Bog, P.J. de Lange 14978 \& T.J.P. de Lange, 6 Jul 2019, UNITEC 12419 (Duplicate: AK); Waikato, Hamilton Basin, Hamilton, Claudelands, H.B. Matthews s.n., 10 Dec 1923, AK102058, 102057; Waikato, Hamilton Basin, McGregor Road, Rukuhia Peat Bog, P.J. de Lange 14891 \& T.J.P. de Lange, 10 Oct 2020, UNITEC 12422 (Duplicate: AK); Waikato, Kaimai Ranges, Tuahu (Killarney) Lakes, P.J. de Lange 15058 \& L.M.H. Schmid, 4 vi. 2021, UNITEC 12852 (Duplicate: AK); Waikato, Kaimai Range, Ngatamahinerua Plateau, north of Kauritatahi Hut, P.B. Cashmore s.n., M. Renner \& C. Bycroft, 22 Mar 2009, AK360761; Waikato, Hamilton Basin, Lake Serpentine (Southern Lake), P.J. de Lange s.n., 11 Dec 1989, AK191319 (Duplicate: WAIK); Waikato, Mamaku Forest, Waihou River, Lake Rotohoka, P.J. de Lange 6899, 16 Mar 2006, AK298498; Bay of Plenty, Waihi Estuary, E.K. Cameron 16090, 10 Jan 2013, AK336532; Bay of Plenty, Kaituna River, Kaituna Wetland, P.J. de Lange 13204 \& F.J.T. de Lange, 27 Sep 2016, AK362919 (NZFRI); Bay of Plenty (Rotorua Lakes), Lake Rotoiti, Hinehopu, Hinehopu Mire, P.J. de Lange 6818, 13 Mar 2006, AK298001.
Distribution: Endemic to Te Ika a Maui / North Island of Aotearoa / New Zealand, where Leptospermum repo is known mainly from peat bogs, notably those dominated by the restiads Empodisma robustum and Sporadanthus ferrugineus de Lange, Heenan \& B.D.Clarkson in the Waikato lowlands (Hamilton and Huntly Basins and the lower Hauraki Plains) (Fig. 5). East of these stations there are sporadic occurrences in the wetlands of the Coromandel Peninsula (Matarangi, Whangamata), the Kaimai Range (Tuahu Lakes), the southern Mamaku Plateau (Lake Rotohoko), at Hinehopu Mire (Lake Rotoiti), and the Kaituna wetlands, Bay of Plenty (Fig. 5). With the exception of the Kaituna occurrence, which correlates to a remnant of a formerly much larger peat bog system, and possibly Hinehopu Mire, the Mamaku Plateau, Kaimai and Coromandel Peninsula occurrences are seen as outliers of a species otherwise consistently associated with restiad bogs of the greater Waikato and possibly, historically, the Bay of Plenty lowlands.

Etymology: The epithet "repo" is taken from Te Reo Māori (Māori Language) word for "swamp" (Ngata, 1993: 467; Ryan, 1995: 218); it refers to the wetland habitat in which this species usually grows.

Habitats and co-associated flora species: Leptospermum repo is now virtually confined to restiad peat bogs within the greater Waikato (Fig. 5). These bogs, formerly exceeded 100000 ha in extent (Davoren et al., 1978; de Lange et al., 1999) and outside the Waikato were well developed in the far north of Northland around Kaitaia and Te Aupouri, near Whangarei (Hikurangi Swamp) and also in the lowlands of the Bay of Plenty between and presence of suitable habitat in Northland, there are no known observations or herbarium specimens of Leptospermum repo from this region.

Within this species stronghold, the restiad bogs of the Waikato lowlands, Leptospermum repo is a key woody shrub to small tree component of both low and high moor bogs. In these habitats, $L$. repo extends from the lag zone towards the bog centre (Fig. 4, A), reaching its greatest abundance between the lag and the upper rand of the high moor peat bogs. Within low moor systems, L. repo is found virtually throughout, including the fringes of peat lakes and sites frequently flooded either from associated water courses or during periods of high rainfall.

In these habitats Leptospermum repo is commonly associated with the following species: within the lag zone - Carex secta Boott, C. maorica Hamlin, C. virgata Sol. ex Boott, Machaerina rubiginosa (Spreng.) T.Koyama, M. tenax (Hook.f.) T.Koyama, M. teretifolia 


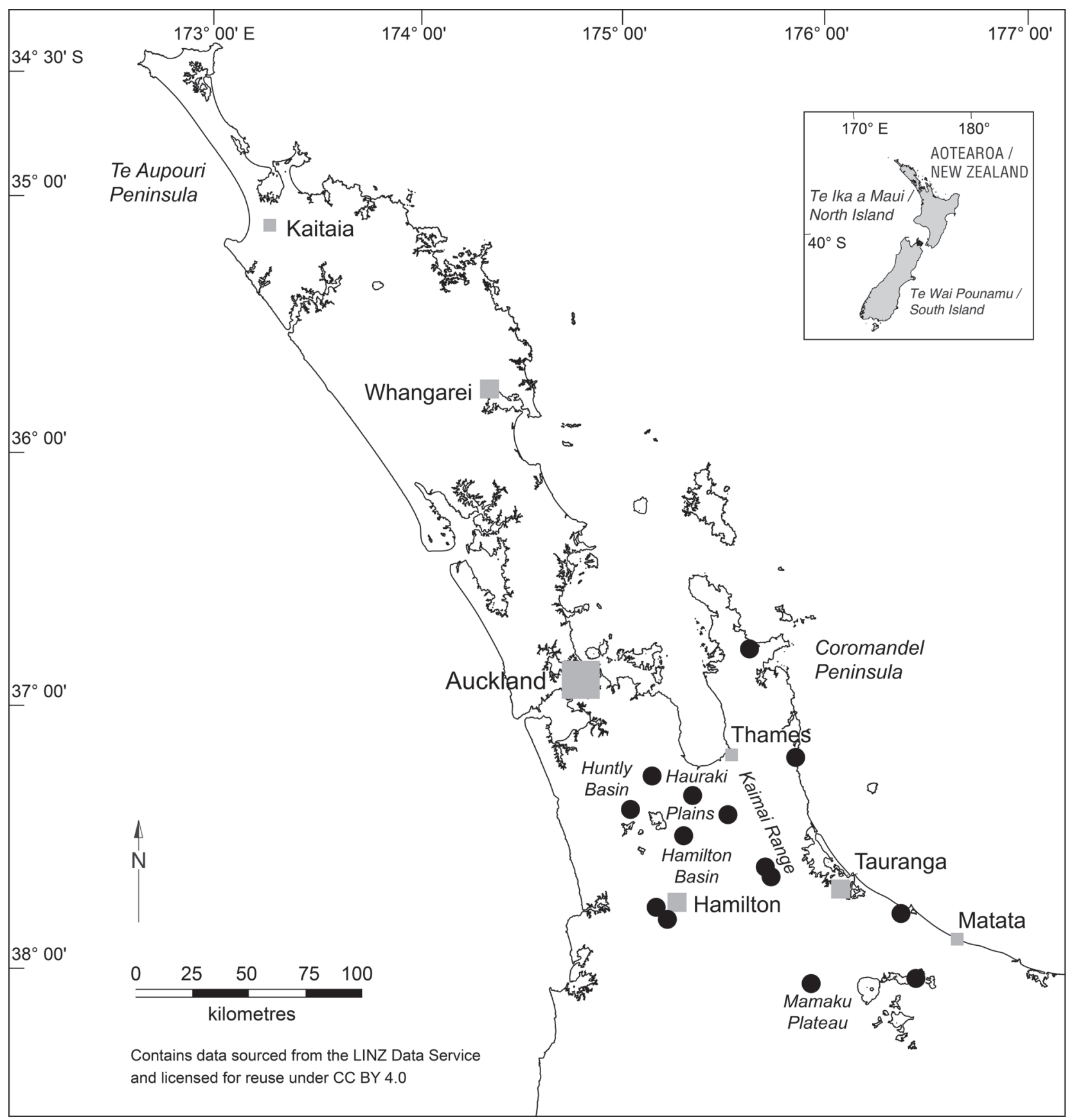

Fig. 5. Distribution of Leptospermum repo (black circles) which is confined to the northern portion of Te Ika a Maui / North Island of Aotearoa / New Zealand

(R.Br.) T.Koyama, Empodisma robustum, Coprosma propinqua A.Cunn. var. propinqua, C. tenuicaulis, Salix cinerea, Gleichenia dicarpa, Hiya distans (Hook.) Brownsey \& Perrie, and Osmunda regalis L., and, on the rand, or within the inner bog - Empodisma robustum, Sporadanthus ferrugineus, Dracophyllum lessonianum
A.Rich., Epacris pauciflora, Schoenus brevifolius, Machaerina teretifolia, and Netrostylis capillaris (F.Muell.) R.L.Barrett, J.J.Bruhl \& K.L.Wilson.

Phenology: Leptospermum repo, unusually for the Aotearoa / New Zealand members of the L. scoparium complex, has a rather short flowering season. While 
sporadic flowering may occur throughout the year, this is very unusual. In this species flowering is mostly observed between October and January, peaking in late November through December, specimens often so heavily laden with bloom, that the foliage is almost completely obscured (Fig. 4, C). Andromonoecious flowers, first reported for New Zealand populations of Leptospermum scoparium s. 1. by Primack \& Lloyd (1980) are also present in L. repo, though we have seen insufficient bisexual and male flowers as yet to draw any conclusions about their frequency within $L$. repo populations, and whether there are any notable size differences between them, or indeed other members of the L. scoparium complex. Fruits develop over a period of several months, and in this species rarely open unless the supporting branchlet has died, such as when plants have been killed by fire. Due to this growth habit it is not uncommon to find unopened capsules holding viable seed, partially immersed in bark on the older branches and trunk. In common with other members of the Leptospermum scoparium complex, L. repo, is capable of flowering in extremely reduced states when stressed, for example with specimens of less than $50 \mathrm{~mm}$ tall, growing in open extremely acidic and/ or flooded peat, frequently flowering.

Affinities: Leptospermum repo belongs to the northern Te Ika a Maui / North Island clade of L. scoparium s. 1. (Buys et al., 2019; Koot et al. in sub.). Those plants (L. scoparium var. incanum, L. aff. scoparium (a), and $L$. aff. scoparium (b) (Figures 6-8)) differ from the type of Leptospermum scoparium by their consistently longer, lanceolate, elliptic-lanceolate to linear leaves, larger, often more highly coloured flowers, and larger, often globose capsules. Within the northern Te Ika a Maui / North Island clade, Leptospermum repo is ecologically partitioned from the other associated Leptospermum scoparium taxa ( $L$. scoparium var. incanum, $L$. aff. scoparium (a), and $L$. aff. scoparium (b)) by its restriction to peat bog habitats, especially those dominated by Empodisma robustum and/or Sporadanthus ferrugineus. Morphologically the plants differ from the other allied L. scoparium in the northern Te Ika a Maui / North Island clade by their rather openly branched, spindly, gracile growth habit and by the widely divergent (mature leaves aligned $85^{\circ}-90^{\circ}$ to branchlet axis), distinctly finer, linear, linear-lanceolate, narrowly lanceolate, (occasionally filiform), minutely cuspidate leaves. The flowers of Leptospermum repo are also smaller than those in L. scoparium var. incanum and $L$. aff. scoparium (b), (10-11 (-15) mm cf. (18-) 20-25 mm in diameter), with the petals consistently white (never pink, or pink- tinged), and the stigma and style are green (very rarely pink), rather than dark brown-green, amber, pink or carmine. The stamen filaments of $L$. repo are for the most part white; at only one location, Matarangi, Whangapoua $\left(36.735622^{\circ} \mathrm{S} 175.647857^{\circ}\right.$ E) a few plants had occasional pink-tinged stamens. The stamen filaments of $L$. scoparium var. incanum and $L$. aff. scoparium (b) are usually pink-tinged or pink, very rarely completely white. From Leptospermum aff. scoparium (b), L. repo is also easily distinguished by its erect rather than decumbent to prostrate growth habit.

As far as is known Leptospermum repo is allopatric from populations of $L$. scoparium var. incanum and $L$. aff. scoparium (b). Throughout its range, Leptospermum repo is, however, broadly sympatric with $L$. aff. scoparium (a), and in a few places, such as Island Block Road and Falls Road, Whangamarino $\left(37.344970^{\circ} \mathrm{S}, 175.141959^{\circ} \mathrm{E}\right.$ and $37.346643^{\circ} \mathrm{S}, 175.183479^{\circ} \mathrm{E}$ respectively), and Tainui Road, Hoe-o-Tainui $\left(37.557858^{\circ}\right.$ S, $175.397995^{\circ}$ E) where the road skirts a series of low clay / tephra covered hills running along the margin of the peat bogs or where low-lying hills are exposed above the surrounding peat, both taxa can be found growing syntopically without any evidence of hybridisation.

Morphologically Leptospermum aff. scoparium (a) differs from $L$. repo by its more heavily branched growth habit and wider (4-6 mm c.f. $0.3-2.0 \mathrm{~mm}$ wide) lanceolate, elliptic-lanceolate, sharply acute, often distinctly cuspidate leaves. These when fully expanded are set at $60^{\circ}-80^{\circ}$ rather than $85^{\circ}-90^{\circ}$ to the branch axis, and due to their width, often obscure the branchlets internodes, such that the branchlets appear to be "leafier" than they actually are. This contrasts with finer, more divergent leaves of $L$. repo, whose positioning exposes the branchlets internodes, imparting the impression that this species has less leaves than it actually does. The mature leaves of Leptospermum aff. scoparium (a) are also more consistently hairy, along the leaf margins, midrib and particularly near the leaf base, whereas those of $L$. repo are glabrous or nearly so. The flowers of Leptospermum aff. scoparium (a) are usually larger than those of L. repo (up to $22 \mathrm{~mm}$ diameter, as compared to $15 \mathrm{~mm}$ in L. repo), and whilst usually white, may also be pink or pink-tinged. Another difference is that the stamen filaments of Leptospermum aff. scoparium (a) whilst often white, may be greenish or pink tinged, or on occasion completely pink, whilst the stigma and style mature brown-green, amber, pink or carmine, rather than uniformly green in L. repo. Finally, though more samples are needed ( $n=10$ per Leptospermum) Leptospermum 

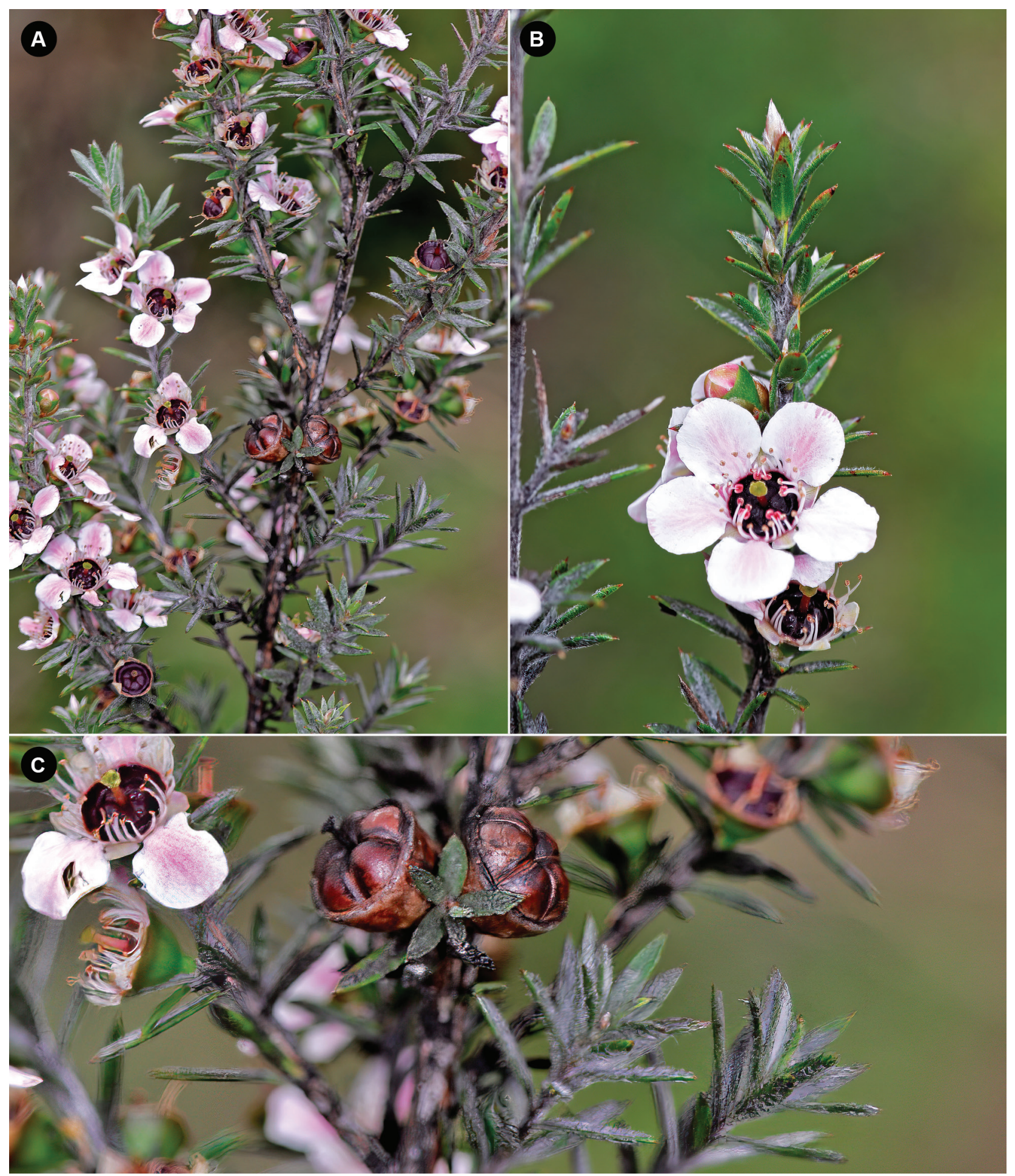

Fig. 6. Leptospermum scoparium var. incanum plant from Te Aupouri, Te Ika a Maui / North Island, Aotearoa / New Zealand. A: Foliage, flowers, immature and developing capsules, note the hairy leaves, which are a feature of this Leptospermum. B: Flower of $L$. scoparium var. incanum with pink-tinged petals (in this variety petals are sometimes completely pink (or even red) however, whiteflowered plants are also known). C: Immature and mature capsules (all images: J.R. Rolfe) 


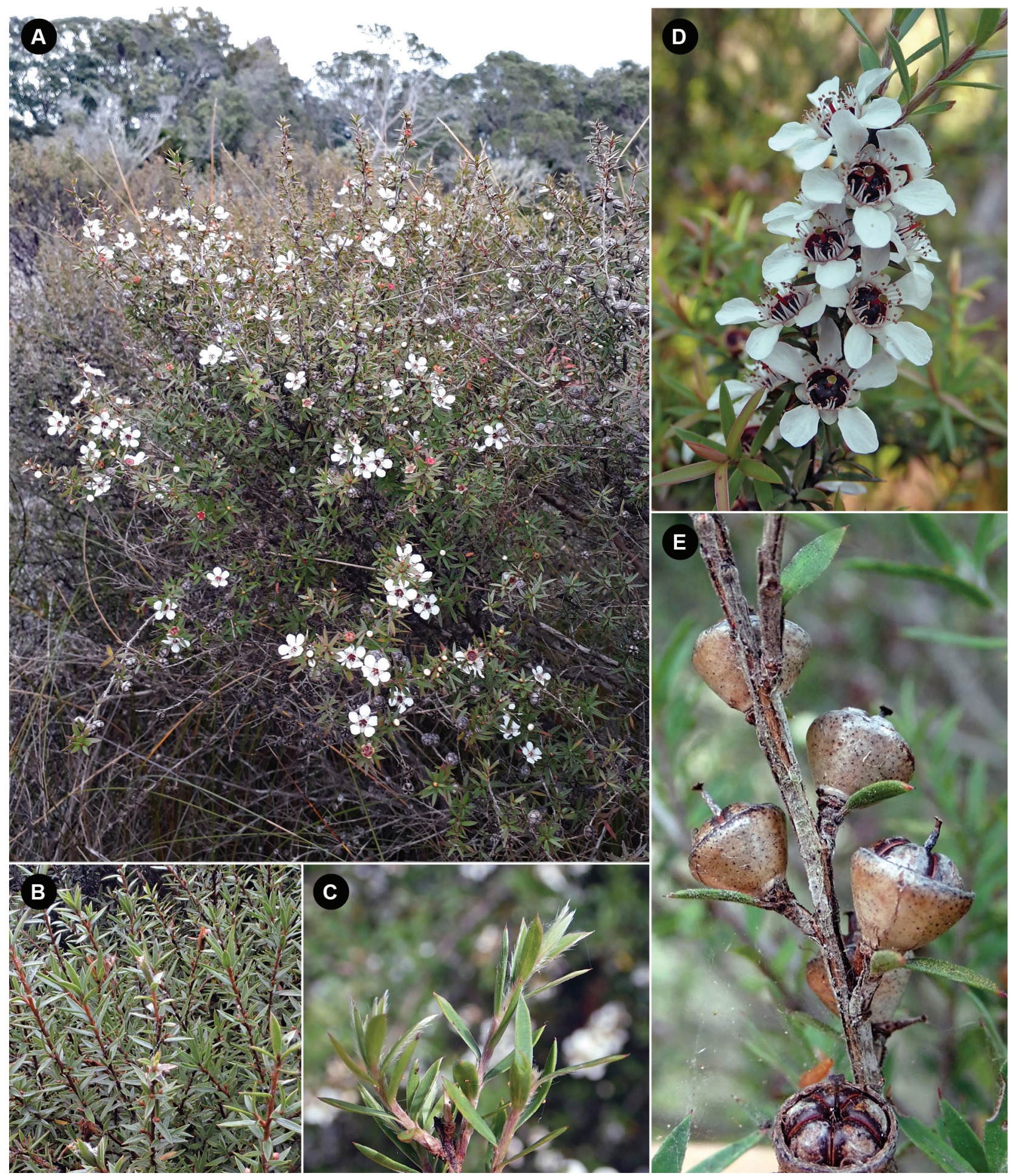

Fig. 7. Leptospermum aff. scoparium (a), a potentially distinct race allied to L. scoparium var. incanum with which it is broadly sympatric. This race is also sympatric with L. repo. A: Growth habit, gumland scrub, Whangateau Harbour, Te Ika a Maui / North Island. B: Foliage, Falls Road, Whangamarino, Te Ika a Maui / North Island. C: Close up of foliage, Mataia, Glorit, Kaipara, Te Ika a Maui / North Island. D: Flowers, Matarangi Loop Track, Matarangi, Coromandel Peninsula, Te Ika a Maui / North Island. E: Mature capsules, Miranda Back Road, Miranda, Te Ika a Maui / North Island (all images: P.J. de Lange) 

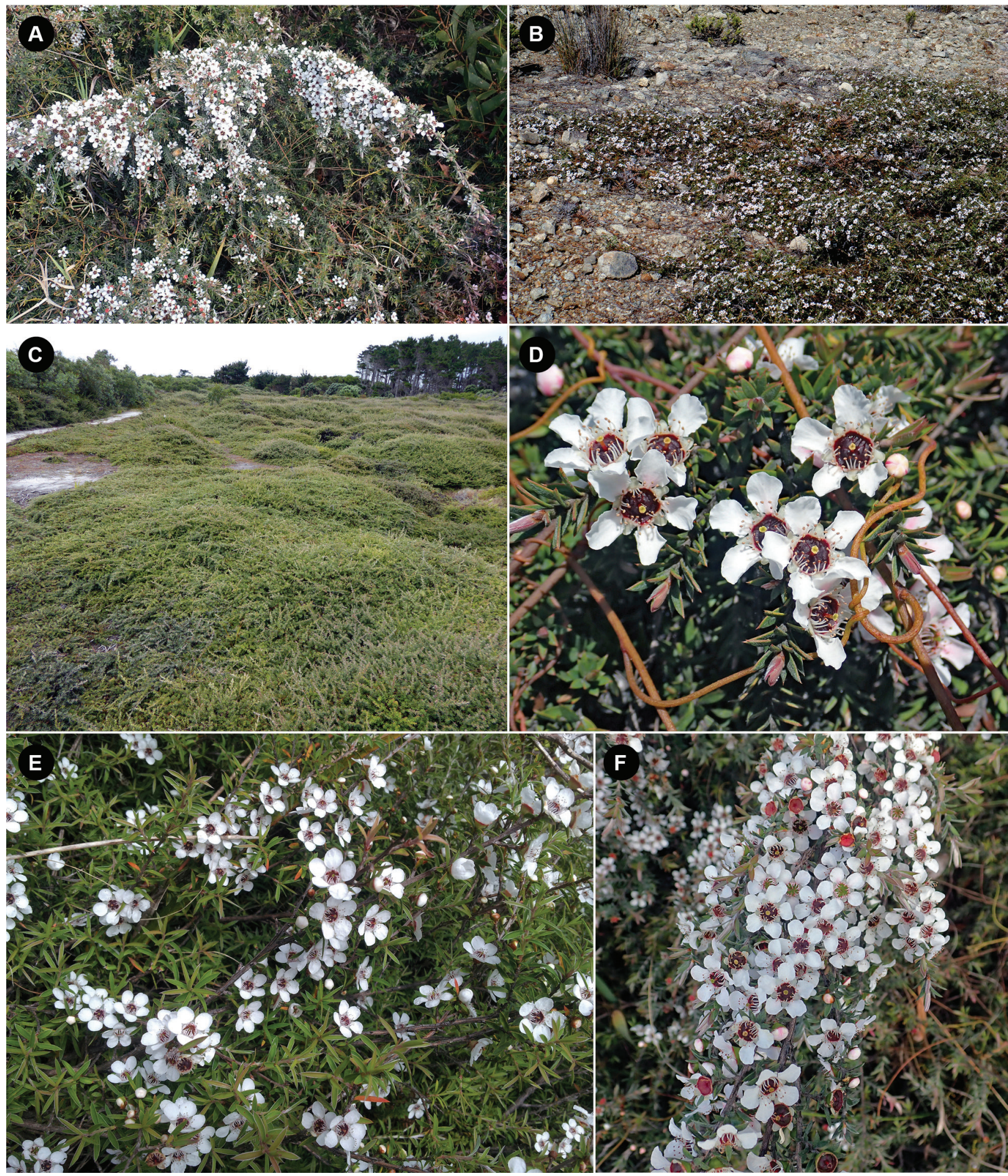

Fig. 8. Leptospermum aff. scoparium (b), a potentially distinct race allied to L. scoparium var. incanum and L. aff. scoparium (a), taxa with which it is broadly sympatric. This race is not known to be sympatric with L. repo. A: Flowering specimen growing on sandstone, Kauere Coast Track, Otaipango, Te Aupouri, Te Ika a Maui / North Island. B: Flowering specimen growing on ultramafic rock, North Cape, Te Paki, Te Ika a Maui / North Island. C: Growth habit at Kauere Coast Track, Otaipango, Te Aupouri, Te Ika a Maui / North Island. D: Close up of flowers Coast Track, Otaipango, Te Aupouri, Te Ika a Maui / North Island. E: Flowering branches, Maungaraho Rock, Tokatoka, Te Ika a Maui / North Island. F: Flowering branches Kauere Coast Track, Otaipango, Te Aupouri, Te Ika a Maui / North Island (all images: P.J. de Lange) 
repo capsules contain more seeds, (180-300 cf. 120-164 in $L$. aff. scoparium (a)).

From Leptospermum scoparium s. str., L. repo differs ecologically by its restriction to peat bog habitats, and morphologically by its gracile growth habit; longer, finer, linear, linear-lanceolate leaves, and larger flowers which white petals, usually white stamen filaments and usually green style and stigma. Leptospermum scoparium s. str. has smaller flowers, which may have pink-tinged petals, usually pink-tinged or pink stamen filaments, and pinktinged, pink or carmine coloured style and stigma; the leaves of $L$. scoparium s. str. are broadly ovate, oval to orbicular and sharply acuminate (Fig. 9).

Conservation Status: Leptospermum repo, as Leptospermum aff. scoparium (c) (AK191319; "Waikato peat bog"), has been listed by de Lange et al. (2018) as "Threatened / Nationally Critical" qualified "DP [Data Poor]", "De [Designated']" using the New Zealand Threat Classification System (Townsend et al., 2008). This high threat status was triggered by the threat listing panel's decision to invoke criteria " $\mathrm{C}$ - population (irrespective of size or number of subpopulations) with a very high ongoing or predicted decline of $>70 \% "$ using the option to "Designate" a threat status. Designation is undertaken when a taxon does not necessarily meet all the necessary requirements but, in the panel's, consensus view a high threat listing is merited (Townsend et al., 2008).

This step was taken because of the perceived threat of myrtle rust disease, caused by the rust fungus Austropuccinia psidii (G.Winter) Beenken. This rust was first reported from Aotearoa / New Zealand in May 2017, after which it has spread rapidly throughout the North Island and northern South Island (Galbraith, Large, 2017; Beresford et al., 2018). At the time the threat listings for the New Zealand Vascular Floras were being finalised (May 2017) the detection of the rust was considered sufficient to review the threat status of all New Zealand Myrtaceae (see Introduction above). Leptospermum scoparium s. 1. was suspected of being susceptible on the basis of attacks on plants of this species cultivated in Australia (MPI n.d. https://www.myrtlerust.org.nz/ assets/Uploads/Suseptible-MR-Species.pdf - accessed 25 May 2021). Subsequent research has now confirmed that Leptospermum scoparium s. 1. is susceptible (Grant et al., 2020) though attacks on the Aotearoa / New Zealand members of this species complex are so far uncommon, outside cultivation (see https://inaturalist.nz/ taxa/549208-Austropuccinia-psidii - accessed 25 May 2021).
Whether or not the high threat listing allocated by de Lange et al. (2018) is appropriate still remains to be seen, particularly as Austropuccinia is still expanding its range and widening its host range in Aotearoa / New Zealand. Irrespective, the potential range of Leptospermum repo through peat bog clearance and drainage has shrunk from an estimated 100000 ha to c. 10000 ha $(10 \%$ of its former range) in less than 100 years. Further throughout the lowlands of the Bay of Plenty and the Coromandel Peninsula, the species is now functionally extinct. Within the Hamilton Basin, the species is been lost from $90 \%$ of its former range and of the existing remnants most are likely to disappear through ongoing drainage and land clearance within the next decade.

In the interim then, pending the next national threat listing of the Aotearoa / New Zealand indigenous vascular flora (due 2022), cognisant of the ongoing spread of Austropuccinia psidii, we see no reason to contest the current threat status, beyond adjustment to the new species name formalised here.

Currently, Leptospermum repo remains secure as a functional species only within the Whangamarino and Opuatia wetlands of the Huntly Basin; the Torehape and Kopouatai Peat Bogs of the Hauraki Plains, and in those small remnants that persist around the peat lakes of the Hamilton Basin. The scattered occurrences in the Kaimai, Mamaku Ranges and Hinehopu mire, often of fewer than 10 individuals contribute little to the species' long term conservation security.

\section{Acknowledgements}

We thank Jeremy Rolfe (formerly of the New Zealand Department of Conservation) for supporting the concept of a revision of the Aotearoa / New Zealand Leptospermum scoparium complex, and lobbying for funding the revision. Finn de Lange, Theodore de Lange, Rhys O. Gardner assisted with field collection. We thank Ewen Cameron, Yumiko Baba, Dhahara Ranatunga for assistance with herbarium specimens in the Auckland Museum Herbarium (AK) and beyond. Jeremy Rolfe kindly prepared the maps and image plates for this paper, as well as supplying images of Leptospermum scoparium var. incanum. The thoughtful review of three anonymous referees helped improve this paper. 


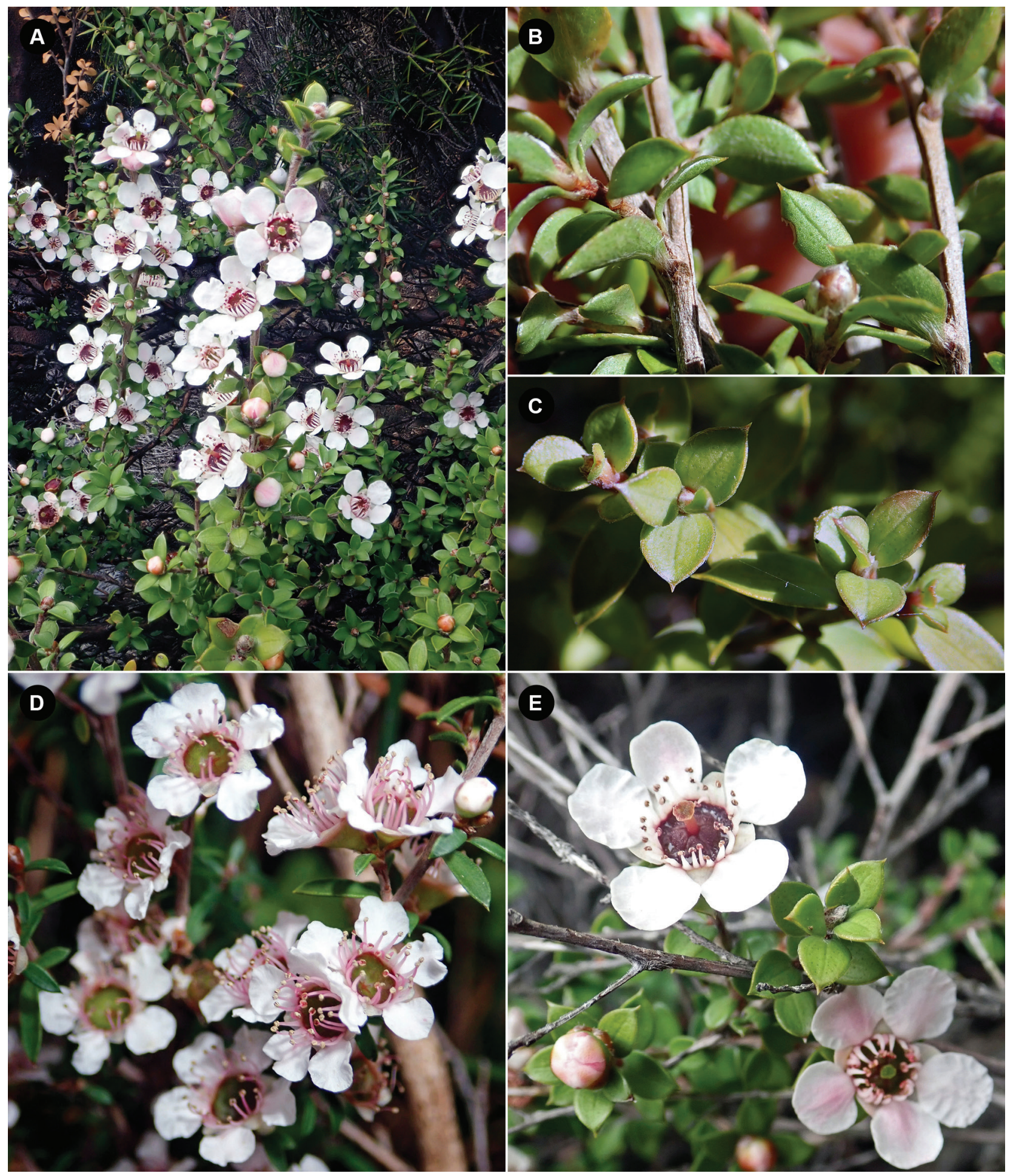

Fig. 9. Leptospermum scoparium s. str. A: Andromonecious shrub with bisexual and male flowers in coastal shrubland, Motupohue (Bluff Hill), Southland, Te Waipounamu / South Island. B \& C: leaves Motupohue (Bluff Hill), Southland, Te Waipounamu / South Island. D: Male flowers, Monument Hill, Waitangi West, Rekohu / Chatham Island, Chatham Islands. E: Bisexual flowers, Motupohue (Bluff Hill), Southland, Te Waipounamu / South Island (all images: P.J. de Lange) 


\section{References}

Aiton W. 1789. Hortus Kewensis; or, A catalogue of the plants cultivated in the Royal Botanic Garden at Kew, vol. 2. London: George Nicol, 460 pp.

Aiton W.T. 1811. Hortus Kewensis; or, A catalogue of the plants cultivated in the Royal Botanic Garden at Kew, vol. 3, ed. 2. London: Longman, Hurst, Rees, Orme, and Brown, $432 \mathrm{pp}$.

Allan H.H. 1961. Flora of New Zealand, vol. 1. Wellington: P.D. Hasselberg, Government Printer, liv + 1083 pp.

Bean A. 1992. The genus Leptospermum Forst. et Forst. F. (Myrtaceae) in northern Australia and Malesia. Austrobaileya, 3: 643-659.

Bean A. 2004. Three new species of Leptospermum (Myrtaceae) from Queensland and northern New South Wales. Telopea, 10: 831-838.

Beresford R.M., Turner R., Tait A., Paul V., Macara G., Yu Z.D., Martin R. 2018. Predicting the climatic risk of myrtle rust during its first year in New Zealand. Rust Pathogens, 71: 332-347. https://doi.org/10.30843/ nzpp.2018.71.176

Buys M.H., Winkworth R.C., de Lange P.J., Wilson P.G., Mitchell N., Lemmon A.R., Moriarty-Lemmon E., Holland S., Cherry J.R., Klápště J. 2019. The phylogenomics of diversification on an island: applying anchored hybrid enrichment to New Zealand Leptospermum scoparium (Myrtaceae). Botanical Journal of the Linnean Society, 191(1): 18-29. https://doi.org/10.1093/botlinnean/ boz026

Cheeseman T.F. 1906. Manual of the New Zealand Flora. $1^{\text {st }}$ ed. Wellington: Government Printer. 1199 pp. https://doi. org/10.5962/bhl.title. 12003

Cheeseman T.F. 1925. Manual of the New Zealand Flora. $2^{\text {nd }}$ ed. Wellington: Government Printer, 1163 pp.

Cockayne L. 1917a. Notes on New Zealand floristic botany, including descriptions of new species, \& c. (No. 2). Transactions and Proceedings of the New Zealand Institute, 49 [volume of 1916]: 56-65.

Cockayne L. 1917b. A consideration of the term "species" and "variety" as used in botany with special reference to the Flora of New Zealand. Transactions and Proceedings of the New Zealand Institute, 49 [volume of 1916]: 66-79.

Cockayne L. 1919. New Zealand plants and their story. Ed. 2. Wellington: Government Printer, 248 pp.

Cockayne L. 1926. Donald Petrie 1846-1925. Transactions and Proceedings of the Royal Society of New Zealand Institute, 56: 8-10.

Dawson M. 1997a. A history of Leptospermum scoparium in cultivation - discoveries from the wild. The New Plantsman, 4: 51-59.

Dawson M. 1997b. A history of Leptospermum scoparium in cultivation - garden selections. The New Plantsman, 4: 67-78.

Davoren A., McCraw J.D., Thompson K. 1978. A survey of New Zealand peat resources. In: Water and Soil Technical
Publication 14. Wellington: National Water and Soil Conservation Organisation, 128 pp.

de Lange P.J. 2019. The ongoing slide to extinction of the enigmatic Chatham Island linen flax (Linum monogynum var. chathamicum). Trilepidea, 190: 3-7.

de Lange P.J., Heenan P.B., Clarkson B.D., Clarkson B.R. 1999. Taxonomy, ecology, and conservation of Sporadanthus (Restionaceae) in New Zealand. New Zealand Journal of Botany, 37(3): 413-431. https://doi.org/10.1080/002882 $\underline{\text { 5X.1999.9512645 }}$

de Lange P.J., Rolfe J.R., Barkla J.W., Courtney S.P., Champion P.D., Perrie L.R., Beadel S.M., Ford K.A., Breitwieser I., Schönberger I., Hindmarsh-Walls R., Heenan P.B., Ladley K. 2018. Conservation status of New Zealand indigenous vascular plants, 2017. New Zealand Threat Classification Series, 22: 1-82.

Forster J.R., Forster G. 1776. Characteres generum plantarum, quas in itinere ad insulas maris Australis, collegerunt, descripserunt, delinearunt, annis MDCCLXXIIMDCCLXXV [1772-1775]. 2nd ed. London: B. White, T. Cadell, \& P. Emsly, x + viii + 150 pp. +75 tab. https:// doi.org/10.5962/bhl.title.4448

Galbraith M.P., Large M.F. 2017. Implications for selected indigenous fauna of Tiritiri Matangi of the establishment of Austropuccinia psidii (G. Winter) Beenken (myrtle rust) in northern New Zealand. Perspectives in Biosecurity, 2: 6-26.

Grant R., Smith G.R., Ganley B.J., Chagné D., Nadarajan J., Pathirana R.N., Ryan J., Arnst E.A., Sutherland R., Soewarto J., Houliston G., Marsn A.T., Koot E., Carnegie A.J., Menzies T., Lee D.J., Shuey L.S., Pegg G.S. 2020. Resistance of New Zealand Provenance Leptospermum scoparium, Kunzea robusta, Kunzea linearis, and Metrosideros excelsa to Austropuccinia psidii. Plant Disease, 104(6): 1771-1780. https://doi. org/10.1094/PDIS-11-19-2302-RE

Hooker J.D. 1853. The botany of the Antarctic voyage of H.M. discovery ships Erebus and Terror, in the years 1839-1843, under the command of Captain Sir James Clark Ross. Vol. 2. Flora Novae-Zelandiae. Part 1. Flowering plants. London: Lovell Reeve, xxxix + 312 pp. + LXX [70] tab.

Hooker J.D. 1867. Handbook of the New Zealand Flora: A systematic description of the native plants of New Zealand and the Chatham, Kermadec's, Lord Auckland's, and Macquarrie's islands. Part I. London: Reeve \& Co., lxviii + 798 pp. https://doi.org/10.5962/bhl.title.132966

Koot E., Arnst E., Taane M., Goldsmith K., Dormont E., Hancox T., Delaporte K., Thrimawithana A., Reihana K., González-Martínez S.C., Goldsmith V., Houliston G., Chagné D. (submitted, preprint). Genome-wide patterns of genetic diversity, population structure and demographic history in mānuka (Leptospermum scoparium) grown on indigenous Māori land. Molecular Ecology. https://doi. org/10.22541/au.161912114.47713005/v2

Kirk T. 1899. The students' flora of New Zealand and the outlying islands. Wellington: John Mackay, Government Printer, vi + 408 pp. https://doi.org/10.5962/bhl.title.54373 
Lyne A. 1993. Leptospermum namadgiensis (Myrtaceae), a new species from the Australian Capital Territory-New South Wales border area. Telopea, 5: 319-324.

Lyne A., Crisp M. 1996. Leptospermum jingera (MyrtaceaeLeptospermoideae): a new species from north-eastern Victoria. Australian Systematic Botany, 9: 301-306.

Metcalf L.J. 1972. The cultivation of New Zealand trees and shrubs. Wellington: A.H. \& A.W. Reed Ltd. 292 pp.

Metcalf L.J. 1993. The cultivation of New Zealand plants. Auckland: Godwit Press Ltd. 260 pp.

McDonald C.M., Keeling S.E., Brewer M.J., Hathaway S.C. 2018. Using chemical and DNA marker analysis to authenticate a high-value food, manuka honey. Science of Food, 2: Art. 9. https://doi.org/10.1038/ s41538-018-0016-6

Molan P. 1995. The antibacterial properties of honey. Chemistry in New Zealand, 59(4): 10-14.

Molan P.C., Russell K.M. 1988. Non-peroxide antibacterial activity in some New Zealand honeys. Journal of Apicultural Research, 27: 62-67.

Molan P.C., Smith I.M., Reid G.M. 1988. A comparison of the antibacterial activities of some New Zealand honeys. Journal of Apicultural Research, 27: 252-256.

Moore L.B. 1967. The Cockayne memorial lecture, 1965: Leonard Cockayne, botanist. Transactions of the Royal Society of New Zealand (General 2), 1: 1-18.

Ngata H.M. 1993. English - Māori Dictionary. Wellington: Ministry of Education, Learning Media Limited. 559 pp.

Perry N.B., Brennan N.J., Van Klink J.W., Harris W., Douglas M.H., McGimpsey J.A., Smallfield B.M., Anderson R.E. 1997. Essential oils from manuka and kanuka: Chemotaxonomy of Leptospermum. Phytochemistry, 44: 1485-1495.

Porter N.G., Smale P.E., Nelson M.A., Hay A.J., Van Klink J.W., Dean C.M. 1998. Variability in essential oil and plant morphology within a Leptospermum scoparium population. New Zealand Journal of Botany, 36: 125-133.

Primack R.B., Lloyd D.G. 1980. Andromonoecy in the New Zealand montane shrub manuka, Leptospermum scoparium (Myrtaceae). American Journal of Botany, 67: 361-368.

Ryan P.M. 1995. The Reed Dictionary of Modern Māori. Auckland: Reed Books, Reed Publishing (N.Z.) Ltd., 648 pp.

Sykes W.R. 2016. Flora of the Cook Islands. Hawai'i: National Tropical Botanical Garden, 973 pp.
Taunton E. 2021. Honey exports hit \$425m export sweet spot. Available at: www.stuff.co.nz. https://www.stuff.co.nz/ business/farming/124318150/honey-exports-hit-425mexport-sweet-spot (Accessed 14 June 2021).

Thiers B. 2008-onward. Index Herbariorum: A global directory of public herbaria and associated staff. New York Botanical Garden. Available at: http://sweetgum. nybg.org/science/ih (Accessed 11 June 2021)

Thompson J. 1989. A revision of the genus Leptospermum (Myrtaceae). Telopea, 3: 301-449.

Thomson A.D. 1983. The life and correspondence of Leonard Cockayne. Christchurch: DSIR Botany Division. 210 pp.

Thomson A.D. 1990. A comparison of the approach to taxonomic botany by T.F. Cheeseman and L. Cockayne. In: Short P. (ed.) History of systematic botany in AustralasiaProceedings of a symposium held at the University of Melbourne, 25-27 May 1988. Canberra: Australian Systematic Botany Society Inc., pp. 235-238.

Thomson A.D. 2021. 'Cockayne, Leonard', Dictionary of New Zealand Biography, first published in 1996. Te Arathe Encyclopedia of New Zealand. Available at: https:// teara.govt.nz/en/biographies/3c25/cockayne-leonard (Accessed 1 June 2021)

Townsend A.J., de Lange P.J., Duffy C.A.J., Miskelly C.M., Molloy J., Norton D.A. 2008. New Zealand Threat Classification System Manual. Wellington: Department of Conservation, 35 pp. Available at: https://www.doc.govt. nz/Documents/science-and-technical/sap244.pdf

Turland N.J., Wiersema J.H., Barrie F.R., Greuter W., Hawksworth D.L., Herendeen P.S., Knapp S., Kusber W.-H., Li D.-Z., Marhold K., May T.W., McNeill J., Monro A.M., Prado J., Price M.J., Smith G.F. 2018. International Code of Nomenclature for algae, fungi, and plants (Shenzhen Code) adopted by the Nineteenth International Botanical Congress, Shenzhen, China, July 2017. Regnum Vegetabile, 159: i-xxxviii + 1-254. https:// doi.org/10.12705/Code.2018

Webb C.J, Sykes W.R., Garnock-Jones P.J. 1988. Flora of New Zealand, vol. 4. Naturalized pteridophytes, gymnosperms, dicotyledons. Christchurch: Botany Division, D.S.I.R., $1365 \mathrm{pp}$.

Recommended for publication by S.L. Mosyakin 
де Ланге П.Дж., Шмід Л.М.Г. 2021. Leptospermum repo (Myrtaceae), новий вид із оселищ торфових боліт у північній Аотеароа / Новій Зеландії, відокремлений 3 групи Leptospermum scoparium s. I. Український ботанічний журнал, 78(4): 247-265 [In English].

Технічний університет УніТек, Окленд 1142, Нова Зеландія: П.Дж. де Ланге, Л.М.Г. Шмід.

Реферат. Описано новий вид Leptospermum repo de Lange \& L.M.H.Schmid sp. nov. (Myrtaceae), виокремлений 3 L. scoparium J.R.Forst. \& G.Forst. (sensu lato). Новий вид $є$ ендеміком торфових боліт Вайкато, регіон Бей-офПленті (Затока Достатку), та прилеглих східних хребтів північної частини Північного острова Нової Зеландії. Цей вид належить до новозеландської (Північний острів) клади у групі L. scoparium s. 1.; від інших представників цієї клади він морфологічно відрізняється витонченим, веретеноподібним, розгалуженим габітусом; лінійними, лінійно-ланцетними (рідше ниткоподібними), короткозагостреними, довшими листками, які широко розходяться; квітками з білими пелюстками, тичинками переважно з білими тичинковими нитками (дуже зрідка 3 рожевим відтінком біля основи), а також маточкою і приймочкою, які зазвичай є зеленими (дуже зрідка рожевими). Зараз Leptospermum repo трапляється на території близько 10\% колишніх оселищ, у яких, окрім кількох торфових боліт, що знаходяться під охороною, відбувається скорочення чисельності виду через втрату середовища його існування. Ще однією потенційною загрозою для L. repo віднедавна стала хвороба мирту, спричинена Austropuccinia psidii, адвентивним іржастим грибом, уперше виявленим в Аотеароа / Новій Зеландії в травні 2017 р. Ця іржа, 3 якою наразі немає засобів боротьби і запобігання загибелі інфікованих рослин, становить серйозну загрозу для видів родини Myrtaceae Аотеароа / Нової Зеландії. Оскільки через історичну втрату оселищ існує загроза скорочення багатьох популяцій L. repo, а також через потенційну загрозу з боку Austropuccinia psidii, у статті цілком підтримується запропонована Групою з природоохоронної оцінки судинних рослин природної флори Нової Зеландії оцінка цього виду (під попередньою назвою Leptospermum aff. scoparium (c) (AK191319; Waikato peat bog)) як такого, що перебуває "Під загрозою / Під національно критичною загрозою".

Ключові слова: Leptospermum, Leptospermum repo sp. nov., Leptospermum scoparium, Myrtaceae, Аотеароа / Нова Зеландія, новий вид, таксономія 


\title{
Nomenclatural and taxonomic comments on some taxa of Dysphania (Chenopodiaceae s. str. / Amaranthaceae s. l.)
}

\author{
Sergei L. MOSYAKIN* \\ M.G. Kholodny Institute of Botany, National Academy of Sciences of Ukraine, Tereschenkivska Str. 2, Kyiv 01601, Ukraine
}

\begin{abstract}
Following the comprehensive molecular phylogenetic results presented by Uotila et al. (2021), comments are provided on the infrageneric classification system of the genus Dysphania in its amended circumscription. Amendments and additions to the five-section scheme of Uotila et al. (2021) are proposed. In particular, the morphologically distinct lineage containing Dysphania atriplicifolia (earlier widely recognized in the monospecific genus Cycloloma as C. atriplicifolium) is recognized as a separate section, Dysphania sect. Cycloloma (Moq.) Mosyakin, comb. et stat. nov. Extensive synonymy of the section and its species is provided. The subclades revealed in the Australian clade of Dysphania sect. Dysphania are rather well characterized morphologically and were treated earlier as sections of either Chenopodium (sensu lato) or Dysphania. These subclades are recognized here as three subsections of sect. Dysphania: (1) subsect. Orthospora (R.Br.) Mosyakin, comb. et stat. nov.; (2) subsect. Dysphania; and (3) subsect. Tetrasepalae (Aellen) Mosyakin, comb. et stat. nov. The nomenclature of Dysphania graveolens (三 Chenopodium graveolens) is discussed. It is confirmed that the name Chenopodium graveolens was first validated not by Willdenow in 1809 but by Lagasca and Rodríguez in 1802. Original specimens associated with that name in both publications belong taxonomically to the same species currently known as D. graveolens (= Chenopodium incisum Poir.). In my opinion, Art. 41.8(a) of the ICN (Shenzhen Code) is directly applicable here. Consequently, the name D. graveolens should be cited with the corrected authorship "(Lag. \& Rodr.) Mosyakin \& Clemants", and the new combination in Dysphania based on Chenopodium incisum (provisionally cited in POWO as "Dysphania incisa (Poir.) ined.") is unnecessary.
\end{abstract}

Keywords: Chenopodium, Cycloloma, Dysphania, nomenclature, taxonomy

Article history. Submitted 17 July 2021. Revised 11 August 2021. Published 30 August 2021

Citation. Mosyakin S.L. 2021. Nomenclatural and taxonomic comments on some representatives of Dysphania (Chenopodiaceae s. str. / Amaranthaceae s. 1.). Ukrainian Botanical Journal, 78(4): 266-273. https://doi.org/10.15407/ ukrbotj78.04.266

*Corresponding author (e-mail: s_mosyakin@hotmail.com)

\section{Introduction}

Since the initial re-circumscription of Dysphania R.Br. (Chenopodiaceae s. str. / Amaranthaceae s. 1.; see Hernández-Ledesma et al., 2015; Morales-Briones et al., 2021) to include glandular-pubescent taxa earlier placed in Chenopodium L. sensu lato (see e.g., Mosyakin, Clemants, 2002, 2008; Clemants, Mosyakin, 2003 , etc.), several new and/or resurrected taxa have been added to the genus and further adjustments of the circumscription of Dysphania have been proposed (see Fuentes-Bazan et al., 2012a, b; Uotila, 2013; Uotila et al., 2021, and references therein). In particular, Teloxys aristata (L.) Moq. has been proved to be a member of the phylogenetically distinct genus Teloxys Moq. (MoquinTandon, 1834: 289), whereas Cycloloma Moq. (MoquinTandon, 1840: 17), the monospecific genus that contained C. atriplicifolium (Spreng.) J.M.Coult. (Coulter in Britton et al., 1894: 143), was revealed as phylogenetically nested in Dysphania near the clade corresponding to Dysphania sect. Adenois (Moq.) Mosyakin \& Clemants (2002: 382; see also Simón, 1996, 1997). In contrast, Australasian Rhagodia R.Br. and Einadia Raf. (Scott, 1978a; Wilson, 1983, 1984) were revealed as members

(C) 2021 S.L. Mosyakin. Published by the M.G. Kholodny Institute of Botany, NAS of Ukraine. This is an open access article under the terms of the Creative Commons Attribution License (http://creativecommons.org/licenses/by/4.0/), which permits use, distribution, and reproduction in any medium, provided the original work is properly cited 
of a re-circumscribed Chenopodium (see FuentesBazan et al., 2012a, b; Mosyakin, Iamonico, 2017, and references therein). In general, the infrageneric taxonomy of Dysphania is now rather well understood, but several morphologically deviant and geographically restricted taxa, in particular, D. stellata (S.Watson) Mosyakin \& Clemants from Mexico, the Central American taxon D. dissecta (Moq.) Mosyakin \& Clemants, and the South American D. minuata (Aellen) Mosyakin \& Clemants, currently remain unplaced to sections or clades (see Mosyakin, Clemants, 2008: 429; Uotila et al., 2021).

In the present article I provide additional comments on and adjustments to the infrageneric system of Dysphania, following the recent treatment of the genus by Uotila et al. (2021) and taking into consideration the earlier infrageneric classifications and taxonomic treatments (Aellen, 1930a, b; Scott, 1978b; Wilson, 1983, 1984; Mosyakin, Clemants, 2002, 2008, etc.), and also consider the nomenclatural case of Chenopodium graveolens, which affects the nomenclature of the species that was until recently accepted as Dysphania graveolens, with the authorship usually cited as "(Willd.) Mosyakin \& Clemants".

\section{On Cycloloma and its infrageneric placement in a re-circumscribed Dysphania}

The nomenclature and taxonomy of a morphologically very peculiar species until recently known mainly under the name Cycloloma atriplicifolium (Spreng.) J.M.Coult. (see Coulter in Britton et al., 1894; Standley, 1916; Mosyakin, 2003, and references therein) was haunted by many problems. When Moquin-Tandon decided to segregate that North American species in a genus of its own, he first considered the generic name Amoreuxia Moq. (a later homonym of Amoreuxia DC., now placed in Bixaceae, formerly Cochlospermaceae) and then, in 1834, described in detail the genus Cyclolepis Moq. (not mentioning the name Amoreuxia), but that name again turned to be a later homonym, this time of Cyclolepis Gillies ex D.Don (Asteraceae). Finally, the name Cycloloma Moq. was proposed in 1840 as the replacement name for the illegitimate generic name Cyclolepis Moq. (see Moquin-Tandon, 1834, 1840, 1849). Reichenbach $(1841: 153,236)$ also noticed the homonymy of Cyclolepis and proposed the replacement name Petermannia Rchb., but that name was published later than Cycloloma. The generic name Amorea was attributed by Delile (1844: 1) to Moquin-Tandon; however, Moquin-Tandon (1849) did not recognize his authorship of that name and instead attributed it to Delile only. Delile (1844) did not provide any description of the genus Amorea but his citation of "Amorea platyphylla Moquin" can be interpreted as indirect reference (Art. 38.14 and 41.3 of the ICN: Turland et al., 2018) to the name Cyclolepis platyphylla (Michx.) Moq. and MoquinTandon's description of Cyclolepis.

The only species of Cycloloma was placed by earlier authors in Salsola L. (Sprengel, 1801, etc.), Kochia Roth, or Chenopodium (see the nomenclatural citations below), in addition to the generic names mentioned above, and in synonymy below. Its placement in Salsola sensu lato or Kochia sensu lato was, undoubtedly, due to the presence of a transverse horizontal wing encircling the perianth. That wing is, however, only superficially similar to winglike appendages present on perianth segments in many taxa of Salsoloideae and Camphorosmoideae (see Kühn et al., 1993; Cabrera et al., 2009, 2011; Kadereit, Freitag, 2011, etc.) and its development is different. Because of that the placement of Cycloloma in Camphorosmeae (Scott, 1978c; Kühn et al., 1993) was not justified and, as I noted earlier (Mosyakin, 2003: 265), "Cycloloma is more closely related to Chenopodium in the broad sense; the problem of its proper placement requires additional study".

Recent molecular phylogenetic results (Uotila et al., 2021) demonstrated that Cycloloma is nested within the re-circumscribed genus Dysphania and is most probably sister to the large clade of American taxa recognized as Dysphania sect. Adenois (Moq.) Mosyakin \& Clemants (incl. Dysphania sect. Roubieva (Moq.) Mosyakin \& Clemants). The new nomenclatural combination Dysphania atriplicifolia (Spreng.) G.Kadereit, Sukhor. \& Uotila (in Uotila et al., 2021: 542) has been properly validated, based on these phylogenetic findings.

When providing my open review of the manuscript by Uotila et al. in 2020, I recommended the authors to recognize the Cycloloma lineage at the sectional or at least subsectional level, considering its phylogenetic position and the morphological distinctiveness ${ }^{1}$.

1 "I think that a separate section or at least subsection should be recognized for the former Cycloloma (one of possible new combinations: Dysphania sect. Cycloloma (Moq.) AUTHORS or Dysphania sect. Adenois (Moq.) Mosyakin \& Clemants subsect. Cycloloma (Moq.) AUTHORS). Its unique morphological characters (well described in the manuscript) and phylogenetic position as probably sister to the rest of taxa of that group are sufficient reasons for that. Also, recognition of subsections in Dysphania sect. Dysphania can be considered as well" (from my review of the manuscript; also, my email message of 22 July 2020 to Pertti Uotila). 
However, they preferred to place Dysphania atriplicifolia in sect. Adenois, thus stretching considerably the diagnostic morphological characters of the section to accommodate that morphologically deviant species. They, however, admitted that "it [D. atriplicifolia $]$ has unique morphological characters within the genus, which might allow to recognize a subsection for it. However, there are several American species, three of them morphologically distinctive, that were not included in our analysis, and due to lack of this information, no further division of $D$. sect. Adenois was adopted" (Uotila et al., 2021: 542). In my opinion, morphological characters of the former Cycloloma are too distant and dramatically different from those peculiar to Dysphania sect. Adenois: for example, (1) the connate perianth segments with a horizontal, membranous, circular wing, a unique feature of Cycloloma; (2) lax, almost leafless inflorescences with remote flowers/fruits in the Cycloloma lineage versus usually compact and dense linear inflorescences, or sometimes axillary clusters, in most of members of sect. Adenois (sensu stricto), (3) fruits in Cycloloma are larger than those in all members of sect. Adenois; (4) the tumbleweed life form in Cycloloma is not similar to the general plant architecture in most of taxa of sect. Adenois. Several other arguments can be added as well.

Dysphania R.Br. sect. Cycloloma (Moq.) Mosyakin, comb. et stat. nov.

Basionym: Cycloloma Moq., Chenop. Monogr. Enum.: 17 (1840).

Type: Cycloloma platyphyllum (Michx.) Moq., Chenop. Monogr. Enum.: 18 (1840).

= Amoreuxia Moq., Mem. Soc. Hist. Nat. Monsp. (1826) [non vidi], nom. illeg. (later homonym, Art. 53.1 of the ICN: Turland et al., 2018), non Amoreuxia DC., Prodr. 2: 638. 1825 (Bixaceae, formerly Cochlospermaceae).

ECyclolepis Moq., Ann. Sci. Nat., Bot. sér. 2, 1: 203 (1834), nom. illeg. (later homonym, Art. 53.1 of the ICN: Turland et al., 2018), non Cyclolepis Gillies ex D.Don, Philos. Mag. Ann. Chem. 11: 392 (1832) (Asteraceae).

$\equiv$ Petermannia Rchb., Deut. Bot. Herb.-Buch: 153 (1841).

$\equiv$ Amorea Delile, Index Seminum [Montpellier] [issue of 1844]: 1 (1844).

The section contains only one species:

Dysphania atriplicifolia (Spreng.) G.Kadereit, Sukhor. \& Uotila, Taxon 70(3): 542 (2021). $\equiv$ Salsola atriplicifolia Spreng., Erster Nachtr. Bot. Gart. Halle: 35, adnot. 46 (1801). $\equiv$ Kochia atriplicifolia (Spreng.) Roth, Neue Beytr. Bot. 1: 177 (1802). 三 Cycloloma atriplicifolium (Spreng.) J.M.Coult., Mem. Torrey Bot. Club 5: 143 (1894). 三 Chenopodium atriplicifolium (Spreng.) A.Ludw. ex Graebn., Syn. Mitteleur. Fl. 5(1, Lief. 79 \& 80): 18 (1913).

= Salsola platyphylla Michx., Fl. Bor.-Amer. 1: 174 (1803). $\equiv$ Amoreuxia platyphylla (Michx.) Moq., Mem. Soc. Hist. Nat. Monsp. (1826) [non vidi]. Cyclolepis platyphylla (Michx.) Moq., Ann. Sci. Nat., Bot. sér. 2, 1: 203 (1834). E Cycloloma platyphyllum (Michx.) Moq., Chenop. Monogr. Enum.: 18 (1840). $\equiv$ Amorea platyphylla (Michx.) Delile, Index Seminum [Montpellier] [issue of 1844]: 1 (1844).

= Kochia dentata Willd., Hort. Berol. 1(3): tab. 28 (1804). $\equiv$ Salsola dentata (Willd.) Germann, Verz. Pfl. Bot. Gart. Kais. Univ. Dorpat [vol. of 1807]: 116 (1807).

= Chenopodium radiatum Schrad., Neues J. Bot. 3(3): 85 (1809).

Invalid names under which the species was occasionally cultivated or mentioned in the $19^{\text {th }}$ century:

$=$ Salsola latifolia hort. ex Poir. in Lam., Encycl. 7: 298 (1806), nom. inval. (pro syn., Art. 36.1(b) of the ICN: Turland et al., 2018).

= Salsola chenopodioides hort. ex Dum.Cours., Bot. Cult., ed. 2, 2: 463 (1811), nom. inval. (pro syn.).

= Salsola corymbosa hort. ex Moq. in DC., Prodr. 13(2): 60 (1849), nom. inval. (pro syn.).

= Salsola paniculata hort. ex Moq. in DC., Prodr. 13(2): 60 (1849), nom. inval. (pro syn.).

= Salsola stellata hort. ex Moq. in DC., Prodr. 13(2): 60 (1849), nom. inval. (pro syn.).

\section{On Australian groups of Dysphania sect. Dysphania (as outlined in Uotila et al., 2021)}

The phylogenetic analysis of Uotila et al. (2021) revealed three main clades in the Australian group that they recognized as Dysphania sect. Dysphania. It is noteworthy that these clades quite well correspond to the main morphology-based groups, usually recognized earlier as infrageneric taxa (sections) of either Chenopodium or Dysphania.

In particular, (1) the clade containing Dysphania carinata (R.Br.) Mosyakin \& Clemants, D. cristata (R.Br.) Mosyakin \& Clemants, D. melanocarpa (J.M.Black) Mosyakin \& Clemants, D. pumilio (R.Br.) Mosyakin \& Clemants, and D. truncata (Paul G.Wilson) Mosyakin \& Clemants corresponds to Dysphania sect. Orthospora (R.Br.) Mosyakin \& Clemants (三 Chenopodium sect. 
Orthosporum R.Br.: see Brown, 1810: 407; Scott, 1978b; Wilson, 1983, 1984; Mosyakin, Clemants, 2002, 2008, and references therein); (2) the clade of D. glandulosa Paul G.Wilson, D. glomulifera (Nees) Paul G.Wilson, D. littoralis R.Br., D. platycarpa Paul G.Wilson, and D. valida Paul G.Wilson corresponds to Dysphania sect. Dysphania (see Scott, 1978b; Mosyakin, Clemants, 2002; Clemants, Mosyakin, 2003); and (3) the clade of D. congestiflora S.J.Dillon \& A.S.Markey, D. plantaginella F.Muell., D. simulans F.Muell. \& Tate ex Tate, and D. sphaerosperma Paul G.Wilson contains taxa placed earlier in Dysphania sect. Tetrasepalae (Aellen) A.J.Scott ( $\equiv$ Chenopodium sect. Tetrasepala Aellen) (see Aellen, 1930b: 490; Scott, 1978b: 218; Mosyakin, Clemants, 2002; Dillon, Markey, 2017), while its subclade containing D. rhadinostachya (F.Muell.) A.J.Scott and D. kalpari Paul G.Wilson includes taxa earlier placed in Dysphania sect. Caudatae A.J.Scott (Scott, 1978b: 218). We propose to recognize these three well-outlined groups (clades) as subsections of Dysphania sect. Dysphania.

Dysphania sect. Dysphania subsect. Dysphania (autonym, Arts. 22.3 and 32.3 of the ICN: Turland et al., 2018).

Type: Dyspania littoralis R.Br., Prodr. Fl. Nov. Holland.: 407 (1810), the only species originally included in Dysphania by Brown (1810: 407).

Dysphania sect. Dysphania subsect. Orthospora (R.Br.) Mosyakin, comb. et stat. nov.

Basionym: Chenopodium L. sect. Orthosporum R.Br., Prodr. Fl. Nov. Holland.: 407 (1810). 三 Dysphania R.Br. sect. Orthospora (R.Br.) Mosyakin \& Clemants, Ukrayins'k. Bot. Zhurn. 59(4): 382 (2002).

Type: Chenopodium cristatum R.Br. (see Wilson, 1983: 169; Uotila et al., 2021: 543).

Dysphania sect. Dysphania subsect. Tetrasepalae (Aellen) Mosyakin, comb. et stat. nov.

Basionym: Chenopodium L. sect. Tetrasepala Aellen, Bot. Jahrb. Syst. 63: 490 (1930). $\equiv$ Dysphania R.Br. sect. Tetrasepalae (Aellen) A.J.Scott, Bot. Jahrb. Syst. 100(2): 218 (1978).

Type: Dysphania inflata (Aellen) A.J.Scott $\equiv$ D. rhadinostachya (F.Muell.) A.J.Scott subsp. inflata (Aellen) Paul G.Wilson (Scott, 1978b: 218; Uotila et al., 2021: 543).

= Dysphania R.Br. sect. Caudatae A.J.Scott, Bot. Jahrb. Syst. 100(2): 218 (1978).

Type: Dysphania plantaginella F.Muell. (see Scott, 1978b: 218).
These subsections (clades as outlined in Uotila et al., 2021) of Dysphania sect. Dysphania can be distinguished using the following key:

1. Perianth segments (tepals) normally 5 subsect. Orthospora

- Perianth segments (tepals) normally 4-1 ............. 2

2. Perianth segments (tepals) 4-3. Inflorescences dense, spike-like, leafless or almost leafless subsect. Tetrasepala

- Perianth segments (tepals) 2-1. Inflorescences interrupted, consisting mostly of axillary clusters .subsect. Dysphania

\section{On Chenopodium graveolens}

It was usually assumed that the name Chenopodium graveolens was first published by Willdenow (1809: 290; IPNI, 2021-onward: https://www.ipni.org/n/56134-2). However, that name is a later homonym (or an isonym?) of the earlier name Chenopodium graveolens that has been published earlier by Lagasca and Rodríguez (1802: 70) (see IPNI, 2021-onward: https://www.ipni. org/n/164958-1). In the Plants Of the World Online online database (POWO, 2021-onward, accessed 9 June and 5 July 2021) the name Chenopodium graveolens Lag. \& Rodr. (http://www.plantsoftheworldonline.org/ taxon/urn:Isid:ipni.org:names:164958-1) was listed on 9 June 2021 as a synonym of D. schraderiana (Schult.) Mosyakin \& Clemants, but later (accessed 5 July 2021) it was listed as a synonym of "Dysphania incisa (Poir.) ined.".

The name Chenopodium graveolens Willd. (http:// www.plantsoftheworldonline.org/taxon/urn:lsid:ipni. org:names:56134-2) was listed on 9 June and 5 July 2021 as a synonym of the same provisional combination, "Dysphania incisa (Poir.) ined.".

Digital images of and associated data on at least two original (or presumably original) specimens of Chenopodium graveolens Lag. \& Rodr. are available online from JSTOR Global Plants (https://plants.jstor. org/). Images of specimens of C. graveolens associated with Willdenow are available from both the Willdenow Herbarium at B (Virtual Herbarium Berolinense; http:// ww2.bgbm.org/herbarium/default.cfm) and JSTOR Global Plants.

The specimen MA214007 (image and data are available from: $\quad$ https://plants.jstor.org/stable/10.5555/al.ap. specimen.ma214007) contains five large branches plus small fragments in an envelope, and has the presumably 
original handwritten label ("Chenopodium graveolens | Lagasca et Rodríguez $\mid$ Anal. Scient. Natur. Vol. 9. pag. 70 | culta in hoc regio horto anno 1801. Floruit Septembri") and the curatorial label [printed and typewritten (name) text: "Ex antiquo herbario generali | Herbarium Horti Botanici Matritensis | Chenopodium graveolens Lag. \& Rodr."]. It is listed in JSTOR Global Plants as "Type of Chenopodium graveolens Lag. et Rodr. ... (stored under name)". This specimen, which morphologically matches the original description by Lagasca and Rodríguez (1802: 70 ), is formally designated here as the lectotype of Chenopodium graveolens Lag. \& Rodr. (following the recommendations of McNeill, 2014).

Another presumably original specimen is available from the Herbario Universidad de Sevilla (SEV), SEV-H4090 (https://plants.jstor.org/stable/10.5555/al.ap. specimen.sev-h4090); it has a JSTOR Global Plants note "m. Rodríguez. Posible duplicado del pliego $\mathrm{n}^{\circ}$ HHUS 4089" and is listed as "Type of Chenopodium graveolens Lag. et Rodr. ... (stored under name)". The original status of that specimen is doubtful because no date of collection is available from the two labels on the sheet. However, the two plant fragments (branches) on that sheet clearly belong to the same species as Chenopodium graveolens sensu Willdenow (see comments on specimens from the Willdenow Herbarium below).

The specimen K000898413 (https://plants.jstor.org/ stable/10.5555/al.ap.specimen.k000898413) contains small plant fragments in an envelope; the sheet has also a typewritten excerpt from the protologue of Chenopodium graveolens Lag. \& Rodr. and the explanatory curatorial label "HERB. HORT. BOT. REG. KEW. | Chenopodium Botrys L. (C. graveolens | Lag. et Rodr.) | Specimen in Herb. Lagasca at Madrid, presumably | cultivated in the Botanic Garden there, Oct. 1822. | Specimen received on loan from the Jardin Botanico, Madrid, | 1949". It also has identification labels by Aellen ("Chenop. Botrys L.! | Det. Aellen 1961") and Uotila ("REVISIÓN PARA "FLORA IBERICA" | Chenopodium botrys L. | Det.-rev. Pertti Uotila XII 1984"), both indicating that the specimen belongs to C. botrys L. (now Dysphania botrys (L.) Mosyakin \& Clemants). Judging from the curatorial label and the date on it, that specimen does not belong to original material of $C$. graveolens Lag. \& Rodr. but in fact represents some plant cultivated under that name long after the actual date of publication of the name and description of $C$. graveolens Lag. \& Rodr. It should be noted that the name $C$. graveolens is not mentioned in the treatment of Chenopodium sensu lato in Flora Iberica (Uotila, 1990).
There are two specimens of Chenopodium graveolens in the Willdenow Herbarium at B. The specimen B-W05350-010 (https://plants.jstor.org/stable/10.5555/ al.ap.specimen.b\%20-w\%2005350\%20-01\%200) has Willdenow's inscription (top-right corner of the sheet) "Ch. graveolens. 1" and the annotation/identification label by Aellen: "Chenopodium graveolens Willd. | (Chenopodium incisum Poir. var. mexicanum Aellen).| det. P. Aellen | 10.03.1930". Another specimen, B-W05350-020 (https://plants.jstor.org/stable/10.5555/ al.ap.specimen.b $\% 20-\mathrm{w} \% 2005350 \% 20-02 \% 200)$, bears Willdenow's annotation (top-right corner of the sheet) "Ch. graveolens. 2".

Both these specimens from the Willdenow Herbarium belong to the same species as the specimen MA214007 (see above).

The specimen P00606423 (image and data available from $\quad$ https://plants.jstor.org/stable/10.5555/al.ap. specimen.p00606423) with the label "Chenopodium incisum | [illegible] | herb. Poiret. h. par. [hortus parisiensis]" seems to be the only original specimen of Chenopodium incisum Poir. directly associated with Poiret, and thus it is listed in JSTOR Global Plants as the "Holotype of Chenopodium incisum Poir.". It is conspecific with herbarium specimens of $C$. graveolens of Lagasca and Rodríguez and C. graveolens of Willdenow.

In my opinion, Art. 41.8(a) of the $I C N$ (Turland et al., 2018) is directly applicable here. According to that article, "On or after 1 January 1953, in any of the following cases, a full and direct reference to a work other than that in which the basionym or replaced synonym was validly published is treated as an error to be corrected, not affecting the valid publication of a new combination, name at new rank, or replacement name: $(a)$ when the actual basionym or replaced synonym was validly published earlier than the name or later isonym cited as such, but in the cited publication, in which all conditions for valid publication of the name as cited are fulfilled, there is no reference, in association with that name, to the place of valid publication of the actual basionym or replaced synonym $<\ldots>$.

We may assume that the plant species cultivated in Berlin under the name Chenopodium graveolens was received under that name either directly from Madrid or through some other botanical garden, and thus Willdenow used the name actually provided by Lagasca and Rodríguez but for some reason did not mention that reference. Thus, Mosyakin and Clemants (2002: 383) provided the full and direct reference to the description of C. graveolens in the book by Willdenow (1809), a work 
other than that in which the actual basionym was validly published (which was in fact the article by Lagasca and Rodríguez of 1802), but that should be treated as an error to be corrected because the actual basionym (in our case, C. graveolens Lag. \& Rodr.) was validly published earlier than the name or later isonym cited as such (C. graveolens attributed to Willdenow) but in the cited publication (Willdenow, 1809) all conditions for valid publication of the name as cited were fulfilled, and there was no reference to the place of valid publication of the actual basionym (Lagasca, Rodríguez, 1802). Consequently, a new combination in Dysphania based on Chenopodium incisum (provisionally cited in POWO as "Dysphania incisa (Poir.) ined.") is not needed. It should be also noted that Zhang and Zhu (2016; see also Zhu, Sanderson, 2017), when making a new nomenclatural combination Neobotrydium graveolens (Lag. \& Rodr.) M.L.Zhang \& G.L.Chu, cited the name by Lagasca and Rodríguez as the basionym.

The corrected nomenclatural citation of Dysphania graveolens is provided below:

Dysphania graveolens (Lag. \& Rodr.) Mosyakin \& Clemants, Ukrayins'k. Bot. Zhurn. [Ukr. Bot. J.] 59(4): 383 (2002) (cited with the authorship "(Willd.) Mosyakin \& Clemants"). $\equiv$ Chenopodium graveolens Lag. \& Rodr., Anales Ci. Nat. 5: 70 (1802). $\equiv$ Teloxys graveolens (Lag. \& Rodr.) W.A.Weber, Phytologia 58: 478 (1985), with the authorship "(Willd.) W.A.Weber" (see Weber, 1985: 478). $\equiv$ Neobotrydium graveolens (Lag. \& Rodr.) M.L.Zhang \& G.L.Chu, Pl. Diversity 38: 327 (2016) (see also Zhu, Sanderson, 2017: 73).

= Chenopodium graveolens Willd., Enum. Pl. Berol. 1: 290 (1809) (isonym?).

= Chenopodium incisum Poir., Encycl., Suppl. 1: 392 (1810).

\section{Acknowledgments}

I am grateful to colleagues who provided their assistance and expertise during the preparation of the present nomenclatural note, or provided PDF copies of some publications, especially to Rafaël H.A. Govaerts (Royal Botanical Gardens, Kew, U.K.), Pertti Uotila (Finnish Museum of Natural History, Botany Unit, University of Helsinki, Helsinki, Finland), and Filip Verloove (Meise Botanic Garden, Meise, Belgium). Ganna V. Boiko and Vera P. Hayova (M.G. Kholodny Institute of Botany, National Academy of Sciences of Ukraine,
Kyiv, Ukraine) guided the present submission through the editorial process and made several improvements in the text, and their assistance is gratefully acknowledged. Useful comments of two anonymous reviewers were gratefully accepted in the final version and are greatly appreciated.

\section{References}

Aellen P. 1930a. Die systematische Stellung und Gliederung der R. Brownischen Gattung Dysphania. Botanische Jahrbücher für Systematik, Pflanzengeschichte und Pflanzengeographie, 63: 482-490.

Aellen P. 1930b. Eine neue Sektion der Gattung Chenopodium (Sect. Tetrasepala). Botanische Jahrbücher für Systematik, Pflanzengeschichte und Pflanzengeographie, 63: 490-492.

Britton N.L., Coulter J.M., Rusby H.H., Kellerman W.A., Coville F.V., Underwood L.M., Ward L.F. 1894. List of Pteridophyta and Spermatophyta growing without cultivation in Northeastern North America. Memoirs of the Torrey Botanical Club, 5: 5-377.

Brown R. 1810. Prodromus florae Novae Hollandiae et Insulae Van-Diemen. Londini [London]: Typis Richardi Taylor \&socii, viii+ pp. 145-590. https://doi.org/10.5962/ $\underline{\text { bhl.title.52309 }}$

Cabrera J.F., Jacobs S.W.L., Kadereit G. 2009. Phylogeny of the Australian Camphorosmeae (Chenopodiaceae) and the taxonomic significance of the fruiting perianth. International Journal of Plant Sciences, 170(4): 505-521. https://doi.org/10.1086/597267

Cabrera J., Jacobs S.W.L., Kadereit G. 2011. Biogeography of Camphorosmeae (Chenopodiaceae): tracking the Tertiary history of Australian aridification. Telopea, 13(1-2): 313326. https://doi.org/10.7751/telopea20116023

Clemants S.E., Mosyakin S.L. 2003. Dysphania. In: Flora of North America Editorial Committee (eds.). Flora of North America North of Mexico, vol. 4. New York; Oxford: Oxford University Press, pp. 275-300.

Delile [Raffeneau-Delile] A. 1844. Index Seminum Horti Regii Botanici Monspeliensis, anni 1844. Monspelii [Montpellier], 4 pp.

Dillon S.J., Markey A.S. 2017. Dysphania congestiflora (Chenopodiaceae), a new species from Western Australia. Nuytsia, 27: 133-138. Available at: https://florabase.dpaw. wa.gov.au/nuytsia/article/793

Fuentes-Bazan S., Mansion G., Borsch T. 2012a. Towards a species level tree of the globally diverse genus Chenopodium (Chenopodiaceae). Molecular Phylogenetics and Evolution, 62: 359-374. https://doi. org/10.1016/j.ympev.2011.10.006

Fuentes-Bazan S., Uotila P., Borsch T. 2012b. A novel phylogeny-based generic classification for Chenopodium sensu lato, and a tribal rearrangement of Chenopodioideae (Chenopodiaceae). Willdenowia, 42(1): 5-24. https://doi. org/10.3372/wi.42.42101 
Hernández-Ledesma P., Berendsohn W.G., Borsch T., von Mering S., Akhani H., Arias S., Castañeda-Noa I., Eggli U., Eriksson R., Flores-Olvera H., FuentesBazán S., Kadereit G., Klak C., Korotkova N., Nyffeler R., Ocampo G., Ochoterena H., Oxelman B., Rabeler R.K., Sanchez A., Schlumpberger B.O., Uotila P. 2015. A taxonomic backbone for the global synthesis of species diversity in the angiosperm order Caryophyllales. Willdenowia, 45(3): 281-383. https://doi.org/10.3372/ wi.45.45301

IPNI. 2021-onward. International Plant Names Index. The Royal Botanic Gardens, Kew, Harvard University Herbaria \& Libraries and Australian National Botanic Gardens. Available at: https://www.ipni.org/ (Accessed 9 June 2021 and 5 July 2021).

Kadereit G., Freitag H. 2011. Molecular phylogeny of Camphorosmeae (Camphorosmoideae, Chenopodiaceae): Implications for biogeography, evolution of $\mathrm{C}_{4}$ photosynthesis and taxonomy. Taxon, 60(1): 51-78. https://doi.org/10.1002/tax.601006

Kühn U. (with additions by Bittrich V., Carolin R., Freitag H., Hedge I.C., Uotila P., Wilson P.G.) 1993. Chenopodiaceae. In: Kubitzki K., Rohwer J.G., Bittrich V. (eds.). The families and genera of vascular plants, vol. 2. Berlin; Heidelberg; New York: Springer; pp. 253-281.

Lagasca M., Rodriguez J. 1802. Descripciones de algunas plantas nuevas que han florecido en el Real establecimiento botanico en el año 1801. Anales de Ciencias Naturales (Madrid), 5: 65-76. Available at: https://www. biodiversitylibrary.org/bibliography/14767

McNeill J. 2014. Holotype specimens and type citations: general issues. Taxon, 63(5): 1112-1113. https://doi. org/10.12705/635.7

Moquin-Tandon A. 1834. Descriptions de plusieurs nouveaux genres de Chénopodées (Nova Chenopodearum genera). Annales des Sciences Naturelles (Paris), Sér. 2, 1: 203211, 289-294 + pl. 9, 10.

Moquin-Tandon A. 1840. Chenopodearum monographica enumeratio. Parisiis [Paris]: P.-J. Loss, xi + 182 pp. https:// doi.org/10.5962/bhl.title.15484

Moquin-Tandon A. 1849. Ordo Salsolaceae. In: Candolle A.P. (ed.), Prodromus systematis naturalis regni vegetabilis, vol. 13(2). Parisiis [Paris]: SumptibusVictoris Masson, pp. 41-219. https://doi.org/10.5962/bhl.title.286

Morales-Briones D.F., Kadereit G., Tefarikis D.T., Moore M.J., Smith S.A., Brockington S.F., Timoneda A., Yim W.C., Cushman J.C., Yang Y. 2021 (online before print: 2020). Disentangling sources of gene tree discordance in phylogenomic datasets: Testing ancient hybridizations in Amaranthaceae s.1. Systematic Biology, 70(2): 219-235. https://doi.org/10.1093/sysbio/syaa066

Mosyakin S.L. 2003. Cycloloma. In: Flora of North America Editorial Committee (eds.). Flora of North America North of Mexico, vol. 4. New York; Oxford: Oxford University Press, pp. 264-265.

Mosyakin S.L., Clemants S.E. 2002. New nomenclatural combinations in Dysphania R.Br. (Chenopodiaceae): Taxa occurring in North America. Ukrainian Botanical Journal,
59(4): 380-385. Available at: https://www.researchgate. net/publication/272417640

Mosyakin S.L., Clemants S.E. 2008. Further transfers of glandular-pubescent species from Chenopodium subgen. Ambrosia to Dysphania (Chenopodiaceae). Journal of the Botanical Research Institute of Texas, 2(1): 425-431. Available at: https://biostor.org/reference/157645 and https://www.biodiversitylibrary.org/part/161523

Mosyakin S.L., Iamonico D. 2017. Nomenclatural changes in Chenopodium (incl. Rhagodia) (Chenopodiaceae), with considerations on relationships of some Australian taxa and their possible Eurasian relatives. Nuytsia, 28: 255-271. Available at: https://florabase.dpaw.wa.gov.au/ science/nuytsia/843.pdf

POWO. 2021-onward. Plants of the World Online. Facilitated by the Royal Botanic Gardens, Kew. Available at: http:// www.plantsoftheworldonline.org/ (Accessed 9 June 2021 and 5 July 2021).

Reichenbach H.G.L. 1841. Das Herbarienbuch: Erklärung des natürlichen Pflanzensystems, systematische Aufzählung, Synonymik und Register der bis jetzt bekannten Pflanzengattungen... (Der deutsche Botaniker, Bd. 1). Dresden; Leipzig: In der Arnoldischen Buchhandlung, xcv + 240 pp. https://doi.org/10.5962/bhl.title.7694

Scott A.J. 1978a. Rhagodiinae: a new subtribe in the Chenopodiaceae. Feddes Repertorium 89(1): 1-11. https:// doi.org/10.1002/fedr.19780890102

Scott A.J. 1978b. A review of the classification of Chenopodium L. and related genera (Chenopodiaceae). Botanische Jahrbücher für Systematik, Pflanzengeschichte und Pflanzengeographie, 100(2): 205-220.

Scott A.J. 1978c. A revision of the Camphorosmioideae (Chenopodiaceae). Feddes Repertorium 89(2-3): 101119. https://doi.org/10.1002/fedr.19780890202

Simón L.E. 1996. Notas sobre Chenopodium L. subgen. Ambrosia A.J.Scott (Chenopodiaceae). 1. Taxonomía. 2. Fitogeografía: Áreas disyuntas. Anales del Jardin Botánico de Madrid, 54: 137-148.

Simón L.E. 1997. Variations des charactères foliares chez Chenopodium subg. Ambrosia sect. Adenois (Chenopodiaceae) en Amérique du Sud: Valeur taxonomique \& évolutive. Adansonia, sér. 3, 19(2): 293-320.

Sprengel K.[P.J.]. 1801. Erster Nachtrag zu der Beschreibung des botanischen Gartens der Universität zu Halle. Halle: Karl August Kümmel, viii + [9-] 44 pp.

Standley P.C. 1916. Chenopodiaceae. In: North American Flora, vol. 21(1). New York: The New York Botanical Garden, 93 pp. Available at: https:/www. biodiversitylibrary.org/item/15434

Turland N.J., Wiersema J.H., Barrie F.R., Greuter W., Hawksworth D.L., Herendeen P.S., Knapp S., Kusber W.-H., Li D.-Z., Marhold K., May T.W., McNeill J., Monro A.M., Prado J., Price M.J., Smith G.F. 2018. International Code of Nomenclature for algae, fungi, and plants (Shenzhen Code) adopted by the Nineteenth International Botanical Congress, Shenzhen, China, July 2017 [Regnum Vegetabile, vol. 159]. Glashütten: Koeltz 
Botanical Books, xxxviii + 254 pp. https://doi.org/10.1186/ s43008-019-0019-1

Uotila P. 1990. Chenopodium. In: Castroviejo S. (ed.). Flora Iberica, vol 2. Madrid: Real Jardín Botánico - CSIC, pp. 484-500.

Uotila P., Sukhorukov A.P., Bobon N., McDonald J., Krinitsina A.A., Kadereit G. 2021. Phylogeny, biogeography and systematics of Dysphanieae (Amaranthaceae). Taxon, 70(3): 526-551. https://doi.org/10.1002/tax.12458

Weber W.A. 1985. The genus Teloxys (Chenopodiaceae). Phytologia, 58(7): 477-478. Available at: https://www. biodiversitylibrary.org/part/176202

Willdenow C.L. 1809. Enumeratio Plantarum Horti Regii Botanici Berolinensis: continens descriptiones omnium vegetabilium in horto dicto cultorum. Berolini [Berlin]: In Taberna libraria Scholae Realis, vi + 1099 pp.
Wilson P.G. 1983. A taxonomic revision of the tribe Chenopodieae (Chenopodiaceae) in Australia. Nuytsia, 4(2): 135-262. Available at: https://www. biodiversitylibrary.org/page/53204842

Wilson P.G. 1984. Chenopodiaceae. In: George A.S. (ed.). Flora of Australia, vol. 4. Canberra: Australian Government Publishing Service, pp. 81-317.

Zhang M.L., Zhu G.L. 2016. Resurrection of the genus Botrydium Spach (Chenopodiaceae), with a description of four new species from China, Peru and Burundi. Plant Diversity, 38(6): 322-329. https://doi.org/10.1016/j. pld.2016.10.005

Zhu G.L., Sanderson S.C. 2017. Genera and a new evolutionary system of World Chenopodiaceae. Beijing: Science Press, 361 pp.

Recommended for publication by F. Verloove

Мосякін С.Л. 2021. Номенклатурні та таксономічні коментарі щодо деяких представників роду Dysphania (Chenopodiaceae s. str. / Amaranthaceae s. 1.). Украӥнський ботанічний журнал, 78(4): 266-273 [In English].

Інститут ботаніки ім. М.Г. Холодного НАН України, вул. Терещенківська 2, Київ 01601, Україна: С.Л. Мосякін

Реферат. Представлені коментарі щодо системи роду Dysphania у його уточненому обсязі, зміненому відповідно до результатів недавніх детальних молекулярно-філогенетичних досліджень (Uotila et al., 2021). Запропоновані зміни та доповнення до схеми 3 п'яти секцій, представленої Uotila et al. (2021). Зокрема, морфологічно чітко окреслена філогенетична лінія, що наразі містить єдиний вид Dysphania atriplicifolia (раніше загальновизнаний як єдиний вид роду Cycloloma, C. atriplicifolium), визнана як окрема секція - Dysphania sect. Cycloloma (Moq.) Mosyakin, comb. et stat. nov. Подана детальна синоніміка секції та їі єдиного виду. Філогенетичні лінії, виявлені в австралійській кладі Dysphania sect. Dysphania, досить добре окреслені морфологічно; раніше вони здебільшого визнавалися як секції Chenopodium (sensu lato) або Dysphania. Ці групи визнані тут як підсекції в межах Dysphania sect. Dysphania: (1) subsect. Orthospora (R.Br.) Mosyakin, comb. et stat. nov.; (2) subsect. Dysphania; та (3) subsect. Tetrasepalae (Aellen) Mosyakin, comb. et stat. nov. Обговорена проблема номенклатури Dysphania graveolens (三 Chenopodium graveolens). Підтверджено, що назва Chenopodium graveolens була вперше валідно опублікована не Вільденовом (Willdenow) у 1809 р., а Лагаскою (Lagasca) та Родрігесом (Rodríguez) у 1802 р. Оригінальні зразки, асоційовані з цією назвою в обох публікаціях, з таксономічної точки зору належать до виду, який зараз відомий як Dysphania graveolens (= Chenopodium incisum Poir.). На мою думку, тут слід застосувати Ст. 41.8(a) Міжнародного кодексу номенклатури водоростей, грибів та рослин (Шеньчженьський Кодекс). Відповідно, назва D. graveolens має цитуватися з уточненим авторством "(Lag. \& Rodr.) Mosyakin \& Clemants", а потенційна нова комбінація у роді Dysphania на основі базіоніму Chenopodium incisum (провізорно наведена у базі даних POWO як "Dysphania incisa (Poir.) ined.") не потрібна.

Ключові слова: Chenopodium, Cycloloma, Dysphania, номенклатура, систематика 
https://doi.org/10.15407/ukrbotj78.04.274

RESEARCH ARTICLE

\title{
Перша знахідка Phyllactinia moricola (Erysiphales, Ascomycota) на Morus alba в Свропі
}

\author{
Василь П. ГЕЛЮТА ${ }^{*}$ (D), Вікторія Г. КОРИТНЯНСЬКА² \\ ${ }^{1}$ Інститут ботаніки ім. М.Г. Холодного НАН України, вул. Терещенківська 2, Київ 01601, Україна \\ ${ }^{2}$ Національний науково-дослідний реставраційний центр України, Одеська філія, пр. Вознесенський 7, Одеса 65058, \\ Україна
}

\begin{abstract}
Information on the record of Phyllactinia moricola, a new in Ukraine alien powdery mildew fungus, is reported. The teleomorph of the fungus was collected in October-December 2020 on Morus alba in Odesa. The description and illustrations of the studied material are provided. The disease caused by this species can significantly reduce the ornamental properties of mulberry, a popular plant that is often used in greenery in the settlements of Ukraine. It is noted that the fungus can spread to Southern Europe, where it may cause significant damage to horticulture and silk production.
\end{abstract}

Keywords: adventive species, invasion, mulberry, powdery mildew, Ukraine

Article history. Submitted 28 July 2021. Revised 28 August 2021. Published 30 August 2021

Citation. Heluta V.P., Korytnianska V.G. 2021. First record of Phyllactinia moricola (Erysiphales, Ascomycota) on Morus alba in Europe. Ukrainian Botanical Journal, 78(4): 274-281 [In Ukrainian]. https://doi.org/10.15407/ukrbotj78.04.274

Affiliation. M.G. Kholodny Institute of Botany, National Academy of Sciences of Ukraine, 2 Tereshchenkivska Str., Kyiv 01601, Ukraine: V.P. Heluta. National Research Restoration Centre of Ukraine, Odesa Branch, 7 Voznesensky Ave., Odesa 65058, Ukraine: V.G. Korytnianska.

*Corresponding author (e-mail: vheluta@botany.kiev.ua)

\section{Вступ}

Список борошнисторосяних грибів Європи (Erysiphales, Ascomycota) постійно поповнюється через занесення сюди видів, природні ареали яких пов'язані насамперед з Північною Америкою та Східною Азією. Наприклад, за останні десятиріччя 3 Америки до Європи потрапили Erysiphe elevata (Burrill) U.Braun \& S.Takam. (Ale-Agha et al., 2004; Cook et al., 2004, 2006; Millevoj, 2004; Vajna et al., 2004; Kiss, 2005; Pastirčáková et al., 2006; Heluta et al., 2009a), E. flexuosa (Peck) U.Braun \& S.Takam. (Ale-Agha et al., 2000; Bolay, 2000; Zimmermannová-Pastirčáková et al., 2000; Piątek, 2002; Heluta, Voytyuk, 2004; Grigaliūnaitė et al., 2005), Golovinomyces greeneanus (U.Braun) Heluta (Heluta, Korytnianska, 2011), Podosphaera amelanchieris Maurizio (Braun, 2012; Kruse, 2014;
Bresinsky, 2016; Heluta, Hirylovich, 2016; Kruse et al., 2020) та ін., зі Східної Азії - E. corylacearum (Abasova et al., 2018; Beenken et al., 2019; Heluta et al., 2019; Heluta, Fokshei, 2020), E. deutziae (Bunkina) U.Braun \& S.Takam. (Bolay et al., 2005; Mułenko et al., 2010; Bresinsky, 2016), E. magnifica (U.Braun) U.Braun \& S.Takam. (Braun et al., 2009; Palahecha, Chumak, 2011; Bresinsky, 2016), E. salmonii (Syd. \& P.Syd.) U.Braun \& S.Takam. (Heluta et al., 2017; Beenken, Brodtbeck, 2020), E. syringae-japonicae (U.Braun) U.Braun \& S.Takam. (Braun, 1998; Bolay, 2005; Seko et al., 2008, 2011), Neoerysiphe geranii (Y.Nomura) U.Braun (Heluta, 2001; Heluta et al., 2010; Bresinsky, 2016) тощо. Зрідка в Свропу мігрують види і з Центральної Азії. До таких можемо віднести E. kenjiana (Homma) U.Braun \& S.Takam. (Heluta et al., 2009b; Korytnianska et al., 2012; Chinan, 2019) та Podosphaera parietariae (Schwarzman) U.Braun \& S.Takam. (Heluta et al., 2004).

(C) 2021 V.P. Heluta, V.G. Korytnianska. Published by the M.G. Kholodny Institute of Botany, NAS of Ukraine. This is an open access article under the terms of the Creative Commons Attribution License (http://creativecommons.org/licenses/by/4.0/), which permits use, distribution, and reproduction in any medium, provided the original work is properly cited 
У цій статті ми повідомляємо про знахідку в Європі (Україна) ще одного виду борошнисторосяних грибів, Phyllactinia moricola (Henn.) Homma, сучасний ареал якого приурочений до регіонів 3 теплим кліматом. Очевидно, в Україну він потрапив 3 Центральної Азії.

\section{Матеріали та методи}

У 2020 р. під час обстеження зелених насаджень м. Одеса одним з авторів статті (В.Г. Коритнянською) були зібрані листки шовковиці, уражені з нижнього боку борошнистою росою. Збудник хвороби розвивався як на листках гілок, що відросли на штамбі Morus alba f. pendula Dipp., так і порості M. alba L. (самосів). Дослідження гриба проводилося на гербаризованому матеріалі. Препарати для світлової мікроскопії готувалися стандартно, в дистильованій воді. Усі структури гриба фотографувалися i вимірювалися під мікроскопом "Primo Star" (Carl Zeiss, Німеччина) з використанням камери "Canon A 300" та програмного забезпечення "AxioVision 4.7". Отримані кількісні дані оброблялися статистично при $\mathrm{n} \geq 30$ для кожного параметра. Зібрані зразки зберігаються в Національному гербарії Інституту ботаніки ім. М.Г. Холодного НАН України (KWM71466 i KW-M71482) та у власному мікологічному гербарії В.Г. Коритнянської.

\section{Результати та обговорення}

В Україні більш чи менш широко відомі три види шовковиці - Morus alba L., M. nigra L. та M. rubra L. Всі вони $є$ інтродуцентами різного географічного походження. Два перші завезені з Азії, тоді як M. rubra є північноамериканським видом. 3 них, M. alba була інтродукована в Україну, очевидно, ще в XVI столітті і зараз $€$ тут звичайною рослиною, тоді як M. nigra зрідка вирощується в Криму, а M. rubra - лише в деяких ботанічних садах (Kokhno et al., 1986). Morus alba культивується в Україні переважно в південній іï частині - насамперед у степовій зоні, однак іï часто розводять і в Лісостепу. Вона вирощується в парках та садах, головним чином через декоративність та цінні фармакологічні властивості. Для лікарських цілей заготовляють листя, кору стовбурів та коренів, а також плоди. Останні використовуються і як харчовий продукт (Shovkovytsya..., 1992). Різноманітні сорти M. alba (біло-, рожево- та чорноплідні) належать до улюблених культур на присадибних ділянках, нерідко також вирощуються у полезахисних лісосмугах. У XVIII-XX ст. шовковицю інтенсивно культивували в Україні з метою вирощування гусені шовкопряда (Vitenko, 2008; Boroday, 2009; Lyubych, 2017; Rudnyk-Ivashchenko, Sukhomlyn, 2017). У наш час пропонується використовувати цю культуру в органічному тваринництві (Babayeva et al., 2016). Додамо, що з селекційними цілями в Україні також можуть вирощувати й деякі інші види шовковиці, наприклад, M. indica L. (= M. bombycis Koidz.) та M. multicaulis (Perr.) Perr. (M. alba s. 1.), або ж їх гібриди з M. alba (Lyutenko et al., 2015).

3 огляду на велике практичне значення шовковиці в житті людини нами та іншими мікологами проводиться постійний пошук на цій культурі борошнистої роси. За багато років була лише одна вказівка на те, що шовковиця в Україні вражувалася хворобою, спричиненою грибом Uncinula mori Miyake (сучасна прийнята назва - Erysiphe mori (Miyake) U.Braun \& S.Takam.). Гриб наводився для Лівобережного Злакового Степу (Morochkovskyi et al., 1969). Однак пізніше він більше ніколи не реєструвався в Україні, його зразок у Національному гербарії України (KW-M) відсутній, а в інших джерелах згадки про зазначений вид гриба не наводилися. Очевидно, це була помилкова вказівка для України цього азійського виду.

У світі, крім E. mori, шовковиця також інфікується грибами $з$ роду Phyllactinia Lév. Так, У. Браун та Р. Кук (Braun, Cook, 2012) для багатьох видів роду Morus L., а також й інших родів родини Moraceae Broussonetia L'Hér. ex Vent. тa Maclura Nutt. s. 1. (Cudrania Trécul) - наводять гриб P. moricola 3 дуже широким ареалом. Вид під різними назвами (також і як P. corylea (Pers.) P.Karst., P. guttata (Wallr.) Lév. та $P$. suffulta (Rebent.) Sacc.) відомий 3 Африки, Північної та Південної Америки, з багатьох країн Азії та Нової Зеландії. На території Європи раніше він, очевидно, не реєструвався. Однак при обстеженні зелених насаджень Одеси одним 3 авторів цього повідомлення виявлені рослини M. alba, листки яких були уражені саме грибом з роду Phyllactinia (рис. 1). За морфологічними ознаками гриб доволі добре вкладається в рамки опису P. moricola, наведеного Брауном та Куком (Braun, Cook, 2012), його кількісні характеристики були близькими до поданих іншими авторами (таблиця 1). Отже, на шовковиці ми знайшли гриб, до цих пір невідомий в Україні, можливо, і в Європі. Нижче наводимо опис дослідженого нами матеріалу. 

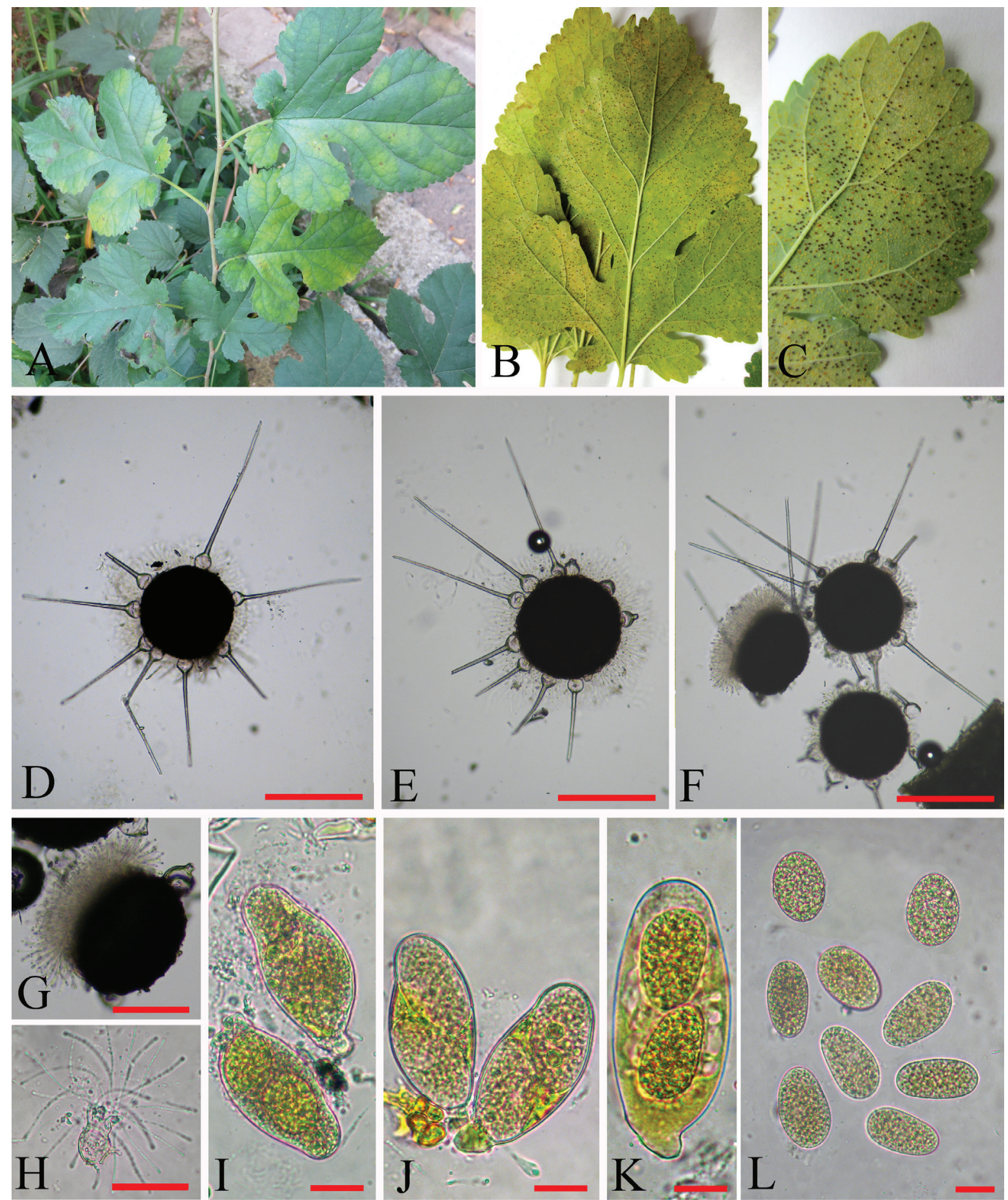

Рис. 1. Phyllactinia moricola на Morus alba. A-C: уражені грибом листки шовковиці (А: вигляд зверху, видно хлоротичні плями, B-C: вигляд знизу); D-F: плодові тіла; G: плодове тіло з клейкими клітинами у верхній частині; Н: клейка клітина з липкими желатинізованими додатками; I-K: сумки (J: трохи придавлені, К: розплющена покривним скельцем); $\mathrm{L}$ : сумкоспори (розмір штриха: D-F - 200 мкм, G - 100 мкм, H - 50 мкм, I-L - 20 мкм)

Fig. 1. Phyllactinia moricola on Morus alba. A-C: infected mulberry leaves (A: top view, chlorotic spots are visible; B-C: bottom view); D-F: chasmothecia; G: chasmothecium with the penicillate cells at the top; H: penicillate cell with gelatinized filaments; I-K: asci (J: slightly pressed, K: flattened by a cover glass); L: ascospores. Bars: D-F $-200 \mu \mathrm{m}, \mathrm{G}-100 \mu \mathrm{m}, \mathrm{H}-50 \mu \mathrm{m}, \mathrm{I}-\mathrm{L}-20 \mu \mathrm{m}$ 
Таблиця 1. Кількісні характеристики Phyllactinia moricola, наведені різними авторами (подано у мікрометрах) Table 1. Quantitative characters of Phyllactinia moricola after various authors (in $\mu \mathrm{m})$

\begin{tabular}{|l|c|c|c|c|}
\hline \multicolumn{1}{|c|}{ Автор } & Розмір конідій & Діаметр хазмотецію & Розмір сумок & Розмір спор \\
\hline Jaczewsky, 1927 & $70 \times 18$ & $135-195$ & $55-75 \times 25-30$ & $30 \times 18$ \\
\hline Vasyagina et al., 1961 & $70 \times 18$ & $177-209$ & $64-74 \times 32-38$ & $29-32 \times 20-23$ \\
\hline Gaponenko et al., 1983 & $52-73 \times 17-26$ & $128-205$ & $61-81 \times 26-35$ & $29-32 \times 20-22$ \\
\hline Chen et al., 1987 & $55-85 \times 20-30$ & $138-277$ & $50-94 \times 15-49$ & $20-45 \times 15-30$ \\
\hline Bunkina, 1991 & $65-95 \times 18-26$ & $155-185$ & $59-76 \times 26-36$ & $23-30 \times 17-20$ \\
\hline Shin, 2000 & $60-85 \times 20-26$ & $148-192$ & $68-80 \times 36-46$ & $26-40 \times 18-24$ \\
\hline Braun, Cook, 2012 & $45-95 \times 15-35$ & $140-280$ & $50-95 \times 15-50$ & $18-50 \times 15-30$ \\
\hline Наш матеріал & - & $178-243$ & $54-80 \times 22-41$ & $32-46 \times 18-27$ \\
\hline
\end{tabular}

Phyllactinia moricola (Henn.) Homma, Trans. Sapporo Nat. Hist. Soc. 11: 174. [1929] 1930 (рис. 1, A-L)

Syn.: Phyllactinia suffulta var. moricola Henn., Jahrb. Syst. 28(3): 271. 1900; Phyllactinia suffulta f. moricola Jacz. (Jaczewski 1927: 434); Phyllactinia moricola (Henn.) Sawada, Rep. Dept. Agric. Gov. Res. Inst. Formosa 49: 84. 1930; Phyllactinia corylea auct. p.p.; Phyllactinia guttata auct. p.p.; Phyllactinia suffulta auct. p.p.

Anamorph: Ovulariopsis moricola Delacr., Bull. Trimestriel Soc. Mycol. France 19: 345. 1903.

Міцелій гриба розвивається на нижньому боці листкової пластинки у вигляді чітких білих плям, які згодом зливаються та повністю вкривають всю їі поверхню. В місцях розвитку міцелію спостерігається хлороз. Анаморфа - Ovulariopsis moricola Delacr. Траплялися лише поодинокі конідії, розкидані по поверхні листкової пластинки. Хазмотеції численні, розсіяні, чорні, кулясті, діаметром 178-238 (-243) мкм. Клітини оболонки хазмотецію - неправильні багатокутники, 5-25 (-30) мкм. Придатки екваторіальні, 7-25, зазвичай 9-14, прямі, прості, тонкостінні, несептовані, безбарвні, з тупими або злегка загостреними кінчиками, довжиною 170 386 мкм. Сумки по (5-) 12-30 (-45), на короткій ніжці або без неї, тонкостінні, еліпсоїднояйцеподібні, булавоподібні, часто нерівнобокі, 54-80 $\times$ (22-) 27- 41 мкм, 2-спорові. Спори мінливі за розмірами і формою - переважно яйцеподібні (від короткояйцеподібних до доволі видовжених), нерідко еліпсоїдні, часто дещо зігнуті, безбарвні або блідооливково-зеленуваті, 32-46 × 18-27 мкм.

Ha Morus alba L. - м. Одеса, Приморський р-н, пр. Вознесенський, 07.10, 19.10.2020, В.Г. Коритнянська; там само, 17.11.2020, В.Г. Коритнянська, KW-M71466.

Ha Morus alba L. f. pendula - м. Одеса, Приморський p-н, пр. Вознесенський, 07.10, 19.10.2020, В.Г. Коритнянська; там само, В.Г. Коритнянська, 03.12.2020, KW-M71482.

Украйнський ботанічний журнал, 2021, 78(4)
На сьогодні P. moricola наводиться для багатьох регіонів світу, розташованих на різних континентах. Вона вказується для країн Азії (Азербайджан, Афганістан, Бангладеш, Бірма, Вірменія, В'єтнам, Грузія, Ізраїль, Індія, Індонезія, Ірак, Іран, Йорданія, Казахстан, Киргизстан, Китай, Кіпр, Корея, Ліван, Маврикій, Малайзія, М'янма, Пакистан, Росія (Сибір та Далекий Схід), Сінгапур, Узбекистан, Таїланд, Туреччина, Туркменістан, Філіппіни, ШріЛанка, Японія), Африки (Сгипет, Замбія, Зімбабве, Кенія, Мадагаскар, Малаві, Мозамбік, ПівденноАфриканська Республіка, Танзанія), Північної Америки (США) та Південної Америки (Бразилія), а також знайдена в Новій Зеландії (Vasyagina et al., 1961; Akhundov, 1979; Gaponenko et al., 1983; Amano, 1986; Chen et al., 1987; Gorter, Eicker, 1987; Bunkina, 1991; Simonyan, 1994; Shin, 2000; Kurt, Soylu, 2001; Babu et al., 2002; Khodaparast et al., 2005; Pirnia et al., 2006, 2007; Takamatsu et al., 2008; Sharma et al., 2011; Braun, Cook, 2012; Meeboon et al., 2018; Farr, Rossman, 2021). Додамо, що в загальносвітовому списку борошнисторосяних грибів, складеному К. Амано (Amano, 1986), P. moricola на M. alba вказується для Німеччини, європейської частини колишнього СРСР та України. Однак підтвердження цієї інформації не знаходимо ні у відповідних європейських монографіях (Blumer, 1967; Braun, Cook, 2012), ні у виданнях колишнього СРСР (Gorlenko, 1983; Heluta, 1989; Grigaliūnaite, 1990; Hirylovich, Lemeza, 2015).

Зазначимо, що останнім часом було показано певну генетичну гетерогенність збудників борошнистої роси шовковичних. Так, китайські мікологи встановили, що у Китаї $M$. alba уражується грибом, який не належить до P. moricola, і наводять його як Phyllactinia sp. (Wang et al., 2014). В іншому дослідженні, окрім уже відомих $P$. moricola та P. broussonetiae-kaempferi Sawada, на шовковичних описано з Таїланду ще один вид - P. mori-macrourae Meeboon \& S.Takam., а для Ovulariopsis broussonetiaepapyriferae Sawada був підтверджений статус 277 
окремого виду та запропоновано нову комбінацію P. broussonetiae-papyriferae (Sawada) Meeboon \& S.Takam. (Meeboon et al., 2018). Отже, бачимо, що у світлі цієї інформації сучасне розповсюдження P. moricola потребує додаткового дослідження, оскільки в ряді південних країн цілком можливе поширення хоча й близьких, але все ж таки інших видів.

Спалахи борошнистої роси шовковиці в країнах, де традиційно займаються шовківництвом, загрожують розвитку галузі, оскільки уражене цим грибом листя стає непридатним для вирощування гусениць метеликів тутового шовкопряда через значне зменшення вмісту в листковій пластинці поживних речовин, хлороз та деформацію (скручування i зменшення розміру листа) (Monir, Mandal, 2016). Оскільки в умовах південної України спостерігається доволі сильне ураження листків $M$. alba, що супроводжується плямами хлорозу різної ступені інтенсивності, то хвороба, спиричинена грибом P. moricola, потрапивши до країн Південної Свропи, буде завдавати там значних збитків у садівництві та при виробництві шовку.

\section{Список посилань}

Abasova L.V., Aghayeva D.N., Takamatsu S. 2018. Notes on powdery mildews of the genus Erysiphe from Azerbaijan. Current Research in Environmental \& Applied Mycology, 8(1): 30-53. https://doi.org/10.5943/cream/8/1/3

Akhundov T.M. 1979. Mikoflora Nakhichevanskoy ASSR. Baku: Elm, 168 pр. [Ахундов T.M. 1979. Микофлора Нахичеванской АССР. Баку: Элм, 168 с.]

Ale-Agha N., Bolay A., Braun U., Feige B., Jage H., Kummer V., Lebeda A., Piątek A., Shin H.-D., ZimmermannováPastirčaková K. 2004. Erysiphe catalpae and Erysiphe elevata in Europe. Mycological Progress, 3(4): 291-296.

Ale-Agha N., Braun U., Feige B., Jage H. 2000. A new powdery mildew disease on Aesculus spp. introduced in Europe. Cryptogamie Mycologie, 21(2): 89-92. https:// doi.org/10.1016/S0181-1584(00)00117-2

Amano K. 1986. Host range and geographical distribution of the powdery mildew fungi. Tokyo: Japan Scientific Societies Press, 741 pp.

Babayeva H.I., Lytvyn V.M., Voytenko V.I., Khmelova T.S. 2016. Veterynarna medytsyna, 102: 241-243. [Бабаєва Г.I., Литвин В.М., Войтенко В.І., Хмельова Т.С. 2016. Спосіб застосування шовковиці на шляху переходу тваринництва до виробництва органічної продукції. Ветеринарна медицина, 102: 241-243].

Babu A.M., Kumar J.S., Kumar V., Sarkar A., Datta R.K. 2002. Tropic failure of Phyllactinia corylea contributes to the mildew resistance of mulberry genotypes. Mycopathologia, 156: 207-213.

Beenken L., Brodtbeck T. 2020. First record of Erysiphe salmonii causing powdery mildew on Fraxinus ornus in Switzerland. New Disease Reports, 42: 22. http://dx.doi.or $\mathrm{g} / 10.5197 / \mathrm{j} .2044-0588.2020 .042 .022$

Beenken L., Brodtbeck T., De Marchi R. 2019. First record of Erysiphe corylacearum on Corylus avellana in Switzerland and in central Europe. New Disease Reports, 41: 11. https://doi.org/10.5197/j.2044-0588.2020.041.011

Blumer S. 1967. Echte Mehltaupilze (Erysiphaceae). Ein Bestimmungsbuch für die in Europa vorkommenden Arten. Jena: Gustav Fischer Verlag, 436 pp.

Bolay A. 2000. L'oïdium des marroniers envahit la Suisse. Revue Suisse de Viticulture Arboriculture Horticulture, 32(6): 311-313.

Bolay A. 2005. Les oidiums de Suisse (Erysiphaceae). Cryptogamica Helvetica, 20: 1-173.

Bolay A., Braun U., Delhey R., Kummer V., Piątek M., Wołczańska A. 2005. Erysiphe deutziae - a new epidemic spread in Europe. Cryptogamie, Mycologie, 26(4): 193-298.

Boroday I.S. 2009. Sumska starovyna, 26-27: 42-48. [Бородай I.C. 2009. 3 історії становлення та розвитку шовківництва в Україні. Сумська старовина, 26-27: 42-48].

Braun U. 1998. Neufunde Echter Mehltaupilze (Erysiphales) aus der B.R. Deutschland. Schlechtendalia, 1: 31-40.

Braun U. 2012. Fungi selecti exsiccati ex Herbario Universitatis Halensis nos. 141-190. Schlechtendalia, 24: 73-90.

Braun U., Ale-Agha N., Bolay A., Boyle H., BrielmaierLiebetanz U., Emgenbroich D., Kruse J., Kummer V. 2009. New records of powdery mildew fungi (Erysiphaceae). Schlechtendalia, 19: 39-46.

Braun U., Cook R.T.A. 2012. Taxonomic manual of the Erysiphales (powdery mildews). Utrecht: CBS-KNAW Fungal Biodiversity Centre, 707 pp.

Bresinsky A. 2016. Echte Mehltaupilze (Erysiphales) in Bayern - eine vorläufige Übersicht. Berichte der Bayerischen Botanischen Gesellschaft, 86: 163-212.

Bunkina I.A. 1991. In: Nizshie rasteniya, griby $i$ mokhoobraznye sovetskogo Dalnego Vostoka. Griby, vol. 2. Askomitsety. Erizifalnye, klavitsipitalnye, gelotsialnye. Ed. Z.M. Azbukina. Leningrad: Nauka, pp. 11-142. [Бункина И.А. 1991. Порядок Erysiphales. В кн.: Низшие растения, грибы и мохообразные советского Дальнего Востока. Грибы, т. 2. Аскомицетыл. Эризифальные, клавиципитальные, гелоччиальные. Отв. ред. 3.М. Азбукина. Ленинград: Наука, с. 11-142].

Chen G., Han S., Lai Y., Yu Y., Zheng R. 1987. Flora Fungorum Sinicorum, vol. 1. Erysiphales. China: Science press, $552 \mathrm{pp}$.

Chinan V.-C. 2019. First report of Erysiphe kenjiana causing powdery mildew of elm in Romania. Forest Pathology, 49(6): e12548. https://doi.org/10.1111/efp.12548

Ukrainian Botanical Journal, 2021, 78(4) 
Cook R.T.A., Henricot B., Kiss L. 2004. First record of Erysiphe elevata on Catalpa bignonioides in the UK. Plant Pathology, 53: 807.

Cook R.T.A., Henricot B., Henrici A., Beales P. 2006. Morphological and phylogenetic comparisons amongst powdery mildews on Catalpa in the UK. Mycological Research, 110: 672-685.

Farr D.F., Rossman A.Y. 2021. Fungal Databases, U.S. National Fungus Collections, ARS, USDA. Available at: https://nt.ars-grin.gov/fungaldatabases (Accessed 24 January 2021).

Gaponenko N.I., Akhmedova F.G., Ramazanova S.S., Sagdullaeva M.Sh., Kirgizbaeva Kh.M. 1983. Flora gribov Uzbekistana, vol. 1. Muchnistorosyanye griby. Tashkent: FAN, 362 pp. [Гапоненко Н.И., Ахмедова Ф.Г., Рамазанова С.С., Сагдуллаева М.Ш., Киргизбаева Х.М. 1983. Флора грибов Узбекистана, т. 1. Мучнисторосяные грибы. Ташкент: ФАН, 362 с.].

Gorlenko M.V. 1983. Muchnistorosyanye griby Moskovskoy oblasti. Semeystvo Erysiphaceae. Moscow: Izd-vo MGU, 73 pp. [Горленко М.В. 1983. Мучнисторосяные грибы Московской области. Семейство Erysiphaceae. Москва: Изд-во МГУ, 73 с.].

Gorter G.J.M.A., Eicker A. 1987. Additional first records of perfect stages of some powdery mildew fungi in Southa Africa. South African Journal of Botany, 53(1): 93-97.

Grigaliūnaitė B. 1990. Muchnisto-rosyanye griby Litvy. Vilnyus: Mokslas, 88 pp. [Григалюнайте Б. 1990. Мучнисто-росяные грибы Литвы. Вильнюс: Мокслас, 88 c.].

Grigaliūnaitė B., Meškauskienė V., Matelis A., 2005. Erysiphe flexuosa on Aesculus hippocastanum in Lithuania. Botanica Lithuanica, 11(1): 63-65.

Heluta V.P. 1989. Flora gribov Ukrainy. Muchnistorosyanye griby. Kiev: Naukova Dumka, 256 pр. [Гелюта В.П. 1989. Флора грибов Украины. Мучнисторосяные грибы. Киев: Наукова думка, 256 с.].

Heluta V.P. 2001. Ukrainian Botanical Journal, 58(2): 239242. [Гелюта В.П. 2001. Neoerysiphe geranii (Y.Nomura) U.Braun - новий для України вид борошнисторосяного гриба. Український ботанічний журнал, 58(2): 239-242].

Heluta V.P., Dzyunenko O.O., Cook R.T.A., Isikov V.P. 2009. New records of Erysiphe species on Catalpa bignonioides in Ukraine. Ukrainian Botanical Journal, 66(3): 346-353.

Heluta V.P., Fokshei S.I. 2020. New records of an alien fungus Erysiphe corylacearum (Erysiphales, Ascomycota) in Ukraine. Plant \& Fungal Research, 3(1): 11-17. http:// dx.doi.org/10.29228/plantfungalres.64

Heluta V.P., Hirylovich I.S. 2016. First records of an invasive fungus Podosphaera amelanchieris (Erysiphales) in Belarus and Ukraine. Ukrainian Botanical Journal, 73(1): 78-83. https://doi.org/10.15407/ukrbotj73.01.078

Heluta V.P., Korytnianska V.H. 2011. Ukrainian Botanical Journal, 68(5): 773-779. [Гелюта В.П., Коритнянська В.Г. 2011. Golovinomyces greeneanus (U.Braun) Heluta (Erysiphales) - новий для України вид борошнисторосяних грибів. Украӥнський ботанічний журнал, 68(5): 773-779].

Heluta V.P., Makarenko N.V., Al-Maali G.A. 2019. First records of Erysiphe corylacearum (Erysiphales, Ascomycota) on Corylus avellana in Ukraine. Ukrainian Botanical Journal, 76(3): 252-259. https://doi. org/10.15407/ukrbotj76.03.252

Heluta V., Takamatsu S., Harada M., Voytyuk S. 2010. Molecular phylogeny and taxonomy of Eurasian Neoerysiphe species infecting Asteraceae and Geranium. Persoonia, 24: 81-92.

Heluta V.P., Takamatsu S., Siahaan S.A.S. 2017. Erysiphe salmonii (Erysiphales, Ascomycota), another East Asian powdery mildew fungus introduced to Ukraine. Ukrainian Botanical Journal, 74(3): 212-219. https://doi. org/10.15407/ukrbotj74.03.212

Heluta V.P, Takamatsu S., Voytyuk S.O., Shiroya Y. 2009. Erysiphe kenjiana (Erysiphales), a new invasive fungus in Europe. Mycological Progress, 8(4): 367-375.

Heluta V.P., Voytyuk S.O. 2004. Ukrainian Botanical Journal, 61(5): 17-25. [Гелюта В.П., Войтюк С.О. 2004. Uncinula flexuosa Peck. - новий для України вид інвазійного борошнисторосяного гриба (Erysiphales). Український ботанічний журнал, 61(5): 17-25].

Heluta V., Wasser S., Voytyuk S. 2004. Sphaerotheca parietariae (Erysiphales, Eumycota), a new powdery mildew fungus in Europe. Flora Mediterranea, 14: 285-289.

Hirylovich I.S., Lemeza N.A. 2015. Vestsi Natsyyanalnay akademii navuk Belarusi, 4: 77-82. [Гирилович И.С., Лемеза Н.А. 2015. Эризифальные грибы рода Phyllactinia Lév. в Беларуси. Весuі Нацьыянальнай акадэміі навук Беларусі, 4: 77-82].

Jaczewsky A.A. 1927. Karmannyi opredelitel gribov. Vypusk vtoroy. Muchnisto-rosyanye griby. Leningrad, $626 \mathrm{pp}$. [Ячевский А.А. 1927. Карманнылй определитель грибов. Выпуск второй. Мучнисто-росяные грибы. Ленинград, 626 с.].

Khodaparast S.A., Takamatsu S., Hedjaroude G.A. 2005. Phylogenetic analysis of Iranian powdery mildew fungi using nucleotide sequences of $28 \mathrm{~S}$ ribosomal DNA. Journal of Agricultural Science and Technology, 7: 49-58.

Kiss L. 2005. Powdery mildew as invasive plant pathogens: new epidemics caused by two North American species in Europe. Mycological Research, 109(3): 257-258.

Kokhno N.A., Kaplunenko N.F., Minchenko N.F., Doroshenko A.K., Horb V.K., Orlov M.I., Kurdyuk A.M., Parkhomenko L.I., Tsikalyak H.P., Mamushkina T.S., Hordienko N.M. 1986. Derevya i kustarniki, kultiviruemye $v$ Ukrainskoy SSR. Pokrytosemennye. Kyiv: Naukova Dumka, 720 pp. [Кохно Н.А., Каплуненко Н.Ф., Минченко Н.Ф., Дорошенко А.К., Горб В.К., Орлов М.И., Курдюк А.М., Пархоменко Л.И., Цикаляк Г.П., Мамушкина Т.С., Гордиенко Н.М. 1986. Деревья и кустарники, культивируемье в Украинской ССР. Покрытосеменные. Київ: Наукова думка, 720 с.].

Korytnianska V.H., Tovstukha N.I., Popova O.M. 2012. Chornomorskyi botanichnyi zhurnal, 8(4): 446-458. 
[Коритнянська В.Г., Товстуха Н.І., Попова О.М. 2012. Облігатнопаразитні фітотрофні гриби деяких парків та скверів міста Одеси. Чорноморський ботанічний журнал, 8(4): 446-458].

Kruse J. 2014. Diversität der pflanzenpathogenen Kleinpilze im Ökologisch-Botanischen Garten der Universität Bayreuth. Zeitschrift für Mykologie, 80(1): 169-226.

Kruse J., Thiel H., Rätzel S., Schmidt A., Schreier S., Simmat U., Kummer V. 2020. Bemerkenswerte Funde phytoparasitischer Kleinpilze (13). Zeitschrift für Mykologie, 86(1): 77-119.

Kurt S., Soylu S. 2001. First report of powdery mildew on mulberry caused by Phyllactinia guttata in the Eastern Mediterranean Region of Turkey. New Disease Reports, 3,7. Available at: https://www.ndrs.org.uk/article. php?id=003007

Lyubych O.A. 2017. Naukovi pratsi istorychnoho fakultetu Zaporizkoho natsionalnoho universytetu, 48: 47-50. [Любич О.А. 2017. Промислове виробництво та обробка шовку в козацьких та поміщицьких господарствах Чернігівської губернії в XIX ст. Наукові праці історичного факультету Запорізького національного університету, 48: 47-50].

Lyutenko V.S., Babayeva H.I., Lytvyn V.M., Voytenko V.I., Khmelova T.S. 2015. Visnyk ahrarnoi nauky, 93(2): 37-40. [Лютенко В.С., Бабаєва Г.І., Литвин В.М., Войтенко В.I., Хмельова Т.С. 2015. Автономний апоміксис у рослин роду Morus. Вісник аграрної науки, 93(2): 37-40].

Meeboon J., Kokaew J., Takamatsu S. 2018. Notes on powdery mildews (Erysiphales) in Thailand VI. Phyllactinia and Leveillula. Mycological Progress, 17: 701-718.

Millevoj L. 2004. The occurence of some pests and diseases on horse chestnut, plane tree and Indian bean tree in urban areas of Slovenia. Acta agriculturae slovenica, 83(2): 297-300.

Monir S., Mandal N.C. 2016. A review on powdery mildew of mulberry and its management. International Journal of Bioresource, Environment and Agricultural Sciences (IJBEAS), 2(2): 281-286.

Morochkovskyi S.F., Zerova M.Ya., Lavitska Z.H., Smitska M.F. 1969. Vyznachnyk hrybiv Ukrainy, vol. 2. Askomitsety. Kyiv: Naukova Dumka, 517 pp. [Морочковський С.Ф., Зерова М.Я., Лавітська З.Г., Сміцька М.Ф. 1969. Визначник грибів України, т. 2. Аскоміцети. Київ: Наукова думка, 517 с.].

Mułenko W., Piątek M., Wołczańska A., Kozłowska M., Ruszkiewicz-Michalska M. 2010. Plant parasitic fungi introduced to Poland in modern times. Alien and invasive species. Biological Invasions in Poland, 1: 49-71.

Palahecha R.M., Chumak P.Ya. 2011. In: Materialy XIII z'yizdu Ukrainskoho botananichnoho tovarystva. Lviv: Prostir M, p. 313. [Палагеча Р.М., Чумак П.Я. 2011. Еколого-морфологічна структура субпопуляції Microsphaera magnifica U.Braun (Erysiphales) та інвазійна спроможність цього гриба. В зб.: Матеріали ХІІІ з'їзуу Украӥнського ботанічного товариства. Львів: Простір М, с. 313].
Pastirčáková K., Pastirčák M., Juhásová G. 2006. The Catalpa powdery mildew Erysiphe elevata in Slovakia. Cryptogamie, Mycologie, 27(1): 31-34.

Piątek M. 2002. Erysiphe flexuosa, a new for Poland powdery mildew causing disease of Aesculus hippocastanum. Phytopathologia Polonica, 24: 67-71.

Pirnia M., Khodaparast S.A., Abbasi M. 2006. Morphology of penicillate cells in the genus Phyllactinia (Erysiphaceae) based on Iranian specimens. Rostaniha, 7(2): 125-145.

Pirnia M., Khodaparast S.A., Abbasi M., Tavanaei Gh.H. 2007. Study on the genus Phyllactinia (Erysiphaceae) in Iran. Iranian Journal of Plant Pathology, 43(4(172)): 445-464.

Rudnyk-Ivashchenko O.I., Sukhomlyn L.V. 2017. Sadivnytstvo, 72: 45-49. [Рудник-Іващенко O.I., Сухомлин Л.В. 2017. Шовковиця (Morus L.): iii реалії та майбутне в Україні. Садівницттво, 72: 45-49].

Seko Y., Bolay A., Kiss L., Heluta V., Grigaliūnaitė B., Takamatsu S. 2008. Molecular evidence in support of recent migration of a powdery mildew fungus on Syringa spp. into Europe from East Asia. Plant Pathology, 57(2): 243250. https://doi.org/10.1111/j.1365-3059.2007.01775.x

Seko Y., Heluta V., Grigaliūnaitè B., Takamatsu S. 2011. Morphological and molecular characterization of two ITS groups of Erysiphe (Erysiphales) occurring on Syringa and Ligustrum (Oleaceae). Mycoscience, 52(3): 171-182.

Sharma Sh., Khan T.A., Ashraf M.Sh. 2011. Studies on powdery mildew disease of mulberry (Morus alba): a new report from Uttar Pradesh, India. Archives of Phytopathology and Plant Protection, 44(2): 105-112.

Shin H.D. 2000. Erysiphaceae of Korea. Suwon: Nat. Inst. Agric. Sci. Tech., 320 pp.

Shovkovytsya bila. 1992. In: Likarski roslyny: Entsyklopedychnyi dovidnyk. Ed. A.M. Hrodzinskyi Kyiv: Ukrainska Entsyklopediya; Ukrainskyi vyrobnychokomertsiynyi tsentr "Olimp", pp. 479-480. [Шовковиця біла. 1992. У кн.: Лікарські рослини: Енииклопедичний довідник. Відп. ред. А.М. Гродзінський. Київ: Українська енциклопедія; Український виробничокомерційний центр "Олімп", с. 479-480].

Simonyan S.A. 1994. Mikoflora Armenii, vol. 7. Muchnistorosyanye griby Armenii (por. Erysiphales). Erevan: Izdatelstvo AN Armenii, 385 pp. [Симонян C.A. 1994. Микофлора Армении, т. 7. Мучнисторосяные грибы Армении (nop. Erysiphales). Ереван: Издательство АН Армении, $385 \mathrm{c}$ ].

Takamatsu S., Inagaki M., Niinomi S., Khodaparast S.A., Shin H. D., Grigaliūnaitė B., Havrylenko M. 2008. Comprehensive molecular phylogenetic analysis and evolution of the genus Phyllactinia (Ascomycota: Erysiphales) and its allied genera. Mycological Research, 112: 299-315.

Vajna L., Fischl G., Kiss L. 2004. Erysiphe elevata (syn. Microsphaera elevata), a new North American powdery mildew fungus in Europe infecting Catalpa bignonioides trees. Plant Pathology, 53: 244.

Vasyagina M.P., Kuznetsova M.N., Pisareva M.F., Shvartsman S.R. 1961. Flora sporovykh rasteniy 
Kazakhstana, vol. 3. Muchnistorosyanye griby. AlmaAta: Izd-vo AN KazSSR, 460 pp. [Васягина М.П., Кузнецова М.Н., Писарева М.Ф., Шварцман С.Р. 1961. Флора споровых растений Казахстана, т. 3. Мучнисторосяные грибы. Алма-Ата: Изд-во АН КазССР, 460 c.].

Vitenko V.A. 2008. Naukovyi visnyk NLTU Ukrainy, 18(1): 17-22. [Вітенко В.А. 2008. Morus alba L. - цінна плодова, декоративна та лікарська рослина. Науковий вісник НЛТУ України, 18(1): 17-22].
Wang J.-J., Yang L., Qiu X., Fan R., Ao X., Zhou W., Li J.-H., Zhao D.-Y., Wan Y.-J. 2014. Powdery mildew on mulberry in Yunnan, China is distinct from other Phyllactinia spp. on Morus. Journal of Phytopathology, 162: 377-386. https://doi.org/10.1111/jph.12199

Zimmermannová-Pastirčáková K., Adamska I., Blaszkowski J., Bolay A., Braun U. 2000. Epidemic spread of Erysiphe flexuosa (North American powdery mildew of horsechestnut) in Europe. Schlechtendalia, 8: 39-45.

Рекомендує до друку В.П. Гайова

Гелюта В.П., Коритнянська В.Г. 2021. Перша знахідка Phyllactinia moricola (Erysiphales, Ascomycota) на Morus alba в Європі. Украӥнський ботанічний журнал, 78(4): 274-281.

Інститут ботаніки ім. М.Г. Холодного НАН України, вул. Терещенківська 2, Київ 01601, Україна: В.П. Гелюта. Національний науково-дослідний реставраційний центр України, Одеська філія, пр. Вознесенський 7, Одеса 65058 , Україна: В.Г. Коритянська.

Реферат. Повідомляється про знахідку нового для України чужоземного борошнисторосяного гриба Phyllactinia moricola. Його телеоморфа була зареєстрована в жовтні-грудні 2020 р. на Morus alba в Одесі. Наводиться опис дослідженого матеріалу, подаються ілюстрації. Хвороба, що викликається цим видом, може значно знижувати декоративні властивості шовковиці - рослини, що часто використовується в зелених насадженнях населених пунктів України. Зазначається, що гриб може потрапити до Південної Європи, де завдаватиме значних збитків садівництву та виробництву шовку.

Ключові слова: адвентивний вид, борошниста роса, інвазія, Україна, шовковиця 


\title{
Рослинність Дністровського каньйону та оцінка її адаптивного потенціалу
}

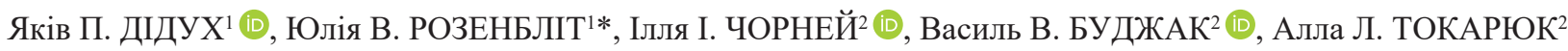 \\ ${ }^{1}$ Інститут ботаніки ім. М.Г. Холодного НАН України вул. Терещенківська 2, Київ 01601, Україна \\ ${ }^{2}$ Чернівецький національний університет ім. Ю. Федьковича, вул. Коцюбинського 2, Чернівці 58012, Україна
}

\begin{abstract}
Syntaxonomy of the natural vegetation of the Dniester Canyon, including 20 classes, 30 orders, 44 alliances, and 71 associations, is presented. The natural vegetation of the canyon is formed by communities of the classes CarpinoFagetea sylvaticae, Quercetea pubescentis, Quercetea robori-petraeae, Alno glutinosae-Populetea albae, CrataegoPrunetea, Festuco-Brometea, Trifolio-Geranietea sanguine, Molinio-Arrhenatheretea, Sedo-Scleranthetea, PhragmitoMagnocaricetea, Bolboschoenetea maritimi, and Isoëto-Nanojuncetea. Grassland vegetation is characterized by the highest syntaxonomic diversity. Quantitative assessment of syntaxonomic diversity in the three-dimensional system of ecological strategies of species according to Ramensky-Grime (CRS) was carried out. Adaptive capabilities, i.e. the potential for possible further development of forest, shrub and grassland habitats, have been assessed. It has been found that the dynamics of forest shrub, grass meadow and steppe communities is determined by successive endoecogenetic processes. In petrophytic communities, fluctuation changes are not manifested and successional changes are rather limited. Significant fluctuations are inherent in floodplain grasslands that depend on the sharp variability of moisture during the growing season. At the same time, it is emphasized that actual realization of these processes depends on influences of external drivers that can be considered as regulatory factors in possible development of syntaxa.
\end{abstract}

Keywords: adaptation, Dniester Canyon, ecological strategies, successions, syntaxonomy, vegetation

Article history. Submitted 25 June 2021. Revised 23 July 2021. Published 30 August 2021

Citation. Didukh Ya.P., Rozenblit Yu.V., Chorney I.I., Budzhak V.V., Tokariuk A.I. 2021. Vegetation of the Dniester Canyon and assessment of its adaptive potential. Ukrainian Botanical Journal, 78(4): 282-296 [In Ukrainian]. https:// doi.org/10.15407/ukrbotj78.04.282

Affiliation. M.G. Kholodny Institute of Botany, National Academy of Sciences of Ukraine, 2 Tereshchenkivska Str., Kyiv 01601, Ukraine: Ya.P. Didukh, Yu.V. Rozenblit. Yuriy Fedkovych Chernivtsi National University, 2 Kotsyubynsky Str., Chernivtsi 58012, Ukraine: I.I. Chorney, V.V. Budzhak, A.I.Tokariuk.

*Corresponding author (e-mail: vuliya.rozenblit@.gmail.com)

\section{Вступ}

Можлива реакція рослинних угруповань на зміни зовнішніх факторівхочаізалежитьвідвпливуостанніх, однак визначається і внутрішньою організацією ценозу, його адаптивними можливостями, які реалізуються у відповідь на зовнішні умови. Традиційно зміни внутрішньої структури ценозів грунтуються на уявленнях про сукцесії, однак при цьому недооцінюються інші механізми, процеси (флуктуаційні, філценогенетичні), які визначаються різноманітною поведінкою видів, що характеризуються різними типами екологічних стратегій. Саме цей аспект оцінки зміни внутрішньої структури ценозів було апробовано на основі синтаксономічного різноманіття Дністровського каньйону.

Дністровський каньйон - це унікальний природно-територіальний комплекс у середній течії долини річки Дністер, де вона перетинає Подільську височину. Складність геологоморфологічної структури каньйону, що

(C) 2021 Ya.P. Didukh, Yu.V. Rozenblit, I.I. Chorney, V.V. Budzhak, A.I. Tokariuk. Published by the M.G. Kholodny Institute of Botany, NAS of Ukraine. This is an open access article under the terms of the Creative Commons Attribution License (http://creativecommons.org/licenses/by/4.0/), which permits use, distribution, and reproduction in any medium, provided the original work is properly cited 
обумовлена загальною розчленованістю території, меандруючим характером русла, багатовіковою геологією підстилаючих порід, крутизною та експозиціями схилів визначає різнотипність поєднання ландшафтних, кліматичних, грунтових i флористичних компонентів. За геоботанічним районуванням України територія Дністровського каньйону розташована в межах ПокутськоМедоборського округу ПівденнопольськоїЗахідноподільської підпровінції широколистяних лісів, лук, лучних степів та евтрофних боліт Центральноєвропейської провінції широколистяних лісів Свропейської широколистянолісової області та Центральноподільського округу Східноєвропейської лісостепової провінції (Didukh, Shelyah-Sosonko, 2003). Таке розташування території в межах двох геоботанічних областей відображає зональнорегіональні особливості регіону, на які накладається геоморфологічна специфіка рельєфу, що в комплексі визначає високу різноманітність, строкатість та специфіку рослинних угруповань. Зважаючи на це, рослинність каньйону нами використана як модель для апробації методики оцінки різноспрямованості можливих змін, які визначаються на основі співвідношень флористичного складу видів у синтаксонах за показниками екологічної стратегії Раменського-Грайма.

\section{Матеріали та методи}

Основу роботи складають матеріали польових досліджень, проведених у 2014-2017 pp. Геоботанічні описи виконували із застосуванням еколого-флористичних критеріїв опису рослинних угруповань (Braun-Blanquet, 1964; Yunatov, 1964; Aleksandrova, 1969; van Der Maarel, 2004) на ділянках, відносно однорідних щодо структури, видового складу та екологічних умов. Описи трав'яних угруповань (лучно-степових, лучних, чагарникових) виконувалися на ділянках розміром $10 \times 10$ м, а прибережно-водної й наскельної, залежно від конфігурації ценозів - на площі до $5 \times 5$ м. Для лісових ценозів ділянки мали розміри $25 \times 25$ м. За допомогою GPS-навігатора фіксували координати центрів цих ділянок. У ході виконання опису вказували експозицію, крутизну схилів, висоту над рівнем моря, будову ярусів, загальне проективне покриття угруповань та окремих видів, умови місцезростання. Криптогамні рослини наведені частково у геоботанічних описах наскельної рослинності. Проективне покриття в описі вказували у відсотках для кожного виду окремо 3 подальшим перетворенням їх у бали за шкалою: $1-\leq 1 \%, 2-$ $2-5 \%, 3-6-20 \%, 4-21-50 \%, 5->50 \%$.

Формування бази даних геоботанічних описів здійснено в програмі Turboveg 2.0. (Hennekens, Schaminee, 2001; Hennekens, 2009), обробку описів та класифікацію рослинності - в середовищі програми JUICE (Tichý, 2002) із застосуванням модифікованого методу двостороннього аналізу індикаторних видів (Modified TWINSPAN Classification) (Roleček et al., 2009).

Виділені кластери ідентифікували на основі "Hierarchical floristic classification system of plant, lichen, and algal communities" (Mucina et al., 2016) та Продромусу рослинності України (Dubyna et al., 2019) а також характеристик окремих синтаксонів (Didukh, Korotchenko, 1997; Abduloieva, Didukh, 1999; Abduloieva, 2002; Korotchenko, 2004; Kozak, 2012; Onyshschenko, 2009; Vasheniak, 2013, 2016; Eliáš, 2017; Hrivnák et al., 2019).

Назви таксонів вищих судинних рослин подано переважно за Vascular plants of Ukraine. A nomenclatural checklist (Mosyakin, Fedoronchuk, 1999).

При формуванні класифікаційної схеми рослинності Дністровського каньйону також враховано опубліковані раніше відомості про ценотичне різноманіття території досліджень (Solodkova et al., 1986; Didukh, Korotchenko, 1997; Abduloieva, Didukh, 1999; Abduloieva, 2002; Korotchenko, 2004; Fitsaylo, 2007, 2014, 2016; Kozak, 2012; Vasheniak, 2013, 2016; Budzhak et al., 2016; Didukh et al., 2018a, b; Didukh, Vasheniak, 2011, 2012, 2018; Dubyna et al., 2019; Goncharenko et al., 2020; Vashenyak et al., 2021).

Кількісний розподіл видів за екологічними стратегіями Раменського-Грайма (Grime, 1974, 1979) виділених синтаксонів проводили за методикою Я.П. Дідуха, суть якої полягає у розрахунку "центру маси" відповідних показників по відношенню до вершин C, R, S. Підрахунок кількості видів кожного типу стратегії для конкретних описів проводився за формулою: $\mathrm{S}_{\mathrm{S}}=\mathrm{S}+(\mathrm{CS} / 2)+(\mathrm{SR} / 2)+(\mathrm{CRS} / 3) ; \mathrm{C}_{\mathrm{C}}$ $=\mathrm{C}+(\mathrm{CS} / 2)+(\mathrm{CR} / 2)+(\mathrm{CRS} / 3) ; \mathrm{R}_{\mathrm{R}}=\mathrm{R}+(\mathrm{CR} / 2)+$ $(\mathrm{RS} / 2)+(\mathrm{CRS} / 3)$. Далі розраховано середні значення та квадратичні відхилення (сигми) для синтаксонів, а також співвідношення між показниками: $\mathrm{S}_{\mathrm{S}}: \mathrm{C}_{\mathrm{C}}$; $\mathrm{R}_{\mathrm{R}}: \mathrm{C}_{\mathrm{C}} ; \mathrm{S}_{\mathrm{S}}: \mathrm{R}_{\mathrm{R}}$ та пропорції C:S:R=1,0:X:Y. Отримані показники (у відсотках) співвідношень відобража- 
лися на сторонах трикутника Дж.Ф. Грайма (Grime's C-S-R Triangle), де вершини відповідають 100\%. По лінії $\mathrm{C}-\mathrm{S}$ точка $\mathrm{C}_{\mathrm{C}}=100 \mathrm{C}_{\mathrm{C}} /\left(\mathrm{C}_{\mathrm{C}}+\mathrm{S}_{\mathrm{S}}\right)$, тоді положення $\mathrm{S}_{\mathrm{S}}$ $=100-\mathrm{C}_{\mathrm{C}}$. По лінії $\mathrm{C}-\mathrm{R}$ положення $\mathrm{R}_{\mathrm{R}}=100 \mathrm{R}_{\mathrm{R}} /\left(\mathrm{R}_{\mathrm{R}}+\right.$ $\mathrm{C}_{\mathrm{C}}$ ), тоді точка $\mathrm{C}_{\mathrm{C}}=100-\mathrm{R}_{\mathrm{R}}$. По лінії $\mathrm{S}-\mathrm{R}$ положення $\mathrm{S}_{\mathrm{S}}=100 \mathrm{~S}_{\mathrm{S}} /\left(\mathrm{S}_{\mathrm{S}}+\mathrm{R}_{\mathrm{R}}\right)$; тоді точка $\mathrm{R}_{\mathrm{R}}=100-\mathrm{S}_{\mathrm{S}}$. Точки наносилися на сторони трикутника i з'єднувалися. На основі таких зображень (рисунки) визначалися "центри мас" трикутника (а), що відповідають точці перетину його медіан, що приурочені до відповідних полів (b). Зони ("мертві поля"), в які навіть теоретично не можуть потрапити "центри мас", позначені штриховкою (с).

\section{Результати та обговорення}

Синтаксономічна схема природної рослинності Дністровського каньйону складена нами на основі власних геоботанічних описів (підкреслено), а також раніше опублікованих праць i представлена 20 класами, 30 порядками, 44 союзами, 71 асоціацією та 6 нетипіфікованими угрупованнями, що хоча й не вичерпують всього фітоценотичного різноманіття, але достатньо повно репрезентують рослинність каньйону.

\section{Лісові угруповання}

Cl. Carpino-Fagetea sylvaticae Jakucs Ex Passarge 1968

Ord. Fagetalia sylvaticae Pawłowski 1928

All. Fagion sylvaticae Luquet 1926

Ass. Stellario holosteae-Fagetum Onyshchenko 2009

Ord. Carpinetalia betuli P.Fukarek 1968

All. Carpinion betuli Issler 1931

Ass. Isopyro thalictroidis-Carpinetum Onyshchenko 1988

Ass. Tilio cordatae-Carpinetum Traczyk 1962

Ass. Waldsteinio-Carpinetum (Jakucs et Jurko, 1967) Soó 1971

Ord. Aceretalia pseudoplatani Moor 1976

All. Tilio-Acerion Klika 1955

Ass. Mercuriali perennis-Fraxinetum excelsioris (Klika 1942) Husová in Moravec et al. 1982 nom. Bayrak 1996 (art. 31)

Ass. Aceri platanoidis-Fraxinetum excelsioris Onyshchenko 1998

All. Melico-Tilion platyphyllis Passarge 1968
Cl. Quercetea pubescentis Doing-Kraft ex Scamoni et Passarge 1959

Ord. Quercetalia pubescenti-petraeae Klika 1933

All. Quercion petraeae Issler 1931

Ass. Seslerio heufleranae-Quercetum petraeae Šomšák et Háberová 1979

All. Betonico officinalis-Quercion roboris

Goncharenko et Semenishchenkov 2020

Ass. Galio tinctoriae-Quercetum roboris Goncharenko 2003

All. Quercion pubescenti-petraeae Br.-B1. 1932

Ass. Corno-Quercetum Máthé \& Kovács 1962

Cl. Quercetea robori-petraeae Br.-Bl. et Tx. ex Oberd. 1957

Ord. Quercetalia roboris Tx. 1931

All. Agrostio-Quercion petraeae Scamoni et Passarge 1959

Ass. Genisto pilosae-Quercetum petraeae Zólyomi et al. Soó 1963

Cl. Alno glutinosae-Populetea albae P. Fukarek \& Fabijanić 1968

Ord. Alno-Fraxinetalia excelsioris Passarge 1968

All. Fraxino-Quercion roboris Passarge 1968

All. Alnion incanae Pawłowski 1928

Ass. Ficario-Ulmetum minoris Knapp 1942 emend. J.Matuszkiewicz

Ass. Carici remotae-Fraxinetum excelsioris Koch ex Faber 1936

Cl. Salicetea purpureae Moor 1958

Ord. Salicetalia purpureae Moor 1958

All. Salicion albae Soó 1951

Ass. Salicetum albae Issler 1926

Cl. Robinietea Jurko ex Hadač et Sofron 1980

Ord. Chelidonio-Robinietalia pseudoacaciae Jurko ex Hadač et Sofron 1980

All. Balloto nigrae-Robinion pseudoacaciae Hadač et Sofron 1980

Ass. Chelidonio-Pinetum sylvestris (Gorelov 1997) Davydov nom. inv.

All. Chelidonio majoris-Robinion pseudoacaciae Hadač et Sofron ex Vítková in Chytrý 2013

Ass. Chelidonio majoris-Robinietum pseudoacaciae Jurko 1963

\section{Чагарникові угруповання}

Cl. Crataego-Prunetea Rivas Goday et Carb. 1961

Ord. Prunetalia spinosae R.Tx. 1952

All. Prunion spinosae Soó (1931) 1940 
Ass. Swido sanguinei-Crataegetum leiomonogynae Fitsailo 2005

Ass. Prunetum spinosae Soó (1931) 1940

All. Berberidion vulgaris Br.-B1. 1950

Ass. Pado-Coryletum Moor 1958

Ass. Roso vosagiacae-Coryletum Oberd. 1957

Ass. Corno-Prunetum spinosae (R.Tx. 1952) Wittig 1975

Ass. Rhamno-Cornetum sanguinei Pass. (1957) 1963

Ass. Lembotropido nigricantis-Cornetum maris Fitsailo 2016

Comm. Caragana frutex

Comm. Spiraea polonica

All. Lamio purpureae-Acerion tatarici Fitsailo 2007

\section{Cl. Salicetea purpureae Moor 1958}

Ord. Salicetalia purpureae Moor 1958

All. Salicion triandrae T. Müller et Görs 1958

Ass. Salicetum triandrae Malcuit ex Noirfalise in Lebrun et al. 1955

All. Rubo caesii-Amorphion fruticosae Shevchyk et Solomakha 1996

\section{Трав'яні угруповання}

Cl. Festuco-Brometea Br.-B1. et Tx. ex Soó 1947

Ord. Festucetalia valesiacae Soó 1947

All. Festucion valesiacae Klika 1931

Ass. Koelerio macranthae-Stipetum joannis Chytrý 2007

Ass. Stipetum pulcherrimae Soó 1942

Ass. Potentillo-Stipetum capillatae Libb. 1933 em. Krausch 1960

Ass. Botriochloetum ischaemi (Kristinsson 1937) I. Pop 1977

Ord. Brachypodietalia pinnati Korneck 1974

All. Cirsio-Brachypodion pinnati Hadač et Klika in Klika et Hadač 1944

Ass. Inuletum ensifoliae Kozłowska 1925

Ass. Orchido militaris-Seslerietum heufleranae

Schneider ex Dengler et al. 2012

Ass. Origano-Brachypodietum pinnati Medw.-Korn. et Kornas 1963

Ass. Seslerietum heuflerianae Soó 1947

Ass. Asteri-Linetum flavae Glaczek 1968

Ass. Carici humilis-Festucetum valesiacae Klika 1951

All. Fragario viridis-Trifolion montani Korotchenko \& Didukh 1997

Ass. Thalictro-Salvietum pratensis MedweckaKornaś 1959
Ass. Thymo marschalliani-Caricetum praecocis Korotchenko et Didukh 1997

Ass. Salvio pratensis-Poetum angustifoliae

Korotchenko \& Didukh 1997

All. Artemisio marschallianae-Elytrigion intermediae Korotchenko et Didukh 1997

Ass. Salvio nemorosae-Elytrigietum intermediae

Abduloyeva 2002

Ord. Stipo pulcherrimae-Festucetalia pallentis Pop 1968

All. Galio campanulatae-Poion versicoloris Kukovitsa, Movchan, V.Solomakha et Shelyag ex Didukh et Mucina in Mucina et al. 2013

Ass. Schivereckio podolicae-Seselietum libanotidis Didukh et Vasheniak 2017

Ass. Poetum versicoloris Kukovitsa et al. 1992

Ass. Melico transsilvanicae-Lembotropetum nigricantis Korotchenko 2004

Ass. Thymo moldavici-Seselietum hippomaranthrae Pinzaru 2006 corr. Vasheniak et Didukh 2018

Cl. Molinio-Arrhenatheretea Tx. 1937

Ord. Galietalia veri Mirkin et Naumova 1986

All. Agrostion vinealis Sipaylova et al. 1985

Ass. Festuco valesiacae-Poetum angustifoliae

Mirkin in Denisova et al. 1986

Ord. Arrhenatheretalia elatioris Tx. 1931

All. Arrhenatherion elatioris Luquet 1926

Ass. Festucetum pratensis Soó 1938

Ass. Poëtum pratensis Ravarut et al. 1956

All. Cynosurion cristati Tx. 1947

Ass. Lolio perennis-Cynosuretum cristati Tx. 1937

Ord. Molinietalia caeruleae Koch 1926

All. Calthion palustris Tx. 1937

Ass. Scirpetum sylvatici Ralsky 1931

All. Filipendulion ulmariae Segal ex Westhoff et DenHeld 1969

Ass. Lysimachio vulgaris-Filipenduletum ulmariae Balotova-Tulachova 1971

All. Molinion caeruleae Koch 1926

Comm. Palusturiella commutata-Agrostis stolonifera

Comm. Molinia arundinacea

Comm. Agrostis stolonifera

Comm. Eupatorium cannabinum

Cl. Trifolio-Geranietea Th.Müller 1962

Ord. Origanetalia vulgaris T. Müller 1962

All. Trifolion medii T. Müller 1962

Ass. Vicietum sylvaticae Oberd. et T.Müller in T.Müller 1962 
Ord. Antherico ramosi-Geranietalia sanguinei Julve ex Dengler in Dengler et al. 2003

All. Geranion sanguinei Tx. in T.Müller 1962

Ass. Geranio-Dictamnetum Wendelberger ex T.Müller 1962

Ass. Trifolio alpestris-Melampyretum cristati Rameau 1974

Ass. Geranio sanguinei-Trifolietum alpestris T.Müller 1962

Cl. Plantaginetea majoris Tx. et Preising ex von Rochow 1951

Ord. Potentillo-Polygonetalia avicularis Tx. 1947

All. Potentillion anserinae Tx. 1947

Ass. Rumici crispi-Agrostietum stoloniferae Moor 1958

Ass. Potentilletum anserinae Rapaics 1927

\section{Петрофітні угруповання}

Cl. Sedo-Scleranthetea_Br.-Bl. 1955

Ord. Alysso-Sedetalia Moravec 1967

All. Alysso-Sedion Oberdoferet Müller in Müller 1961

Ass. Aurinio saxatilis-Allietum podolici Onyschenko 2001

Ass. Bryo argentei-Ajugetum chiae Didukh et Vasheniak 2017

Ass. Alysso alyssoidis-Sedetum Oberdofer et Th.Müller in Müller 1961

Cl. Asplenietea trichomanis_(Br.-B1. 1934) Oberdorfer 1977

Ord. Potentilletalia caulescentis Br.-Bl. in Br.-Bl. et Jenny 1926

All. Potentillion caulescentis Br.-Bl. in Br.-Bl. et Jenny 1926

Ass. Asplenietum trichomano-rutae-murariae Kuhn 1937

Ord. Ctenidio-Polypodietalia Jurko et Pecier ex Boscaiu, Gargely et Cotoreanu in Patiu et al. 1966

All. Ctenidio-Polypodion vulgare Jurko et Pecier ex Boscaiu, Gargely et Cotoreanu in Patiu et al. 1966

Ass. Ctenidio-Polypodietum Jurko et Peciar 1963 (Asplenio-Phyllidetum scolopendrii Redzic et al. 2002)

Cl. Verrucarietea nigrescentis Wirth 1980

Ord. Verrucarietalia nigrescentis Klement 1950

All. Aspicillion calcareae Albertson 1946 ex Routx 1978

All. Caloplacion decipientis Klem 1950

\section{Прибережно-водна рослинність}

Cl. Phragmito-Magnocaricetea Klika in Klika et Novak 1941

Ord. Oenanthetalia aquaticae Hejný ex BalátováTuláčková et al. 1993

All. Eleocharito palustris-Sagittarion sagittifoliae Passarge 1964

Ass. Butometum umbellati Philippi 1973

Ass. Eleocharitetum palustris Savič 1926

Ord. Phragmitetalia australis W.Koch 1926

All. Phragmition communis Koch 1926

Ass. Iridetum pseudacori Eggler 1933

Ass. Phragmitetum communis Savič 1926

Ass. Typhetum angustifoliae Pignatti 1953

Ord. Nasturtio-Glycerietalia Pignatti 1953

All. Phalaridion arundinaceae Kopecký 1961

Ass. Phalaridetum arundinaceae Libbert 1931

Cl. Bolboschoenetea maritimi Vicherek et Tx. in Tx. et Hülbusch 1971

Ord. Bolboschoenetalia maritimi Hejný in Holub et al. 1967

All. Scirpion maritimi Dahl et Hadač 1941

Ass. Bolboschoenetum maritimi Eggler 1933

Cl. Isoëto-Nanojuncetea Br.-Bl. et Tx. in Br.-Bl. et al. 1952

Ord. Nanocyperetalia Klika 1935

All. Eleocharition soloniensis Philippi 1968

Ass. Cyperetum micheliani Horvatić 1931

Ass. Juncetum bufonii Felföldy 1942

Cl. Bidentetea tripartitae Tx. et al. ex von Rochow 1951

Ord. Bidentetalia Br.-B1. et Tx. ex Klika et Hadač 1944

All. Bidention tripartitae Nordhagen ex Klika et Hadač 1944

Ass. Polygonetum hydropiperis Passarge 1965

Ass. Bidentetum tripartitae Miljan 1933

Ass. Bidentetum frondoso-connatae Makhynya 2015

Cl. Montio-Cardaminetea Br.-Bl. et Tx 1943

Ord. Montio-Cardaminetalia Pawlowski 1928

All. Lycopo-Cratoneurion commutati Hadac 1983

$(=$ Pellio endiviifoliae-Cratoneurion commutati Rivola 1992)

Ass. Cratoneuretum filicino-commutatae (Oberdorfer 1977)

Переважаючим типом рослинності в каньйоні $\epsilon$ неморальні широколистяні ліси класу CarpinoFagetea sylvaticae (порядки Fagetalia sylvaticae, Carpinetalia betuli, Aceretalia pseudoplatani), серед яких найбільшу площу займають дубово-грабові 
ліси порядку Carpinetalia betuli, поширені переважно у північній частині каньйону по обидва берега Дністра. Особливої уваги заслуговує асоціація Waldsteinio-Carpinetum (Jakucs et Jurko, 1967) Soy 1971, яка раніше в літературі для території України не наводилася. Нами виявлені ії ділянки на лівому березі Дністра та його приток, де Waldsteinia geoides Willd. є домінантом трав'яного ярусу, а діагностичними видами виступають Helleborus purpurascens Waldst. \& Kit., Dryopteris filix-mas (L.) Schott, Milium effusum L., Lonicera xylosteum L. Букові ліси порядку Fagetalia sylvaticae знаходяться на східній межі ареалу та трапляються в Дністровському каньйоні окремими острівцями. Специфікою досліджуваного регіону $\epsilon$ наявність угруповань термофільних (Quercetea pubescentis) і ацидофільних (Quercetea robori-petraeae) дібров, що займають опуклі добре прогріті крутосхили. Ацидофільні діброви (Genisto pilosae-Quercetum petraeae) відмічені нами невеликими фрагментами поблизу c. Зелений Гай Тернопільської області (заказник Жижавський) і на території РЛП "Дністровський" та НПП "Хотинський" (неопубліковані дані I.I. Чорнея, В.В. Буджака, А.І. Токарюк). Заплавні тополеві, вербові ліси належать до класів Salicetea purpureae, Alno glutinosae-Populetea albae та досить часто трапляються на перших надзаплавних терасах Дністра.

Слід відзначити, що в складі лісових угруповань трапляється низка видів з Червоної книги України (Chervona knyha..., 2009) (Aconitum besserianum Andrz. ex Trautv., Allium ursinum L., Cephalanthera longifolia (L.) Fritsch, C. rubra (L.) Rich., Epipactis helleborine (L.) Crantz, E. purpurata Smith, Fritillaria montana Hoppe, Galanthus nivalis L., Lathyrus venetus (Mill.) Wohlf., Lilium martagon L., Neottia nidus-avis (L.) Rich., Platanthera bifolia (L.) Rich., Scopolia carniolica Jacq., Sorbus torminalis (L.) Crantz (Torminalis glaberrima (Gand.) Sennikov \& Kurtto), Staphylaea pinnata L., Waldsteinia geoides L. та ін.), що свідчить про їхню созологічну цінність.

Чагарникові ценози належать до класу CrataegoPrunetea. На схилах каньйону вони представлені союзами Berberidion vulgaris (займають відкриті, прогріті ділянки), Lamio purpureae-Acerion tatarici (узлісні угруповання, що не утворюють великих масивів) та степові чагарники союзу Prunion spinosae, які утворюють густі зарості на схилах балок зі змитими грунтами. Зокрема, вперше було зафіксовано локальні угруповання 3 домінуванням
Caragana frutex. У зв'язку із затопленням заплави відмічено інтенсивне поширення Amorpha fruticosa, що заселяс тріщини скель із достатнім зволоженням. (all. Rubo caesii-Amorphion fruticosae Shevchyk et Solomakha 1996).

Маргінальну рослинність формують термофільні угруповання класу Trifolio-Geranietea (порядки Origanetalia vulgaris та Antherico ramosi-Geranietalia sanguineae), які переважно займають екотонні ділянки між лучно-степовою та лісовою рослинністю.

Найбільш різноманітною на схилах каньйону $\epsilon$ степова рослинність класу Festuco-Brometea. Угруповання порядку Festucetalia valesiacae це типові ксерофітні степові угруповання 3 домінуванням Stipa capillata L., S. pulcherrima K.Koch, S. pennata L., Festuca valesiaca Gaudin, Botriochloa ischaemum (L.) Keng та Elytrigia intermedia (Host) Nevski). У ценозах порядку Brachypodietalia pinnati, сформованих в мезоксерофільних умовах, домінують Brachypodium pinnatum (L.) P.Beauv., Carex humilis Leys, Sesleria heufleriana Schur. Петрофітні степи порядку Stipo pulcherrimae-Festucetalia pallentis характеризуються домінуванням Poa versicolor Besser, Seseli hippomarathrum Jacq. тощо.

Лучна рослинність Дністровського каньйону належить до класу Molinio-Arrhenatheretea (порядки Arrhenatheretalia elatioris, Molinietalia caeruleae, Galietalia veri). Угруповання найбільш сухих для класу умов займають більш-менш вирівняні ділянки 3 легким супіщаним грунтом, що добре дренується, належать до порядку Galietalia veri та представлені одним союзом Agrostion vinealis. Для цих угруповань характерна присутність значної кількості видів класу Festuco-Brometea у складі ценозів. Типові луки порядку Arrhenatheretalia elatioris досить бідні за флористичним складом і містять значну кількість адвентивних та рудеральних видів. Угруповання фрагментарно поширені в нижній частині пологих лесових схилів. Порядок Molinietalia caeruleae хоча й представлений трьома союзами (Calthion palustris, Filipendulion ulmariae, Molinion caeruleae), однак їхні угруповання трапляються невеликими пасмами на перезволожених місцях, зокрема вздовж струмків та водоспадів (Budzhak et al., 2016; Didukh et al., 2018).

У складі трав'яних типів угруповань також трапляється значна кількість видів, включених до Червоної книги України (2009): Aconitumpseudanthora Blocki ex Pacz., Allium obliquum L., Astragalus monspessulanus L., Chamaecytisus albus (Hacq.) Rothm., Linum basarabicum (Savul. et Raiss.) Klokov ex 
Juz., Pulsatilla grandis Wender., P. pratensis (L.) Mill., Thalictrum foetidum L., Schivereckia podolica (Besser) Andrz. ex DC. (Draba podolica Andrz. ex DC.) Rupr.), Scutellaria verna Besser, Stipa capillata, S. pennata, S. pulcherrima.

На трав'яних схилах місцями на поверхню виходять скелі, де представлені угруповання класу Sedo-Scleranthetea. Значні площі займають стрімкі карбонатні відслонення, на яких формується хазмофітна та епілітна рослинність класу Asplenietea trichomanis (Asplenion rutae-murariae i CtenidioPolypodion vulgare). Наскельні лишайникові угруповання представлені класом Verrucarietea nigrescentis (Aspicillion calcareae, Caloplacion decipientis).

Локальне поширення в середніх частинах схилів, у лісах (вздовж потічків) та на крутих відкритих скельних урвищах (де на поверхню виклинюється вода) мають угруповання класу Montio-Cardaminetea. (Cratoneurion commutati) (Didukh et al., 2018a, b).

Прибережно-водна рослинність включає три класи: Phragmito-Magnocaricetea, Bolboschoenetea maritimi та Isoëto-Nanojuncetea. Угруповання (Iridetum pseudacori, Phragmitetum communis, Typhetum angustifoliae) прируслових ділянок заплави в зоні підтоплення мають обмежене поширення в каньйоні. На ділянках мілководь 3 алювіальними наносами, де відмічене надмірне антропогенне навантаження, а відтак i ценотичне засолення, сформовані угруповання класу Bolboschoenetea maritimi. Угруповання мають дуже локальне поширення.

Угруповання класу Phragmito-Magnocaricetea обмежено поширені в каньйоні та займають прируслові ділянки заплави в зоні підтоплення. Іншу екологічну приуроченість на ділянках мілководдя 3 алювіальними наносами, де відмічене надмірне антропогенне навантаження, а відтак і ценотичне засолення, мають угруповання класу Bolboschoenetea maritimi.

Рудеральна рослинність враховувалась нами лише на екотонних ділянках на межі з природними типами рослинності і представлена класами Plantaginetea majoris, Bidentetea, Robinietea.

Однією 3 особливостей долини р. Дністер $\epsilon$ періодичні підтоплення заплави та забір води під час літнього періоду, що обумовлено роботою Дністровської ГЕС. У таких місцях простежується сильний рекреаційний вплив, тут формуються угруповання класу Isoëto-Nanojuncetea, що розвиваються восени на алювіальних наносах, коли рівень води спадає. Угруповання класу Bidentetea досить часто трапляються у прирусловій частині. Відмічається домінування Bidens frondosa L. у зазначених ценозах, що пов'язане із давньою натуралізацією цього адвентивного виду та його життєвою стратегією.

Отже, найвищою синтаксономічною різноманітністю серед встановлених на території Дністровського каньйону типів рослинності характеризується степова, тоді як найбільші площі зайняті лісовою. Запропонована схема достатньою мірою відображає природну рослинність території дослідження та екологічні особливості умов регіону, проте деякі синтаксони потребують більш детального аналізу, зокрема термофільні й ацидофільні діброви класів Quercetea pubescentis, Quercetea roboripetraeae.

Наступним етапом наших досліджень стало проведення кількісного розрахунку синтаксономічного різноманіття Дністровського каньйону в тримірній системі екологічних стратегій видів РаменськогоГрайма (CRS), що характеризує адаптаційний потенціал, який впливає на характер розвитку екосистем (табл. 1).

Розподіл синтаксонів за екологічними стратегіями та аналіз відповідних процесів подальшого розвитку наведено нами у вигляді графічного зображення на трикутнику Раменського-Грайма (рис. 1, 2).

Аналізуючи відповідні показники розподілу видів у синтаксонах, їхні пропорції та положення "центрів мас", відмітимо, що для типових неморальних лісів показники співвідношень стрес-толерантів становлять $0,02-0,06$, а рудералів - 0,03-0,11 по відношенню до конкурентів. "Центри мас" лісових ценозів знаходяться в зоні сукцесійного розвитку - C (Stellario holosteae-Fagetum, Isopyro thalictroidis-Carpinetum, Waldsteinio-Carpinetum, Mercuriali perennis-Fraxinetum excelsioris, Tilio cordatae-Carpinetum), у решти синтаксонів - у зоні CS чи CR, але ближче до вершини C, ніж інших вершин (за винятком Rubo caesii-Amorphion fruticosae). Це означає, що динаміка лісових $\mathrm{i}$ чагарникових угруповань визначається сукцесійними ендоекогенетичними процесами, пов'язаними із заміщенням домінуючих видів та зміною структури ценозів через вплив зовнішніх едафічних чинників, зокрема опосередкованого впливу на них клімату. При цьому центри мас вологіших тінистих угруповань (Aceri platanoidis-Fraxinetum excelsioris, 
Таблиця 1. Кількісний розподіл флористичного складу синтаксонів Дністровського каньйону за екологічними стратегіями Раменського-Грайма

Table 1. Quantitative distribution of the floristic composition of syntaxa of the Dniester canyon according to Grime's ecological strategies

\begin{tabular}{|c|c|c|c|c|}
\hline \multirow[t]{2}{*}{ Синтаксон } & \multicolumn{3}{|c|}{$\frac{\text { Показники числа видів }}{\% *}$} & \multirow[t]{2}{*}{$\begin{array}{c}\text { Пропорція } \\
\text { C:S:R }\end{array}$} \\
\hline & $\mathrm{C}^{*}$ & $\mathrm{~S}$ & $\mathrm{R}$ & \\
\hline Stellario holosteae-Fagetum & $\frac{33,32 \pm 10,86}{92,72}$ & $\frac{0,53 \pm 0,47}{1,47}$ & $\frac{2,09 \pm 1,45}{5,81}$ & $1: 0,02: 0,06$ \\
\hline Isopyro thalictroidis-Carpinetum & $\frac{36,07 \pm 6,92}{92,69}$ & $\frac{0,69 \pm 0,48}{1,78}$ & $\frac{2,15 \pm 1,39}{5,53}$ & $1: 0,02: 0,06$ \\
\hline Waldsteinio-Carpinetum & $\frac{29,27 \pm 7,38}{93,60}$ & $\frac{0,45 \pm 0,57}{1,45}$ & $\frac{1,55 \pm 1,47}{4,94}$ & $1: 0,02: 0,05$ \\
\hline Mercuriali perennis-Fraxinetum excelsioris & $\frac{22,17 \pm 5,35}{92,47}$ & $\frac{0,40 \pm 0,51}{1,68}$ & $\frac{1,40 \pm 0,88}{5,85}$ & $1: 0,02: 0,06$ \\
\hline Tilio cordatae-Carpinetum & $\begin{array}{c}\frac{23,26 \pm 4,04}{92,00} \\
\end{array}$ & $\frac{1,26 \pm 0,65}{4,99}$ & $\frac{0,76 \pm 0,45}{3,01}$ & $1: 0,05: 0,03$ \\
\hline Aceri platanoidis-Fraxinetum excelsioris & $\begin{array}{c}\frac{26,91 \pm 7,56}{88,30} \\
\end{array}$ & $\frac{0,67 \pm 0,70}{2,21}$ & $\frac{2,89 \pm 1,36}{9,49}$ & $1: 0,03: 0,11$ \\
\hline Melico (nutantis)-Tilion platyphyllis & $\frac{29,58 \pm 7,56}{88,03}$ & $\frac{0,84 \pm 0,68}{2,51}$ & $\frac{3,18 \pm 1,47}{9,46}$ & $1: 0,03: 0,11$ \\
\hline Corno-Quercetum & $\frac{31,70 \pm 12,25}{85,68}$ & $\frac{1,88 \pm 1,04}{5,08}$ & $\frac{3,42 \pm 2,49}{9,23}$ & $1: 0,06: 0,11$ \\
\hline Betonico officinalis-Quercion roboris & $\frac{16,09 \pm 8,02}{85,82}$ & $\frac{2,02 \pm 0,91}{10,76}$ & $\frac{0,64 \pm 1,04}{3,42}$ & $1: 0,13: 0,04$ \\
\hline Genisto pilosae-Quercetum petraeae & $\frac{11,42 \pm 3,85}{77,40}$ & $\frac{2,92 \pm 1,32}{19,77}$ & $\frac{0,42 \pm 0,55}{2,82}$ & $1: 0,26: 0,04$ \\
\hline Seslerio heufleranae-Quercetum petraeae & $\frac{29,70 \pm 9,74}{82,04}$ & $\frac{5,40 \pm 2,27}{14,92}$ & $\frac{1,10 \pm 0,74}{3,04}$ & $1: 0,18: 0,04$ \\
\hline Ficario-Ulmetum minoris & $\frac{9,17 \pm 8,18}{65,48}$ & $\begin{array}{c}\frac{2,25 \pm 2,36}{16,07} \\
\end{array}$ & $\frac{2,58 \pm 2,22}{18,45}$ & $1: 0,25: 0,28$ \\
\hline Carici remotae-Fraxinetum excelsioris & $\frac{37,36 \pm 8,64}{92,08}$ & $\frac{0,96 \pm 0,51}{2,38}$ & $\frac{2,25 \pm 1,37}{5,55}$ & $1: 0,03: 0,06$ \\
\hline Salicetum albae & $\frac{10,13 \pm 1,98}{53,18}$ & $\frac{4,08 \pm 1,43}{21,41}$ & $\frac{4,84 \pm 1,55}{25,41}$ & $1: 0,40: 0,48$ \\
\hline Salicetum triandrae & $\frac{9.96 \pm 2,29}{52,01}$ & $\frac{5,27 \pm 1,74}{27,51}$ & $\frac{3,92 \pm 1,10}{20,48}$ & $1: 0,53: 0,39$ \\
\hline Rubo caesii-Amorphion fruticosae & $\frac{7,54 \pm 3,25}{53,18}$ & $\frac{3,42 \pm 0,73}{22,40}$ & $\frac{4,29 \pm 2,42}{28,14}$ & $1: 0,45: 0,57$ \\
\hline Chelidonio-Pinetum sylvestris & $\frac{10,31 \pm 3,72}{73,61}$ & $\frac{1,56 \pm 0,34}{11,11}$ & $\frac{2,14 \pm 1,26}{15,28}$ & $1: 0,15: 0,21$ \\
\hline Berberidion vulgaris & $\frac{11,56 \pm 2,57}{59,29}$ & $\frac{4,54 \pm 1,41}{23,29}$ & $\frac{3,40 \pm 1,38}{17,41}$ & $1: 0,39: 0,29$ \\
\hline Prunion spinosae & $\frac{6,52 \pm 1,61}{66,67}$ & $\frac{1,41 \pm 0,71}{14,39}$ & $\frac{1,85 \pm 0,75}{18,94}$ & $1: 0,22: 0,28$ \\
\hline Thalictro-Salvietum pratensis & $\frac{26,32 \pm 2,48}{75,62}$ & $\frac{5,32 \pm 2,11}{15,28}$ & $\frac{3,17 \pm 1,38}{9,10}$ & $1: 0,2: 0,12$ \\
\hline Salvio pratensis-Poetum angustifoliae & $\frac{18,95 \pm 3,78}{66,99}$ & $\frac{6,95 \pm 2,17}{24,57}$ & $\frac{2,39 \pm 1,46}{8,44}$ & $1: 0,37: 0,13$ \\
\hline Thymo marschalliani-Caricetum praecocis & $\frac{18,61 \pm 3,89}{70,18}$ & $\frac{5,75 \pm 2,16}{21,67}$ & $\frac{2,16 \pm 1,40}{8,15}$ & $1: 0,31: 0,12$ \\
\hline Botriochloetum ischaemi & $\frac{13,32 \pm 5,74}{60,65}$ & $\frac{5,53 \pm 1,80}{25,17}$ & $\frac{3,11 \pm 2,25}{14,18}$ & $1: 0,42: 0,23$ \\
\hline Thymo moldavici-Seselietum hippomaranthrae & $\frac{12,76 \pm 3,39}{54,81}$ & $\frac{8,65 \pm 2,08}{37,17}$ & $\frac{1,87 \pm 1,01}{8,03}$ & $1: 0,68: 0,15$ \\
\hline Poetum versicoloris subass. Elyerigietosum intermesiae & $\frac{11,50 \pm 2,97}{57,40}$ & $\frac{6,86 \pm 1,91}{34,25}$ & $\frac{1,67 \pm 1,16}{8,35}$ & $1: 0,6: 0,15$ \\
\hline
\end{tabular}




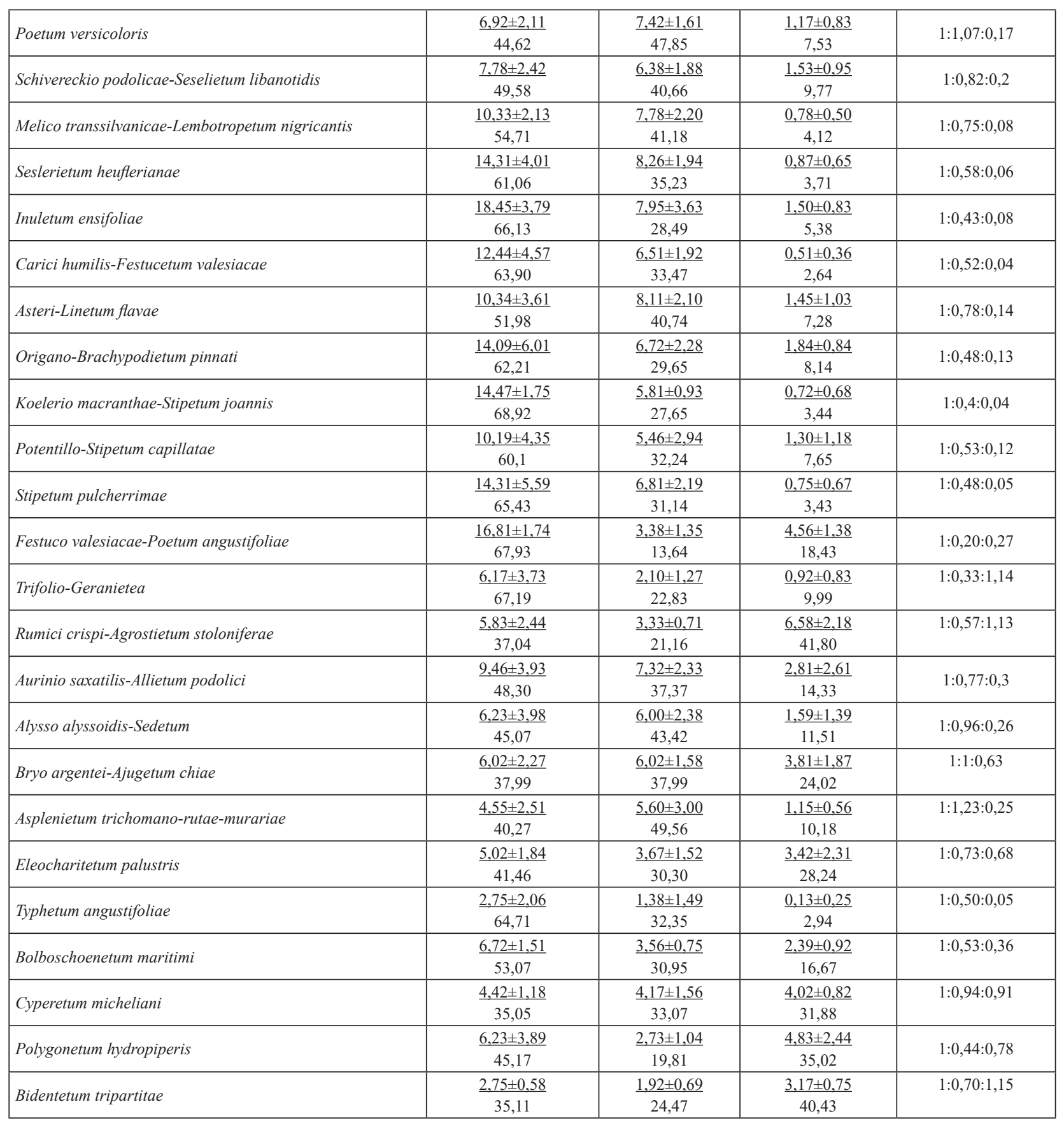

*тут і на рис. 1, 2: С - конкуренти; $\mathrm{S}$ - стрес-толеранти; $\mathrm{R}$ - рудерали

*** чисельнику подано середнє значення числа видів відповідно до стратегій та їхнє квадратичне відхилення; у знаменнику відсоткова частка розподілу видів у синтаксонах за екологічними стратегіями

*here and Figs. 1, 2: C - competitors; $\mathrm{S}$ - stress-tolerants; $\mathrm{R}$ - ruderals.

** numerator shows the average value of the species number according to strategies and their quadratic deviation; denominator shows percentage of species distribution in syntaxa by ecological strategies 


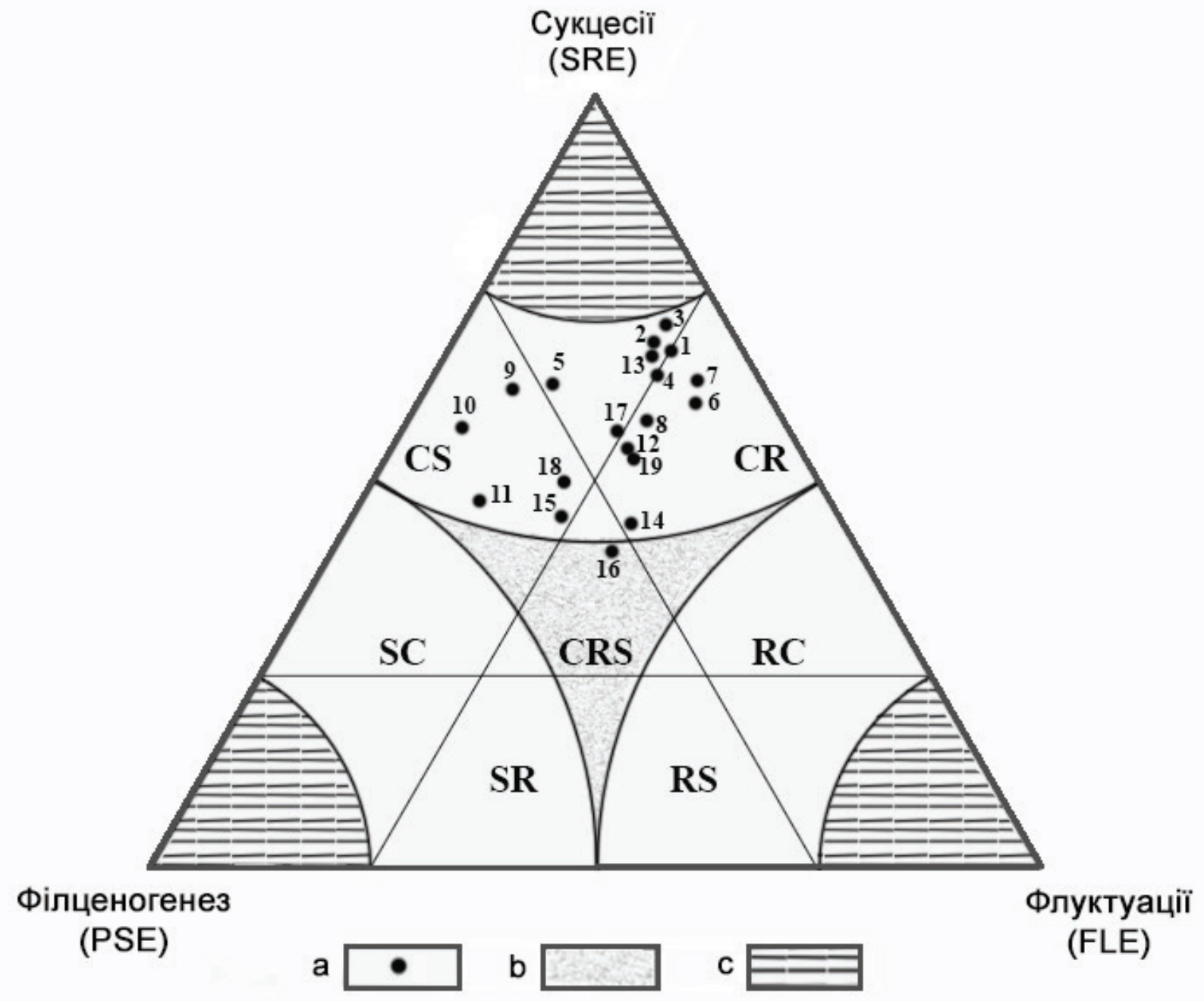

Рис. 1. Розподіл синтаксонів лісової та чагарникової рослинності Дністровського каньйону за екологічними стратегіями Тут і на рис. 2: a - "центри мас"; b - поля відповідного поєднання стратегій; c - "мертві" поля, в які теоретично синтаксони потрапляти не можуть; SRE - сукцесії; FLE - флуктуації; PSE - філценогенез

Синтаксони (Syntaxa): 1 - Stellario holosteae-Fagetum; 2 - Isopyro thalictroidis-Carpinetum; 3 - Waldsteinio-Carpinetum; 4 Mercuriali perennis-Fraxinetum excelsioris; 5 - Tilio cordatae-Carpinetum; 6-Aceri platanoidis-Fraxinetum excelsioris; 7 -Melico (nutantis)-Tilion platyphyllis; 8 - Corno-Quercetum; 9 - Betonico officinalis-Quercion roboris; 10 - Genisto pilosae-Quercetum petraeae; 11 -Seslerio heufleranae-Quercetum petraeae; 12 - Ficario-Ulmetum minoris; 13 -Carici remotae-Fraxinetum excelsioris; 14 - Salicetum albae; 15 - Salicetum triandrae; 16 - Rubo caesii-Amorphion fruticosae; 17 - Chelidonio-Pinetum sylvestris; 18 Berberidion vulgaris; 19 - Prunion spinosae

Fig. 1. Distribution of forest and shrub syntaxa vegetation of the Dniester canyon according to Grime's ecological strategies Here and in Fig. 2: a - "center of mass"; b - zones of combination of strategies; c - "dead" zones; SRE - successions; FLE fluctuations; PSE - phylcoenogenesis 


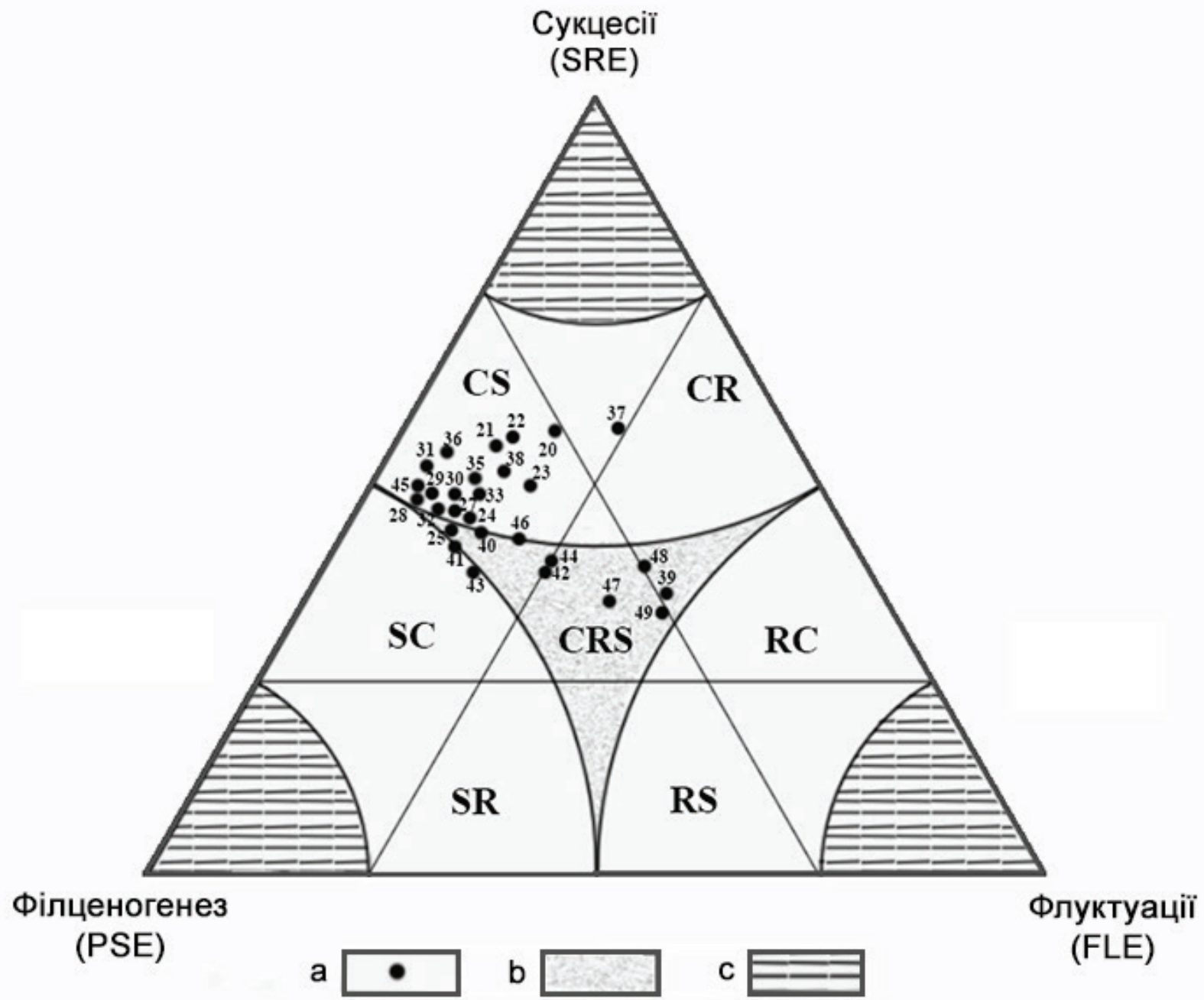

Рис. 2. Розподіл синтаксонів трав'яної рослинності Дністровського каньйону за екологічними стратегіями РаменськогоГрайма (Пояснення див. на рис. 1)

Синтаксони (Syntaxa): 20 - Thalictro-Salvietum pratensis; 21 - Salvio pratensis-Poetum angustifoliae; 22 - Thymo marschallianiCaricetum praecocis; 23 - Botriochloetum ischaemi; 24 - Thymo moldavici-Seselietum hippomaranthrae; 25 - Poetum versicoloris; 27 - Schivereckio podolicae-Seselietum libanotidis; 28 - Melico transsilvanicae-Lembotropetum nigricantis; 29 - Seslerietum heuflerianae; 30 - Inuletum ensifoliae; 31 - Carici humilis-Festucetum valesiacae; 32 - Asteri-Linetum flavae; 33 - OriganoBrachypodietum pinnati; 34 - Koelerio macranthae-Stipetum joannis; 35 - Potentillo-Stipetum capillatae; 36 - Stipetum pulcherrimae; 37 -Festuco valesiacae-Poetum angustifoliae; 38 - Trifolio-Geranietea; 39 - Rumici crispi-Agrostietum stoloniferae; 40 - Aurinio saxatilis-Allietum podolici; 41 - Alysso alyssoidis-Sedetum; 42 - Bryo argentei-Ajugetum chiae; 43 - Asplenietum trichomano-rutae-murariae; 44 - Eleocharitetum palustris; 45 - Typhetum angustifoliae; 46 - Bolboschoenetum maritimi; 47 Cyperetum micheliani; 48 - Polygonetum hydropiperis; 49 -Bidentetum tripartitae

Fig. 2. Distribution of grassland syntaxa of the Dniester canyon according to Grime's ecological strategies (see legend in Fig. 1) 
Melico (nutantis)-Tilion platyphyllis, Corno-Quercetum, Ficario-Ulmetum minoris, Carici remotae-Fraxinetum excelsioris, Salicetum albae) лежать у зоні CR, a освітлених ксерофітних (Betonico officinalis-Quercion roboris, Genisto pilosae-Quercetum petraeae, Seslerio heufleranae-Quercetum petraeae) та перезволожених (Salicetum triandrae) у зоні CS.

Лісові та чагарникові угруповання гідрогенного характеру у заплавах характеризуються більшою участю стрес-толерантів $(0,22-0,53)$ та рудералів $(0,28-0,57)$. Це свідчить про їхню порушеність чи проміжне положення за відношенням до стійкого стану та обмеженість розвитку через вплив певного лімітуючого фактору (надмірне зволоження). У трав'яних степових та петрофітних угрупованнях показники рудерального компонента коливаються від 0,05 до 0,3, що свідчить про незначні зміни флуктуаційного характеру. При цьому узлісні та степові угруповання характеризуються показниками стрес-толерантів 0,2-0,6, що вказує на переважання їхнього розвитку внаслідок сукцесійних змін. Чим мезофітніші угруповання (Thalictro-Salvietum pratensis, Salvio pratensis-Poetum angustifoliae, Thymo marschalliani-Caricetum praecocis), тим положення "центру мас" розташовано ближче до вершини С. Для петрофітних угруповань характерно збільшення ролі стрес-толерантів $(0,6-1,1)$, де можливість сукцесійних змін, судячи за положенням центру мас у зоні C, хоча і проявляється, але вони обмежені характером субстрату, а подальший розвиток зумовлений адаптаційними змінами видів, які визначаються зміною зовнішніх ознак чи фізіологічних процесів, тобто філценогенезом. Ці процеси є значно тривалішими, ніж сукцесійні зміни. Трав'яні (повітряно-водні та рудеральні) угруповання заплав характеризуються ширшим діапазоном наявності стрес-толерантів $(0,4-0,9)$ та рудералів (від 0,05 (Typhetum angustifoliae) до 1,15 (Bidentetum tripartitae)), що свідчить про різнобічний характер їхнього розвитку залежно від впливу зовнішніх факторів (надмірного обводнення) чи варіабельності їхніх змін упродовж сезону, що зумовлює великі флуктуаційні процеси.

Однак слід зауважити, що кількісний аналіз екологічних стратегій Раменського-Грайма відображає лише адаптивні можливості, тобто внутрішній потенціал відповідного синтаксону, реалізація якого залежить від впливу зовнішніх факторів, які виступають бар'єром або регулюючим чинником можливого розвитку. Оцінка взаємодії внутрішнього потенціалу, адаптивних можливостей та зовнішнього впливу визначає можливі зміни відповідних рослинних угруповань.

\section{Висновки}

Як свідчать результати наших досліджень, ценотичне різноманіття Дністровського каньйону $є$ досить високим і загалом відповідає зональним особливостям регіону. Найбільшу кількість ценозів (19 асоціацій) встановлено для степової рослинності класу FestucaBrometea, угруповання яких сформовані в різних умовах ландшафтних структур каньйону. Натомість невисоке ценотичне різноманіття властиве для заплавних лісів (4 асоціації) та угруповань вздовж потоків і струмків класу Montio-Cardaminetea (2 асоціації). Синтаксономічний склад прибережноводної рослинності (11 асоціацій) досить високий, як для регіону, де заплава значною мірою трансформована. Проведений кількісний розподіл усього ценорізноманіття за екологічними стратегіями показав, що розвиток лісових екосистем зумовлений опосередкованою дією кліматичних процесів, заплавних лісових i чагарникових - фактором надмірного зволоження, а петрофітних - едафічних умов. Реалізація цих процесів залежить від впливу зовнішніх факторів, які виступають бар'єром або регулюючим чинником розвитку синтаксонів. Отримані дані важливі для прогнозування можливих змін розвитку фітоценозів у залежності від зміни навколишнього середовища, зокрема клімату, оцінки ступеня їхньої стійкості та екосистемних послуг, а також розробки менеджмент-планів щодо збереження природного біорізноманіття.

\section{Список посилань}

Abduloieva O.S. 2002. Ukrainian Phytosociological Collection. Series A, 1(18): 124-143. [Абдулоєва О.С. 2002. До синтаксономії ксерофітної трав'янистої рослинності Західного Лісостепу. Український фіточенологічний збірник. Серія А, 1(18): 124-143].

Abduloieva O.S., Didukh Ya.P. 1999. Ukrainian Phytosociological Collection. Series A, 3(14): 10-36. [Абдулоєва О.С. Дідух Я.П. 1999. Лучно-степова рослинність еродованих схилів Придністров'я (Національний природний парк "Подільські Товтри") 
в аспекті їі охорони. Украӥнський фітоиенологічний збірник. Серія А, 3(14): 10-36].

Aleksandrova V.D. 1969. Klassifikatsiya rastitelnosti. Obzor printsipov klassifikatsii $i$ klassifikatsionnykh sistem $v$ raznykh geobotanicheskikh shkolakh. Leningrad: Nauka, 275 pр. [Александрова В.Д. 1969. Классификация растительности. Обзор принциипов классификациии и классификационных систем в разных геоботанических школах. Ленинград: Наука, 275 с.].

Braun-Blanquet J. 1928 (1964). Grundzüge der Vegetationskund. In: Pflanzensoziologie. Ed. J. BraunBlanquet. Berlin: Verlag von Julius Springer, $865 \mathrm{~S}$.

Budzhak V.V., Chorney I.I., Tokariuk A.I., Kuzemko A.A. 2016. Numeric syntaxonomical analysis of the communities with participation of species from Molinia caerulea complex in the southwest of Ukraine. Hacquetia, 15(2): 63-77.

Chervona knyha Ukrainy. Roslynnyi svit. 2009. (Red Data Book of Ukraine. Plant Kingdom). Ed. Ya.P. Didukh. Kyiv: Globalconsulting, 912 pp. [Червона книга України. Рослинний світ. 2009. Ред. Я.П. Дідух. Київ: Глобалконсалтинг, 912 с.].

Didukh Ya.P., Chorney I.I., Budzhak V.V., Vashenyak Yu.A., Korzhyk V.P., Rozenblit Yu.V., Tokaryuk A.I., Mykhaylyuk T.I. 2018a. Ukrainian Botanical Journal, 75(2): 149-159. [Дідух Я.П., Чорней I.I., Буджак В.В., Вашеняк Ю.А., Коржик В.П., Розенбліт Ю.В., Токарюк А.I., Михайлюк Т.I. 2018а. Рідкісний туфогенний біотоп у басейні Дністра. Украӥнський ботанічний журнал, 75(2): 149-159]. https://doi. org/10.15407/ukrbotj75.02.149

Didukh Ya., Chorney I., Budzhak V., Vasheniak Yu., Rosenblit Yu., Tokariuk A. \& Mikhailyuk T. 2018b. Habitats $7220-$ Petrifying springs with tufa formations (Cratoneurion) in the basin of Dniester River (Ukraine). In: Vegetation survey 90 years after the publication of Braun-Blanquet's textbook-new challenges and concepts Book of Abstracts (27 $7^{\text {th }}$ Congress of the European Vegetation Survey. 23-26 May. 2018 Wroclaw, Poland). Wroclaw, 106 pp.

Didukh Ya.P. Vasheniak Yu.A. 2011. Ukranian Botanical Journal, 68(4): 491-506. [Дідух Я.П.. Вашеняк Ю.А. 2011. Синфітоіндикаційна оцінка рослинних угруповань Центральноподільського геоботанічного округу. Украӥнський ботанічний журнал, 68(4): 491-506].

Didukh Ya.P. Vasheniak Yu.A. 2012. Ukranian Botanical Journal, 69(6): 789-818. [Дідух Я.П. Вашеняк Ю.А. 2012. Степова рослинність Центрального Поділля. Украӥнський ботанічний журнал, 69(6): 789-818].

Didukh Ya.P, Vasheniak Yu. A. 2018. Vegetation of limestone outcrops in Western and Central Podilla (Ukraine). Tuexenia, 38: 1-26. https://doi.org/10.14471/2018.38.023

Didukh Ya.P., Shelyah-Sosonko Yu.R. 2003. Ukranian Botanical Journal; 60(1): 6-17. [Дідух Я.П., ШелягСосонко Ю.Р. 2003. Геоботанічне районування України та суміжних територій. Украӥнський ботанічний журнал, 60(1): 6-17].

Dubyna D.V., Dzyuba T.P., Yemelyanova S.M., Bahrikova N.O., Borysova O.V., Borsukevych L.M., Vynokurov D.S., Hapon S.V., Hapon Yu.V., Davydov D.A., Dvoretskyi T.V., Didukh Ya.P., Zhmud O.I., Kozyr M.S., Konishchuk V.V., Kuzemko A.A., Pashkevych N.A., Ryff L.E., Solomakha V.A., Felbaba-Klushyna L.M., Fitsaylo T.V., Chorna H.A., Chorney I.I., ShelyahSosonko Yu.R., Yakushenko D.M. 2019. Prodrome of the Vegetation of Ukraine. Eds D.V. Dubyna, T.P. Dzyuba. Kyiv: Naukova Dumka, 782 рр. [Дубина Д.В., Дзюба Т.П., Смельянова С.М., Багрікова Н.О., Борисова О.В., Борсукевич Л.М., Винокуров Д.С., Гапон С.В., Гапон Ю.В., Давидов Д.А., Дворецький Т.В., Дідух Я.П., Жмуд О.І., Козир М.С., Коніщук В.В., Куземко А.А., Пашкевич Н.А., Рифф Л.Е., Соломаха В.А., ФельбабаКлушина Л.М., Фіцайло Т.В., Чорна Г.А., Чорней I.I., Шеляг-Сосонко Ю.Р., Якушенко Д.М. 2019. Продромус рослинності України. Відп. ред. Д.В. Дубина, Т.П. Дзюба. Київ: Наукова думка, 782 с.].

Eliáš P. 2017. Komentovaný prehl'ad rastlinných spoločenstiev: mikroregión Tribečsko. Nitra: Slovenskej pol'nohospodárskej univerzity v Nitre, $156 \mathrm{pp}$.

Fitsaylo T.V. 2007. Visnyk of the Lviv University. Series Biology, 43: 115-125. [Фіцайло Т.В. 2007. Lamio purpureae-Acerion tatarici - новий союз класу RhamnoPrunetea Rivas Goday et Carb. 1961. Вісник Львівського університету. Серія Біологічна, 43: 115-125].

Fitsaylo T.V. 2014. Naukovi zasady pryrodookhoronnoho menedzhmentu ekosystem Kanyonovoho Prydnistrov'ya: materialy pershoi mizhnarodnoi naukovo-praktychnoi konferentsii, prysvyachenoi storichchyu botanichnykh doslidzhen u rehioni. Lviv: Liha-Press, pp. 204-209. [Фіцайло Т.В. 2014. Екологічна диференціація чагарникової рослинності Подільсько-Бессарабського Придністров'я. В зб: Наукові засади природоохоронного менеджменту екосистем Каньйонового Придністров'я: матеріали першої міжнародної науково-практичної конференцї, присвяченої сторіччю ботанічних досліджень у регіоні (Заліщики, 11-12 вересня 2014 р.). Львів: Ліга-Прес, с. 204-209].

Fitsaylo T.V. 2016. Visnyk of the Lviv University. Series Biology, 71: 72-84. [Фіцайло Т.В. 2016. Чагарникова рослинність Подільсько-Бессарабського Придністров'я. Вісник Львівського університету. Серія біологічна, 71: 72-84].

Goncharenko I., Semenishchenkov Y., Tsakalos J.-L., Mucina L. 2020. Thermophilous oak forests of the steppe and forest-steppe zones of Ukraine and Western Russia. Springer. Biologia, 17 pp. http://dx.doi.org/10.2478/ s11756-019-00413-w

Grime J.P. 1974. Evidence for the existence of three primary strategies in plant and its relevance to ecological and evolutionary theory. The American Naturalist, 111(982): 1169-1194. 
Grime J.P. 1979. Plant strategies and vegetation processes. Chichester: J. Willey Publ., 222 pp.

Hennekens S.M., Schaminée J.H.J. 2001. TURBOVEG. A comprehensive data base management system for vegetation data. Journal of Vegetation Science, 12(4): 589-591. https://doi.org/10.2307/3237010

Hennekens S.M 2009. TURBOVEG for Windows. Version 2. Ed. S.M. Hennekens. Wageningen: Inst. voor Bos en Natur, 96 pp.

Hrivnák R., Slezák M., Ujházy K., Máliš F., Blanár D., Ujházyová M., Kliment J. 2019. Phytosociological approach to scree and ravine forest vegetation in Slovakia. Annals of Forest Research, 62(2): 183-200. https://doi. org/10.15287/afr.2019.1355

Korotchenko I.A. 2004. Scientific Herald of Chernivtsy University. Biology (Biological Systems), 223: 197-221. [Коротченко I.A. 2004. Степова рослинність південної частини національного природного парку "Подільські Товтри". Науковий вісник Чернівеиького університету. Біологія (Біологічні системи), 223: 197-221].

Korotchenko I.A, Didukh Ya.P. 1997. Ukrainian Phytosociological Collection. Series A. Phytosociology, 1: 20-40. [Коротченко І.А. Дідух Я.П. 1997. Степова рослинність південної частини Лівобережного Лісостепу України. II. Клас Festuco-Brometea. Український фітоценологічний збірник. Серія А. Фітосоиіологія, 1: 20-40].

Kozak M.I. 2012. Vyshcha vodna flora ta roslynnist Zakhidnoho Podillya: syntaksonomiya, antropohenna dynamika, okhorona. Ed. M.I. Kozak. Kam'yanetsPodilskyi: Medobory-2006, 268 pp. [Козак M.I. 2012. Вищза водна флора та рослинність Західного Поділля: синтаксономія, антропогенна динаміка, охорона. Від. ред. М.І. Козак. Кам'янець-Подільський: Медобори-2006, 268 с.].

Mosyakin S.L., Fedoronchuk M.M. 1999. Vascular plants of Ukraine. A nomenclatural checklist. Kyiv, 345 pp.

Mucina L., Bültmann H., Dierßen K., Theurillat J.-P., Raus T., Čarni A., Šumberová K., Willner W., Dengler J., Gavilán García R., Chytrý M., Hájek M., Di Pietro R., Iakushenko D., Pallas J., Daniëls F.J.A., Bergmeier E., Santos Guerra A., Ermakov N., Valachovič M., Schaminée J.H.J., Lysenko T., Didukh Y.P., Pignatti S., Rodwell J.S., Capelo J., Weber H.E., Solomeshch A., Dimopoulos P., Aguiar C., Hennekens S.M., Tichý L. 2016. Vegetation of Europe: hierarchical floristic classification system of vascular plant, bryophyte, lichen, and algal communities. Applied Vegetation Science, 19 (Suppl. 1): 3-264.
Onyshschenko V.A. 2009. Forests of order Fagetalia Sylvaticae in Ukraine. Ed. S.L. Mosyakin. Kyiv: Alterpress, 212 pp.

Roleček J., Tichý L., Zelený D., Chytrý M. 2009. Modified TWINSPAN classification in which the hierarchy respects cluster heterogeneity. Journal of Vegetation Science, 20: 596-602.

Solodkova T.I., Bayrova R.S., Zayets T.S., Movchan Ya.I., Sendzyk N.O., Solomakha V.A., Shelyah-Sosonko Yu.R. 1986. Ukranian Botanical Journal, 43(1): 2834. [Солодкова T.I., Байрова Р.С., Заєць Т.С., Мовчан Я.І., Сендзик Н.О., Соломаха В.А., ШелягСосонко Ю.Р. 1986. Флористична класифікація степової рослинності Буковинського Придністров'я. Украӥнський ботанічний журнал, 43(1): 28-34].

Tichý L. 2002. JUICE. Software for vegetataion classification. Journal of Vegetation Science. 13(3): 451-453. https://doi. org/10.1111/j.1654-1103.2002.tb02069.x

Yunatov A.A. 1964. Typy y soderzhanye heobotanycheskykh yssledovanyi. Vybor probnykh ploshchadey y zalozhenye ekolohycheskykh profyley. In: Polevaya heobotanyka, vol. 3. Moscow; Leningrad: Nauka, pp. 9-36. [Юнатов A.A. 1964. Tипь и содержание геоботанических исследований. Выбор пробных площуадей и заложение экологических профилей. В кн.: Полевая геоботаника, т. 3. Москва; Ленинград: Наука, с. 9-36].

Van der Maarel E. 2004. Vegetation ecology - an overview. In: Vegetation Ecology. Oxford: Blackwell Publishers, pp. 1-51.

Vasheniak Yu.A. 2013. Biolohichni systemy, 5(2): 210219. [Вашеняк Ю.А. 2013. Узлісні угруповання класу Trifolio-Geranietea sanguinei Th.Miller 1961 на Центральному Поділлі. Біологічні системи, 5(2): 210-219].

Vasheniak Yu.A. 2016. Biolohichni systemy, 8(1): 108117. [Вашеняк Ю.А. 2016. Біотопічне різноманіття трав'яних угруповань Центрального Поділля та їх созологічна оцінка. Біологічні системи, 8(1): 108-117].

Vasheniak Yu., Didukh Ya., Rozenblit Yu. 2021. Dry grasslands on sedimentary outcrops of the Dniester canyon (Ukraine). Biologia, 76: 1109-1126. http://doi. org/10.1007/s11756-021-00709-w

Рекомендує до друку М.М. Федорончук 
Дідух Я.П., Розенбліт Ю.В., Буджак В.В., Чорней І.І., Токарюк А.І. 2021. Рослинність Дністровського каньйону та оцінка її адаптивного потенціалу. Украӥнський ботанічний журнал, 78(4): 282-296. https://doi.org/10.15407/ $\underline{\text { ukrbotj78.04.282 }}$

Інститут ботаніки ім. М.Г. Холодного НАН України, вул. Терещенківська 2, Київ 01601, Україна: Я.П. Дідух, Ю.В. Розенбліт. Чернівецький національний університет ім. Ю. Федьковича, вул. Коцюбинського 2, Чернівці 58012, Україна: В.В. Буджак, I.I. Чорней, А.І. Токарюк.

Реферат. Подано синтаксономію природної рослинності Дністровського каньйону, яка представлена 20 класами, 30 порядками, 44 союзами, 71 асоціацією. Встановлено, що природну рослинність каньйону формують угруповання класів Carpino-Fagetea sylvaticae, Quercetea pubescentis, Quercetea robori-petraeae, Alno glutinosaePopuletea albae, Crataego-Prunetea, Festuco-Brometea, Trifolio-Geranietea sanguinei, Molinio-Arrhenatheretea, Sedo-Scleranthetea, Phragmito-Magnocaricetea, Bolboschoenetea maritimi, Isoëto-Nanojuncetea. Найвищою синтаксономічною різноманітністю характеризується трав'яна рослинність. Проведено кількісний розрахунок синтаксономічного різноманіття у тривимірній системі екологічних стратегій видів Раменського-Грайма (CRS). Оцінено адаптивні можливості, які впливають на потенціал можливого подальшого розвитку лісових, чагарникових та трав'яних екосистем. З'ясовано, що динаміка лісових чагарникових, трав'яних лучних і степових угруповань визначається сукцесійними ендоекогенетичними процесами. Для петрофітних угруповань зміни флуктуаційного характеру не проявляються, а сукцесійні зміни певною мірою обмежені. Значні флуктуації властиві заплавним трав'яним угрупованням, які залежать від різкої змінюваності зволоження протягом вегетаційного сезону. Водночас наголошується, що реалізація цих процесів залежить від впливу зовнішніх факторів, які є регулюючим чинником можливого розвитку синтаксонів.

Ключові слова: адаптація, Дністровський каньйон, екологічні стратегії, рослинність, синтаксономія, сукцесії 


\title{
A recent find of Ophrys insectifera (Orchidaceae) in Ukraine - will it survive another 100 years?
}

\author{
Jan ROLEČEK ${ }^{1,2 *}$ (1) \\ ${ }^{1}$ Institute of Botany of the Czech Academy of Sciences, Department of Paleoecology, 25/27 Lidická, Brno 60200, Czech Republic \\ ${ }^{2}$ Department of Botany and Zoology, Faculty of Science, Masaryk University, 2 Kotlářská, Brno 61137, Czech Republic
}

\begin{abstract}
Here I report the first find of Ophrys insectifera in Ukraine since 1920. A single individual was found at its last recorded site, Chortova Hora near Rohatyn (Ivano-Frankivsk Region). The species occurs in a steppe meadow habitat situated in the lower part of a steep northern slope. Local vegetation may be classified to a broadly circumscribed association Brachypodio pinnati-Molinietum arundinaceae from the alliance Cirsio-Brachypodion pinnati (class FestucoBrometea). I discuss possible causes of the long-term neglect of $O$. insectifera at the site, its habitat conditions and suitable conservation management. To ensure the continued occurrence of this poor competitor and other rare species, it is necessary to prevent accumulation of litter and successional changes of the grassland. Mowing, low-intensity grazing, controlled early spring burning or their combination may be suitable ways to achieve this.
\end{abstract}

Keywords: controlled burning, endangered species, habitat management, Opillia, plant distribution, succession, threats

Article history. Submitted 08 June 2021. Revised 20 August 2021. Published 30 August 2021

Citation. Roleček J. 2021. A recent find of Ophrys insectifera (Orchidaceae) in Ukraine - will it survive another 100 years? Ukrainian Botanical Journal, 78(4): 297-302. https://doi.org/10.15407/ukrbotj78.04.297

*Corresponding author (e-mail: honza.rolecek@,centrum.cz)

\section{Introduction}

Ophrys insectifera L. (Orchidaceae) is the most northerly distributed Ophrys species, with the range centred in France, Germany, and Switzerland, and extending to the British Isles, Baltic region, and Fennoscandia. In the south it reaches the Iberian, Apennine and Balkan peninsulas (Meusel et al., 1965-1992). In Eastern Europe it is rare, but reaches up to the South Urals (Galeyeva, 2006). Across its distribution range it favours calcareous habitats of various kinds, mainly nutrient poor semi-dry and mesic grasslands, thermophilous scrub, and open and semi-open woodlands, often dominated by pine. It may tolerate deeper shade in calcicolous beech woodlands (Stroh, 2015), and towards the western, northern, and eastern periphery of its distribution range it increasingly occupies calcareous wetlands (Wolff, 1951; Galeyeva,
2006; Roze et al., 2011; Stroh, 2015). While it is classified as Least Concern in the IUCN Red List (Rankou, 2011), it has retreated in many parts of its distribution range and is evaluated, e.g., as Critically Endangered in Bulgaria (Petrova, Vladimirov, 2009) and Denmark (Wind, 2019), Endangered in the Czech Republic (Grulich, Chobot, 2017) and Finland (Hyvärinen et al., 2019), Vulnerable in Poland (Kaźmierczakowa et al., 2016), Germany (Metzing et al., 2018), and Switzerland (Bornand et al., 2016), Declining in Russia (Bardunov, Novikov, 2008), and Rare in Romania (Oltean et al., 1994).

In Ukraine the species has always been very rare and a single documented record comes from Chortova Hora near Rohatyn, Ivano-Frankivsk Region (Kagalo, 2009). The species was found there in May 1920 by a Polish botanist $\mathrm{S}$. Wierdak and the corresponding specimens are deposited in the Herbarium of the Ivan Franko

(C) 2021 J. Roleček. Published by the M.G. Kholodny Institute of Botany, NAS of Ukraine. This is an open access article under the terms of the Creative Commons Attribution License (http://creativecommons.org/licenses/by/4.0/), which permits use, distribution, and reproduction in any medium, provided the original work is properly cited 
National University of Lviv (Dmytrash-Vatseba, 2018; Shumska, Dmytrash-Vatseba, 2018) and the Herbarium of the W. Szafer Institute of Botany, Polish Academy of Sciences in Krakow (B. Paszko, in litt.). The occurrence was never confirmed and the species was considered probably extinct there (Dmytrash-Vatseba, 2018). Other records in Ukraine are even older and are based only on literature data. They all come from the western part of the country, including the Eastern Carpathians (Bukovynian Carpathians, Gorgany), Northern Podillia, Opillia, and Roztochia (Kagalo, 2009; Chorney et al., 2010). Thus, the species has not been recorded in the territory of Ukraine for a century and is included in the Red Data Book of Ukraine with the highest category of threat, as Disappearing (Kagalo, 2009).

Here we report a recent find of $O$. insectifera in Ukraine, describe its habitat conditions, discuss possible causes of its long-term neglect, and propose suitable conservation management.

\section{Study area}

Chortova Hora (333 m a.s.1.) is a famous hill and a natural site near the town of Rohatyn in the western part of Ukraine (Ivano-Frankivsk Region). It is an inselberg, rising above the plateau between the valleys of the Hnyla Lypa and Studenyi Potik rivers. Its bedrock is formed of calcareous marls to clayey limestones of the Cretaceous age, overlain by Neogene gypsum (Gerasimov et al., 2004). The site is protected since 1936 (Haydukevych, 2016), in the present form since 1975 as a Botanical Nature Monument of national importance with the area of 13 ha (Zamoroka et al., 2018).

The hill is a part of the physiographic region of Rohatyn Opillia, which belongs to a broader region of the Volyno-Podolian Upland. The surrounding landscape is hilly, with elevations between 250 and $430 \mathrm{~m}$ a.s.l. Mesophilous forests dominated by Quercus robur, Carpinus betulus, and Fagus sylvatica prevail in nearnatural vegetation. Species-rich steppe grasslands and calcareous fens are scattered throughout the region, containing many habitat specialists and rare species, indicating a long history of open landscape.

\section{Methods}

Taxonomic concepts and nomenclature of vascular plant taxa mainly follow Euro +Med PlantBase (2006onward). Syntaxonomic nomenclature follows Mucina et al. (2016) down to the alliance level and Willner et al. (2019) at the association level.

\section{Results}

Recent occurrence of Ophrys insectifera at Chortova Hora was recorded on 3 June 2019. A single individual was noticed in the steppe meadow situated in the lower part of a steep northern slope. Documentary photos of the plant were taken (Fig. 1) and geographical coordinates were recorded $\left(49^{\circ} 24^{\prime} 11.0^{\prime \prime} \mathrm{N}, 24^{\circ} 39^{\prime} 53.8^{\prime \prime} \mathrm{E}\right)$. The site has not been thoroughly searched due to limited time, so the occurrence of more individuals cannot be ruled out.

The accompanying species included Brachypodium pinnatum, Briza media, Cirsium pannonicum, Filipendula vulgaris, Galium boreale, Gymnadenia conopsea, Helictochloa hookeri subsp. schelliana, Hypochaeris maculata, Lembotropis nigricans (Cytisus nigricans), Peucedanum cervaria (Cervaria rivini), Polygala comosa, Ranunculus breyninus, and Thesium linophyllon. The herb layer cover was relatively low as compared to the surrounding stands (about 65\%). There was some litter accumulated on the ground as the vegetation was not burned that year.

\section{Discussion}

\section{New find}

The find reported here confirms the occurrence of Ophrys insectifera at Chortova Hora and whole Ukraine after 99 years. I assume the species was overlooked and was continuously present at the site, despite frequent visits by botanists. The small population size and perhaps also irregularity in flowering (Dorland, Willems, 2002) may have contributed to the neglect. Moreover, suitability of available habitats at Chortova Hora for the species is questionable. While steppe grasslands on the sun-exposed slopes may be too dry, grasslands on a shady slope may be too tall and closed, leaving little space for this lowgrowing species. Stands of the kind where Ophrys was found, with lower cover of herbs and grasses and high abundance of competitively inferior mesophilous species (e.g. Gymnadenia conopsea and Ranunculus breyninus), are less abundant on the shady slope and should preferably be explored when searching for the species.

\section{Conservation management}

The vegetation on the northern slope of Chortova Hora may be classified to a broadly circumscribed association Brachypodio pinnati-Molinietum arundinaceae from the alliance Cirsio-Brachypodion pinnati (class Festuco- 

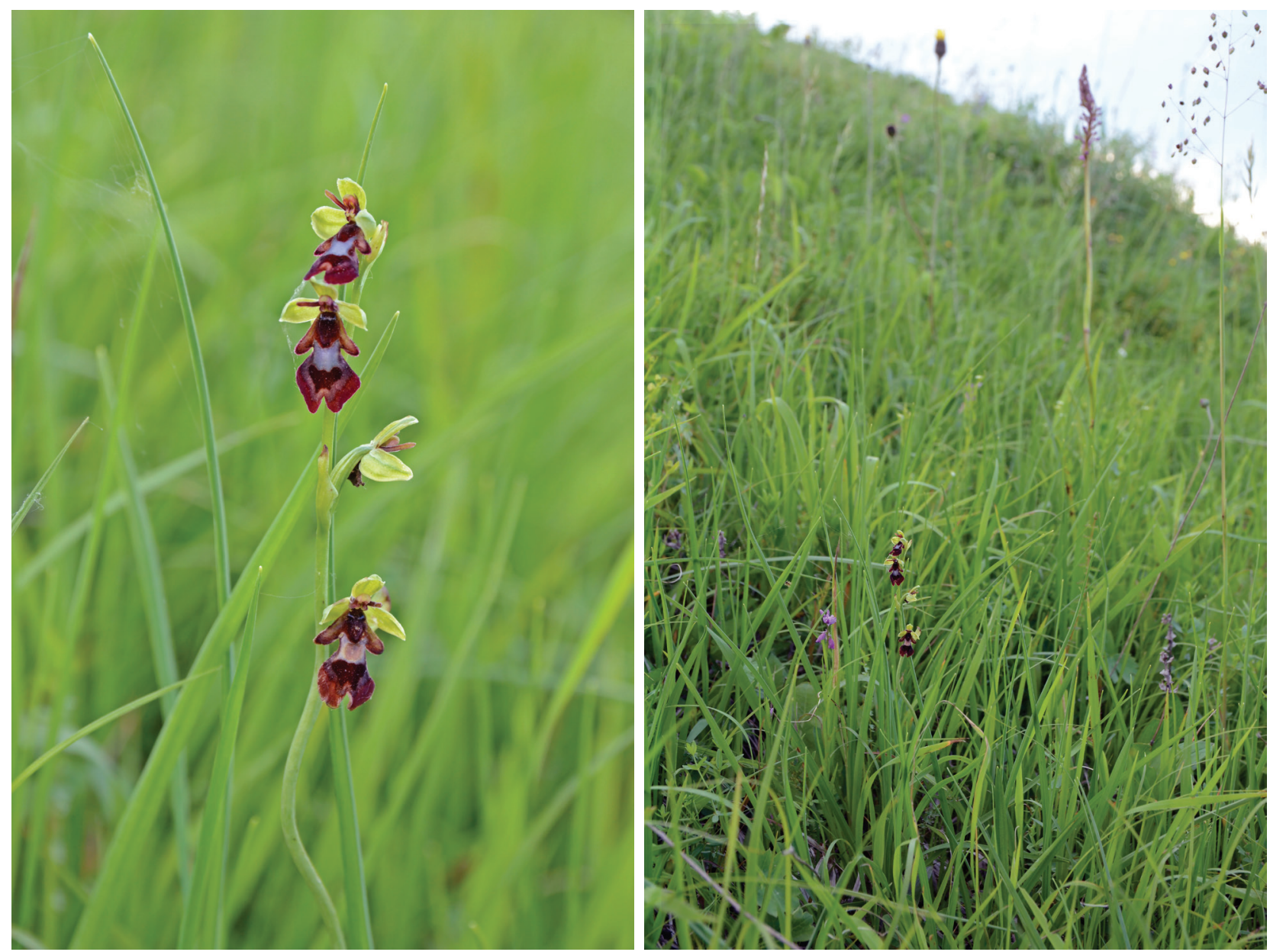

Fig. 1. Ophrys insectifera in steppe meadow at Chortova Hora near Rohatyn

Brometea) (Roleček et al., 2019; Willner et al., 2019). This type of dry-mesic steppe meadows is very species rich, but at the same highly productive, and thus preservation of its plant diversity requires regular biomass removal, which was historically done mainly through mowing (Roleček et al., 2014). Also, the grasslands at Chortova Hora used to be utilized for haymaking, probably combined with grazing (Haydukevych, 2016; Zamoroka et al., 2018). Recently, however, none of these management forms was applied and biomass removal was done through off-season grassland burning. During my last visits in 2019 and 2021, I have not observed any traces of burning, while litter accumulation was apparent.

To facilitate survival of $O$. insectifera and other poor competitors, it is necessary to continue some form of conservation management. If mowing and low-intensity grazing are not available, continuation of the previously practiced early spring burning may be an ecologically convenient and economically affordable option. According to recent studies, burning may prevent or slow down successional changes of forest-steppe habitats following their abandonment (Dmytrash-Vatseba, Shumska, 2020; Ónodi et al., 2021). This is in agreement with our observations from a number of steppe grasslands in Western Ukraine and Romania (Roleček et al., 2019, 2021). Although detrimental effects of burning have been reported too (Ruprecht et al., 2013; Polchaninova et al., 2019), I assume that positive effects prevail, as litter accumulation and woody species encroachment may be very harmful for the diversity of steppe species (Ruprecht et al., 2010; Kelemen et al., 2013; Boch et al., 2019). Despite recent efforts to eradicate spring burning of the grasslands in Ukraine (Burkovskyy et al., 2013; https://necu.org.ua/zupynymo-vogon-razom) controlled and properly timed burning of abandoned steppes may be viewed as an effective habitat management tool. 


\section{Acknowledgements}

I dedicate this paper to the memory of Nadiya V. Shumska, a recently deceased expert in the Western Ukrainian steppes, who introduced me to the flora of Chortova Hora. I would like to thank Barbora Rolečková, Prokop Roleček and Alena Rolečková for the pleasant company during the field trip in 2019, Beata Paszko for providing information from the Herbarium of the W. Szafer Institute of Botany in Krakow, and Anna A. Kuzemko for useful comments on the manuscript.

This paper was prepared with the support of the Czech Science Foundation (Project 20-09895S) and the Czech Academy of Sciences (long-term developmental project RVO 67985939).

\section{References}

Bardunov L.V., Novikov V.S. 2008. Krasnaya kniga Rossiyskoy federatsii (rasteniya $i$ griby). Moscow: Ministerstvo prirodnykh resursov i ekologii RF i Rosprirodnadzor, 856 pp. [Бардунов Л.В., Новиков, В.С. 2008. Красная книга Российской федерации (растения и грибы). Москва: Министерство природных ресурсов и экологии РФ и Росприроднадзор, 856 с.]

Boch S., Bedolla A., Ecker K.T., Ginzler C., Graf U., Küchler H., Küchler M., Nobis M.P., Holderegger R., Bergamini A. 2019. Threatened and specialist species suffer from increased wood cover and productivity in Swiss steppes. Flora, 258: 151444 (9 pp.). https://doi.org/10.1016/j. flora.2019.151444

Bornand C., Gygax A., Juillerat P., Jutzi M., Möhl A., Rometsch S., Sager L., Santiago H., Eggenberg S. 2016. Rote Liste Gefässpflanzen. Gefährdete Arten der Schweiz. Bern: Bundesamt für Umwelt, 178 pp.

Burkovskyy O.P., Vasylyuk O.V., Yena A.V., Kuzemko A.A., Movchan Y.I., Moysiyenko I.I., Sirenko I.P. 2013. Ostanni stepy Ukrainy: buty chy ne buty. Kyiv: Geoprynt, 38 pp. [Бурковський О.П., Василюк О.В., Єна А.В., Куземко А.А., Мовчан Я.І., Мойсієнко I.І., Сіренко І.П. 2013. Останні степи України: бути чи не бути. Київ: Геопринт, 38 с.]

Chorney I.I., Budzhak V.V., Tokaryuk A.I. 2010. Storinkamy Chervonoyi knyhy Ukrayiny (roslynnyy svit). Chernivetska oblast. Chernivtsi: DrukArt, 448 pp. [Чорней I.I., Буджак В.В., Токарюк А.I. 2010. Сторінками Червоної книги України (рослинний світ). Чернівецька область. Чернівці: ДрукАрт, 448 с.]

Dorland E., Willems J.H. 2002. Light climate and plant performance of Ophrys insectifera; a four-year field experiment in The Netherlands 1998-2001. In: Kindlmann P., Williams J., Whigham D.F. (eds.). Trends and fluctuations and underlying mechanisms in terrestrial orchid populations.. Leiden: Backhyus Publishers, pp. 225-238.
Dmytrash-Vatseba I.I. 2018. Rare species of vascular plants in Southern Opillya: population state, threats and conservation perspectives: Cand. Sci. Diss. (thesis for Ph.D. in Biology). Kyiv, M.G. Kholodny Institute of Botany NAS of Ukraine, 307 pp. (manuscript). [Дмитраш-Вацеба I.I. 2018. Раритетні види рослин Південного Опілля: стан популяцій, загрози і перспективи збереження: дис. ... канд. біол. наук (доктора філософії): спец. 03.00.05 "Ботаніка". Київ, Інститут ботаніки ім. М.Г. Холодного, 370 с. (рукопис)]

Dmytrash-Vatseba I.I., Shumska N.V. 2020. Dynamics of plant cover of meadow steppes after the cessation of traditional management in Opillia. Biosystems Diversity, 28: 224-229. https://doi.org/10.15421/012029

Euro + Med PlantBase - the information resource for EuroMediterranean plant diversity. 2006-onward. Available at: http://ww2.bgbm.org/EuroPlusMed (Accessed 25 May 2021).

Galeyeva A.Kh. 2006. Vestnik Orenburgskogo gosudarstvennogo universiteta, 2006/4: 19-22. [Галеева А.Х. 2006. Редкие виды семейства орхидных в Красной книге Республики Башкортостан и критерии их отбора. Вестник Оренбургского государственного университета, 2006/4: 19-22.]

Gerasimov L.S., Chaliy S.V., Gerasimova I.I. 2004. Geological map and map of mineral resources of pre-Quaternary units. Volyno-Podilska Series. M-35-XIX (Lviv). Kyiv: Ukrainian State Geological Research Institute, 16 pp.

Grulich V., Chobot K. (eds.). 2017. Červený seznam ohrožených druhů České republiky. Cévnaté rostliny. Príroda, 35: 1-178.

Haydukevych O. 2016. Metropolitan Andrei Sheptytskyi environmental representative of Halychyna. Skhid, 141(1): 35-39. [Гайдукевич О. 2016. Митрополит Андрей Шептицький - природоохороний діяч Галичини. Сxid, 141(1): 35-39.]

Hyvärinen E., Juslén A., Kemppainen E., Uddström A., Liukko U.-M. (eds.). 2019. The 2019 Red List of Finnish species. Helsinki: Ympäristöministeriö \& Suomen ympäristökeskus, 704 pp.

Kagalo A.A. 2009. Ophrys insectifera. In: Red Data Book of Ukraine. Plant kingdom. Ed. Ya.P. Didukh. Kyiv: Globalconsulting, p. 200. [Кагало О.О. 2009. Ophrys insectifera. В кн.: Червона книга Украӥни. Рослинний cвim. Ред. Я.П. Дідух. Київ: Глобалконсалтинг, с. 200].

Kaźmierczakowa R., Bloch-Orłowska J., Celka Z., Cwener A., Dajdok Z., Michalska-Hejduk D., Pawlikowski P., Szczęśniak E., Ziarnek K. 2016. Polska czerwona lista paprotników $i$ roślin kwiatowych. Kraków: Instytut Ochrony Przyrody Polskiej Akademii Nauk, 44 pp.

Kelemen A., Török P., Valkó O., Miglécz T., Tóthmérész B. 2013. Mechanisms shaping plant biomass and species richness: plant strategies and litter effect in alkali and loess grasslands. Journal of Vegetation Science, 24(6): 11951203. https://doi.org/10.1111/jvs.12027

Metzing D., Hofbauer N., Ludwig G., Matzke-Hajek G. (eds.). 2018. Rote Liste gefährdeter Tiere, Pflanzen und Pilze Deutschlands. Band 7: Pflanzen. Bonn-Bad Godesberg: Bundesamt für Naturschutz, 784 pp. 
Meusel H., Jäger E.J., Weinert E. 1965-1992. Vergleichende Chorologie der zentraleuropäischen Flora I-III. Jena: Gustav Fischer Verlag, 688 pp.

Mucina L., Bültmann H., Dierssen K., Theurillat J.-P., Raus T., Čarni A., Šumberová K., Willner W., Dengler J., Gavilán García R., Chytrý M., Hájek M., Di Pietro R., Iakushenko D., Pallas J., Daniëls F.J.A., Bergmeier E., Santos Guerra A., Ermakov N., Valachovič M., Schaminée J.H.J., Lysenko T., Didukh Ya.P., Pignatti S., Rodwell J.S., Capelo J., Weber H.E., Solomeshch A., Dimopoulos P., Aguiar C., Hennekens S.M., Tichý L. 2016. Vegetation of Europe: hierarchical floristic classification system of vascular plant, bryophyte, lichen, and algal communities. Applied Vegetation Science, 19 (Suppl. 1): 3-24. https://doi.org/10.1111/avsc.12257

Oltean M., Negrean G., Popescu A., Roman N., Dihoru G., Sanda V., Mihăilescu S. 1994. Studii, sinteze, documentaţii de ecologie. Lista roşie a plantelor superioare din România. București: Academia Română, Institutul de Biologie, $52 \mathrm{pp}$.

Ónodi G., Kertész M., Lengyel A., Pándi I., Somay L., Szitár K., Kröel-Dulay G.2021. The effects of woody plant encroachment and wildfire on plant species richness and composition: Temporal changes in a forest-steppe mosaic. Applied Vegetation Science, 24(1): e12546. https://doi. org/10.1111/avsc. 12546

Petrova A., Vladimirov V. 2009. Red List of Bulgarian vascular plants. Phytologia Balcanica, 15(1): 63-94.

Polchaninova N., Savchenko G., Ronkin V., Drogvalenko A., Putchkov A. 2019. Summer fire in steppe habitats: longterm effects on vegetation and autumnal assemblages of cursorial arthropods. Hacquetia, 18(2): 213-231. https:// doi.org/10.2478/hacq-2019-0006

Shumska N.V., Dmytrash-Vatseba I.I. 2018. In: Biota luchnykh stepiv Burshtynskoho Opillya. Ed. A.M. Zamoroka. IvanoFrankivsk: Symfoniya forte, pp. 45-64. [Шумська Н.В., Дмитраш-Вацеба I.I. 2018. Флора лучних степів Бурштинського Опілля. В кн.: Біота лучних степів Бурштинського Опілля. Ред. А.М. Заморока. ІваноФранківськ: Симфонія форте, с. 45-64.]

Rankou H. 2011. Ophrys insectifera. The IUCN Red List of Threatened Species 2011: e.T175957A7153465. https://dx.doi.org/10.2305/IUCN.UK.2011-2.RLTS. T175957A7153465.en (Accessed 24 May 2021).

Roleček J., Čornej I.I., Tokarjuk A.I. 2014. Understanding the extreme species richness of semi-dry grasslands in eastcentral Europe: a comparative approach. Preslia, 86(1): $5-27$.

Roleček J., Hájek M., Dřevojan P., Prokešová H., Fajmon K., Těšitel J., Daněk P., Hájková P., Jongepierová I., Novák P., Poluyanov A.V., Shumska N.V., Chorney I.I. 2019. Gradients, species richness and biogeographical links of steppe grasslands in Western Podolia (Ukraine). Phytocoenologia, 49(4): 349-367. https://doi.org/10.1127/ phyto/2019/0255
Roleček J., Dřevojan P., Iakushenko D., Hájek M. 2021. Tall herb-rich steppe in the peri-Carpathian region of Ukraine and Romania. Phytocoenologia, in press. https://doi. org/10.1127/phyto/2021/0388

Roze D., Belogrudova I., Jakobsone G., Megre D., Klavina D. 2011. Some aspects of the ecology of Ophrys insectifera. International Journal of Arts \& Sciences, 4(19): 107-120.

Ruprecht E., Enyedi M.Z., Eckstein R.L., Donath T.W. 2010. Restorative removal of plant litter and vegetation 40 years after abandonment enhances re-emergence of steppe grassland vegetation. Biological Conservation, 143(2): 449-456.

Ruprecht E., Fenesi A., Fodor E.I., Kuhn T. 2013. Prescribed burning as an alternative management in grasslands of temperate Europe: the impact on seeds. Basic and Applied Ecology, 14: 642-650.

Stroh P.A. 2015. Ophrys insectifera. In: Fly Orchid. Species Account. BSBI. Available at: https://bsbi.org/wp-content/ uploads/dlm uploads/Ophrys insectifera species account.pdf

Willner W., Roleček J., Korolyuk A., Dengler J., Chytrý M., Janišová M., Lengyel A., Aćić S., Becker T., Ćuk M., Demina O., Jandt U., Kącki Z., Kuzemko A., Kropf M., Lebedeva M., Semenishchenkov Y., Šilc U., Stančić Z., Staudinger M., Vassilev K., Yamalov S. 2019. Formalized classification of semi-dry grasslands in central and eastern Europe. Preslia, 91: 25-49. https://doi.org/10.23855/ preslia.2019.025

Wind P. 2019. Karplanter. In: Moeslund J.E. (ed.). Den danske Rødliste 2019. Aarhus: Aarhus Universitet, DCE Nationalt Center for Miljø og Energi. Available at: $\underline{\text { https:// }}$ bios.au.dk/forskningraadgivning/temasider/redlistframe (Accessed 31 May 2019).

Wolff T. 1951. Ecological investigations on the Fly Ophrys, Ophrys insectifera L. in Allindelille Fredskov, Denmark. Oikos, 3: 71-97.

Zamoroka A.M., Shumska N.V., Dmytrash-Vatseba I.I. 2018. In: Biota luchnykh stepiv Burshtynskoho Opillya. Ed. A.M. Zamoroka. Ivano-Frankivsk: Symfoniya forte, pp. 16-30. [Заморока А.М., Шумська Н.В., ДмитрашВацеба I.I. 2018. Інвентаризація лучних степів Бурштинського Опілля. В кн.: Біота лучних степів Бурштинського Опілля. Ред. А.М. Заморока. ІваноФранківськ: Симфонія форте, с. 16-30.]

Recommended for publication by I. Korotchenko 
Ролечек Я. 2021. Недавня знахідка Ophrys insectifera (Orchidaceae) в Україні - чи переживе цей вид ще одне століття? Украӥнський ботанічний журнал, 78(4): 297-302 [In English].

Інститут ботаніки, Академія Наук Чеської Республіки, вул. Лідіцька 25/27, Брно 657 20, Чеська Республіка; Університет Масарика, вул. Котляржська 37, Брно 611 37, Чеська Республіка: Я. Ролечек

Реферат. Повідомлення присвячене першій з 1920 року знахідці Ophrys insectifera в Україні. Одна особина виду була знайдена на місці його попередньої реєстрації, а саме на Чортовій горі поблизу Рогатина (ІваноФранківська обл.). Оселище виду - лучно-степова ділянка у нижній частині крутого північного схилу. Рослинність локалітету може бути віднесена до асоціації Brachypodio pinnati-Molinietum arundinaceae 3 союзу Cirsio-Brachypodion pinnati (клас Festuco-Brometea). У повідомленні обговорюються можливі причини тривалої відсутності знахідок $O$. insectifera на цій ділянці, умови ії існування та належне природоохоронне управління. Для забезпечення подальшого існування цього виду, який має слабку конкурентну здатність, а також інших рідкісних видів, необхідно запобігати накопиченню опаду й підстилки та природній сукцесії - зміни трав'яної рослинності на деревно-чагарникову. Для досягнення цього може бути запропоноване скошування травостою, низькоінтенсивний регульований випас худоби, контрольоване ранньовесняне випалювання підстилки, або ж поєднання усіх цих заходів.

Ключові слова: загрози, зникаючі види, контрольоване випалювання, Опілля, поширення рослин, природоохоронне управління, сукцесія 


\title{
The first record of Elodea nuttallii (Hydrocharitaceae) in the Lower Dnipro River
}

\author{
Anastasia O. DAVYDOVA ${ }^{1,3 *}$ (D), Kateryna S. ORLOVA-HUDIM ${ }^{2,3,4}$ (D), Ivan V. SHEVCHENKO ${ }^{2,3}$ (D), \\ Denys A. DAVYDOV ${ }^{1}$ (D), Viktoria M. DZERKAL ${ }^{3}$ \\ ${ }^{1}$ M.G. Kholodny Institute of Botany, National Academy of Sciences of Ukraine, 2 Tereschenkivska Str., Kyiv 01601, Ukraine \\ ${ }^{2}$ Kherson Hydrobiological Station of NAS of Ukraine, 87 Maria Fortus Str., Kherson 73016, Ukraine \\ ${ }^{3}$ Nyzhniodniprovskyi National Nature Park, 18 Petrenko Str., Kherson 73000, Ukraine \\ ${ }^{4}$ Kherson State University, 27 Universitetska Str., Kherson 73003, Ukraine
}

\begin{abstract}
Six localities of Elodea nuttallii were found in 2020 in the Lower Dnipro River (Kherson Region) within the territory of Nyzhniodniprovskyi National Nature Park. These are the first verified records of this alien aquatic plant (native to North America) in the Steppe Zone of Ukraine. Previously, it has been reported in Ukraine only from the Forest (Kyiv city) and Forest-Steppe (Kyiv, Poltava and Cherkasy administrative regions) zones. Geographic coordinates, depths and substrate are reported for all found localities. Geobotanical data about this species in Ukraine are summarized. It is assumed that Elodea nuttallii as a potentially invasive species in this region may occur not only in the Lower Dnipro River but also in all reservoirs on this river.
\end{abstract}

Keywords: alien species, Elodea, floristic find

Article history. Submitted 20.10.2020. Revised 24.07.2021. Published 30.08.2021

Citation. Davydova A.O., Orlova-Hudim K.S., Shevchenko I.V., Davydov D.A., Dzerkal V.M. 2021. The first record of Elodea nuttallii (Hydrocharitaceae) in the Lower Dnipro River. Ukrainian Botanical Journal, 78(4): 303-307. https:// doi.org/10.15407/ukrbotj78.04.303

*Corresponding author (e-mail: anasta3Kz@gmail.com)

Elodea nuttallii (Planch.) H.St.John (basionym Anacharis nuttallii Planch.) is a perennial submerged aquatic plant described from North America and at present distributed mostly in mid- and north-eastern USA and Canada (St. John, 1920; Simpson, 1984). It is an alien species in Europe first reported from Belgium in 1939 (Simpson, 1984). Found also in Great Britain in 1966, currently this plant is distributed in fresh or brackish waters in many other European countries, including Austria, Belarus, Bulgaria, Croatia, Czech Republic, Denmark, France, Hungary, Italy, Ireland, Germany, Luxembourg, Netherlands, Romania, Russian Federation, Serbia, Slovakia, Slovenia, Sweden, and Switzerland (Simpson, 1984; Escobar et al., 2011; Hussner, 2012; Kočić et al.,
2014; Panasenko, Shcherbakov, 2018). Outside Europe, it was reported from Japan (Kunii, 1984), Philippines and China (Wang et al., 2016).

In Ukraine, Elodea nuttallii was first reported from a bay of the Kaniv Reservoir on the Dnipro River("Kuriache Horlo" boundary) in 2004 and one year later - in a bay of the Dnipro River near Tsybli village (both locations are now in Boryspil District, Kyiv Region) by Chorna, Protopopova, Shevera, and Fedoronchuk (Chorna et al., 2006). In 2012, E. nuttallii was reported by Starovoytova (2011) in the Lower Sula River near Demyanivka village (Kremenchuk District, Poltava Region). Two recent papers of Prokopuk and Zub $(2019 ; 2020)$ provide morphological features of species of the genus Elodea

(C) 2021 A.O. Davydova, K.S. Orlova-Hudim, I.V. Shevchenko, D.A. Davydov, V.M. Dzerkal. Published by the M.G. Kholodny Institute of Botany, NAS of Ukraine. This is an open access article under the terms of the Creative Commons Attribution License (http://creativecommons.org/licenses/ by/4.0/), which permits use, distribution, and reproduction in any medium, provided the original work is properly cited 


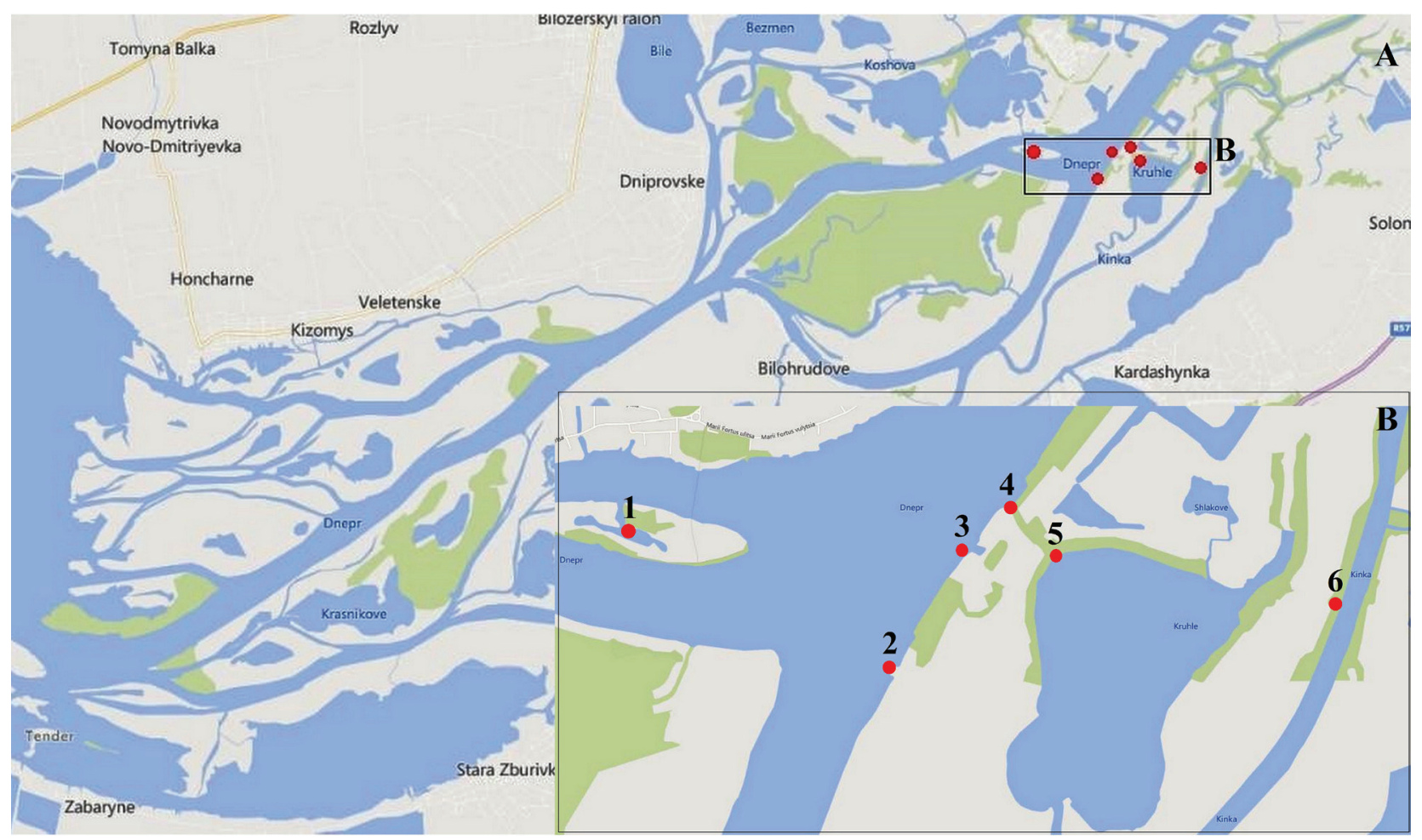

Fig. 1. Schematic map of new localities of Elodea nuttallii in the Lower Dnipro River

Table 1. Localities of Elodea nuttallii in the Lower Dnipro River

\begin{tabular}{|c|c|c|c|c|c|c|}
\hline \multirow{2}{*}{ No } & \multirow{2}{*}{ Locality } & \multicolumn{2}{|c|}{ Coordinates } & \multirow{2}{*}{$\begin{array}{c}\text { Depth, } \\
\mathrm{m}\end{array}$} & \multirow{2}{*}{ Substrate } & \multirow{2}{*}{ Date } \\
\hline & & Latitude $(\mathrm{N})$ & Longitude (E) & & & \\
\hline 1 & Lebedyne Lake & $46^{\circ} 35^{\prime} 55.3^{\prime \prime}$ & $32^{\circ} 34^{\prime} 16.3^{\prime \prime}$ & 0.5 & silted sand & 30.09 .2020 \\
\hline 2 & \multirow{2}{*}{ The Dnipro River } & $46^{\circ} 35^{\prime} 35.0^{\prime \prime}$ & $32^{\circ} 35^{\prime} 25.5^{\prime \prime}$ & $6-7$ & \multirow{2}{*}{ silted sand } & 13.07.2020, \\
\hline 3 & & $46^{\circ} 35^{\prime} 52.8^{\prime \prime}$ & $32^{\circ} 35^{\prime} 40.5^{\prime \prime}$ & $3-4$ & & 17.08 .2020 \\
\hline 4 & Strait to Krugle Lake & $46^{\circ} 35^{\prime} 58.6^{\prime \prime}$ & $32^{\circ} 35^{\prime} 54.3^{\prime \prime}$ & $1.5-2.3$ & sandy silt & $\begin{array}{c}17.08 .2020 \\
14.09 .2020\end{array}$ \\
\hline 5 & Krugle Lake & $46^{\circ} 35^{\prime} 50.0^{\prime \prime}$ & $32^{\circ} 36^{\prime} 03.8^{\prime \prime}$ & $1.8-2.5$ & sandy silt & $\begin{array}{l}17.08 .2020 \\
14.09 .2020\end{array}$ \\
\hline 6 & Strait to the Konka River & $46^{\circ} 35^{\prime} 44.1^{\prime \prime}$ & $32^{\circ} 37^{\prime} 16.8^{\prime \prime}$ & $0.7-1.0$ & sandy silt & 14.09 .2020 \\
\hline
\end{tabular}

Rich. in Ukraine and their current distribution. The authors reported 22 new sites for E. nuttallii: Babyne, Verkhnie Vyhurivske, Berizka, Sribnyi Kil, Yaremyne, Nebrezh and Martyshyv lakes, a lake in Zhukiv Ostriv Landscape Reserve, Halerna and Domania loughs, the mouth of the Vita River, the Desenka and Bobrovnia rivers (Kyiv city), a channel of the Bortnychi aeration station (Boryspil District, Kyiv Region), Kaniv Reservoir near Kyiliv village (Boryspil District, Kyiv Region), the Krasna River in Trypillia village and the Bobrytsia River in Khalepye village (Obukhiv District, Kyiv Region), the Nedra River in Berezan town (Brovary District, Kyiv Region), the mouth of the Trubizh River in Pereyaslav town (Boryspil District, Kyiv Region), the Dnipro River near Pekari and Prokhorivka villages and the
Kremenchuk Reservoir near Shelestiv Island in Kaniv Nature Reserve (Cherkasy District, Cherkasy Region) (Prokopuk, Zub, 2019; Zub, Prokopuk, 2020). Thus, all confirmed locations of Elodea nuttallii within Ukraine are located in the Forest (Kyiv city) and the Forest-Steppe (Kyiv, Poltava and Cherkasy regions) nature zones. For the Steppe Zone, only one record from the mouth of the Danube River (Dubyna et al., 2017) was reported. A recent record of E. nuttallii in Sevastopol, Crimea was published (Svirin et al., 2021).

During the investigation of aquatic vegetation of Nyzhniodniprovskyi National Nature Park in Kherson Region in 2020, Elodea nuttallii was found in six localities (Fig. 1).

Detailed data about our findings are summarized in Table 1.

Ukrainian Botanical Journal, 2021, 78(4) 


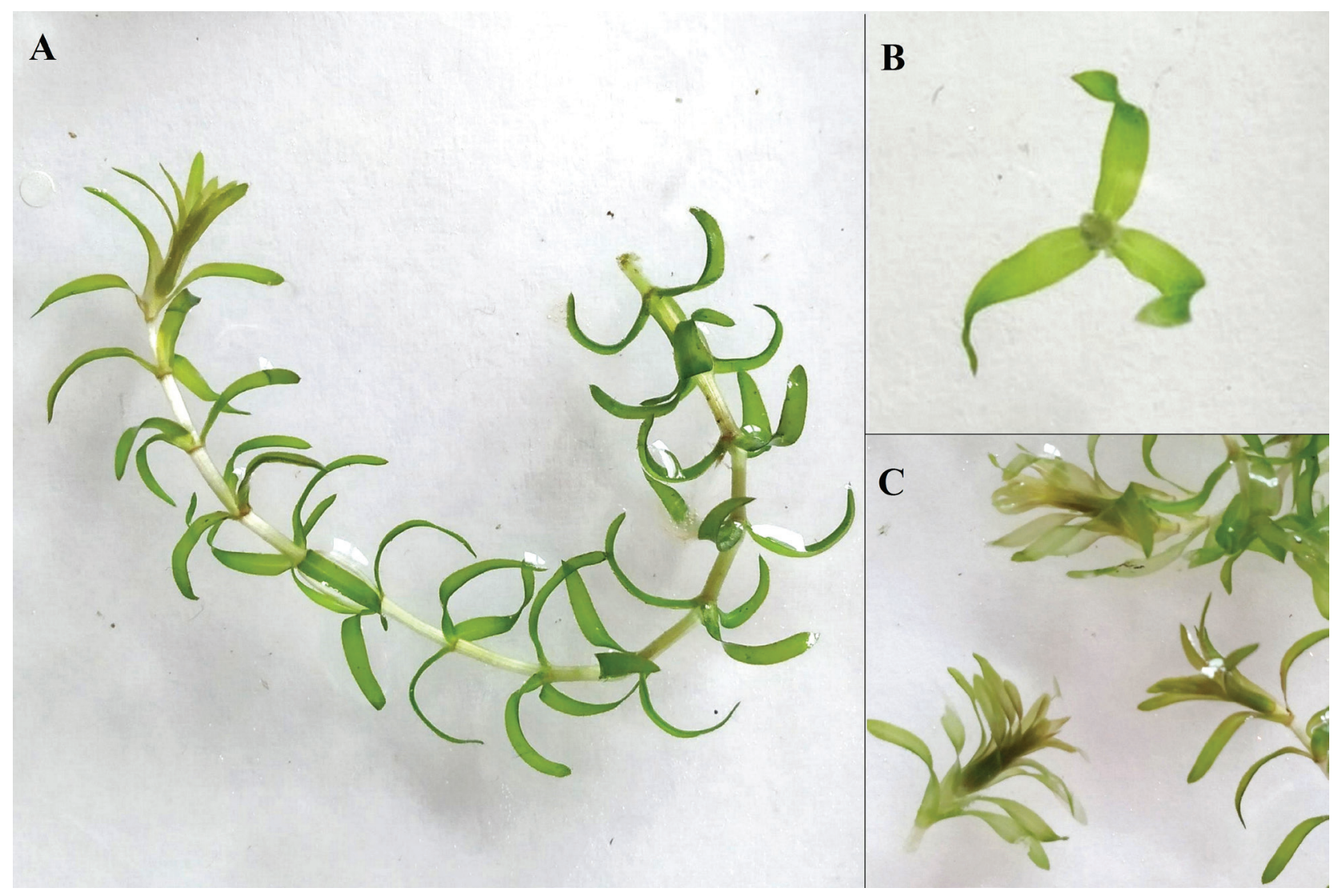

Fig. 2. Elodea nuttallii. A: a part of the plant; B: a leaf whorl; C: upper parts of stems

Our findings are not limited to the mentioned points with coordinates, since $E$. nuttallii is common between localities 1, 2 and 3, it occurs in all areas along a strait to Kruhle Lake (3) and in several areas along shores of Kruhle Lake (4) (Table 1).

Morphological characters of Elodea nuttallii are described in detail in many sources (St. John, 1920, 1965; Haynes, 2000; Chorna et al., 2006; Kočić et al., 2014). The main differences between Elodea nuttallii and Elodea canadensis Michx. are the width of a leaf measured at the point approximately $0.5 \mathrm{~mm}$ below the apex, the width/length ratio and the angle at the apex. In E. canadensis, leaves are shorter and wider, the width/ length ratio is higher and the angle at the leaf apex it is within a range $50-60^{\circ}$, in the upper part of a stem leaves usually lying along and overlapping in rows.

Leaves of the plants we observed are in whorls of three, recurved, linear to lanceolate with undulate margins (Fig. 2). The leaf width at the mid-point are $1.2-1.6 \mathrm{~mm}$ and at $0.5 \mathrm{~mm}$ below the tip $-0.57-0.62$ $\mathrm{mm}$, leaf length are $9.2-13.1 \mathrm{~mm}$ ), the width/length ratio is 0.14 , the angle at the apex is $31-34^{\circ}$. In our opinion, climatic conditions and geobotanical data for the studied localities of E. nuttallii provide additional information and may be used by other authors in further research.

Climatic conditions. According to the meteorological journal of the Kherson Hydrobiological Station of the National Academy of Sciences of Ukraine, during the last 10 years the average water temperature in the Lower Dnipro River was $14.4^{\circ} \mathrm{C}$ (the coldest in February $-1.4^{\circ} \mathrm{C}$, the warmest in July $-26.1^{\circ} \mathrm{C}$ ). During the winter period the average water temperature is $2.8^{\circ} \mathrm{C}$.

Geobotanical characteristics. In the Lower Dnipro River, Elodea nuttallii formed aquatic communities belonging to the class Potamogetonetea Klika in Klika et Novák 1941 with poor species composition (2-5 species on plots of $5 \times 5 \mathrm{~m}$ ). The species characteristic of deeper plots (6-7 $\mathrm{m}$ deep) is Potamogeton perfoliatus L., on shallowerareas-Ceratophyllum demersum L., Vallisneria spiralis L. and the underwater form of Nuphar lutea (L.) Sm. Starovoytova (2012) described communities with 
E. nuttallii and another alien aquatic species $E$. densa (Planch.) Caspari (= Egeria densa Planch.) from the Lower Sula River as the new association Egerio densaeElodeetum nutalliae Starovoytova 2012, but this name is invalid according to Art. 5 of the International Code of Phytosociological Nomenclature (Theurillat et al., 2021); besides, Elodea densa has previously never been found in the Lower Dnipro River. Dubyna with coauthors (2017) mentioned for Ukraine three associations (Polygono-Potametum natantis Soó 1957, Potametum lucentis Hueck 1931 and Potametum crispi Soó 1927) with $E$. nuttallii as an attendant species, and two syntaxa with $E$. nuttallii as a diagnostic and characteristic taxon - Elodeetum nuttallii Ciocorlan et al. 1997 and Ceratophyllo demersi-Elodeetum nuttallii Ciocorlan et al. 1997 (Dubyna et al., 2017). However, these two syntaxa described from Romania have not been listed in the Prodrome of the vegetation of Ukraine (Dubyna et al., 2019) so their presence in Ukraine needs further confirmation.

The reported localities in the territory of Nyzhniodniprovskyi National Nature Park in Kherson Region are the first verified records of Elodea nuttallii in the Steppe Zone of Ukraine. These localities were confirmed by two herbarium specimens in the Nyzhniodniprovskyi National Nature Park and three observations with photographs on iNaturalist (available at: https://www.inaturalist.org/observations/57640327; https://www.inaturalist.org/observations/57807094, and https://www.inaturalist.org/observations/57807189).

Thus, our results confirmed the distribution of the alien aquatic species Elodea nuttallii in the Lower Dnipro River (Kherson Region). It is potentially an invasive species in this region. Therefore it is necessary to explore the aquatic vegetation of all reservoirs on the Dnipro River within the Steppe Zone of Ukraine in order to obtain more data about the current distribution of this species in Ukraine.

\section{Acknowledgements}

We are grateful to Andrey Efremov (Omsk State Pedagogical University, Omsk, Russian Federation) and Dariusz Kamiński (Nicolaus Copernicus University, Torun, Poland) who confirmed our observations of Elodea nuttallii on iNaturalist and made valuable comments about these findings.

\section{References}

Chorna G.A., Protopopova V.V., Shevera M.V., Fedoronchuk M.M. 2006. Ukrainian Botanical Journal, 63(3): 328-332. [Чорна Г.А., Протопопова В.В., Шевера М.В., Федорончук М.М. 2006. Elodea nuttallii (Planch.) St. John (Hydrocharitaceae) - новий для флори України вид. Український ботанічний журнал, 63(3): 328-332].

Dubyna D.V., Dzyuba T.P., Dvoretsky T.V., Zolotareva O.K., Taran N.Yu., Mosyakin A.S., Yemelyanova S.M., Kazarinova G.O. 2017. Ukrainian Botanical Journal, 74(3): 248-262. [Дубина Д.В., Дзюба Т.П., Дворецький Т.В., Золотарьова О.К., Таран Н.Ю., Мосякін А.С., Ємельянова С.М., Казарінова Г.О. 2017. Інвазійні водні макрофіти України. Український ботанічний журнал, 74(3): 248-262]. https://doi. org/10.15407/ukrbotj74.03.248

Dubyna D.V., Dziuba T.P., Iemelianova S.M., Bagrikova N.O., Borysova O.V., Borsukevych L.M., Vynokurov D.S., Gapon S.V., Gapon Yu.V., Davydov D.A., Dvoretskyi T.V., Didukh Ya.P., Zhmud O.I., Kozyr M.S., Konishchuk V.V., Kuzemko A.A., Pashkevych N.A., Ryff L.E., Solomakha V.A., Felbaba-Klushyna L.M., Fitsailo T.V., Chorna H.A., Chorney I.I., Shelyag-Sosonko Yu.R., Iakushenko D.M. 2019. Prodrome of the Vegetation of Ukraine. Eds D.V. Dubyna, T.P. Dziuba. Kyiv: Naukova Dumka, 782 pp. [Дубина Д.В., Дзюба Т.П., Смельянова С.М., Багрікова Н.О., Борисова О.В., Борсукевич Л.М., Винокуров Д.С., Гапон С.В., Гапон Ю.В., Давидов Д.А., Дворецький Т.В., Дідух Я.П., Жмуд О.І., Козир М.С., Конішук В.В., Куземко А.А., Пашкевич Н.А., Рифф Л.Е., Соломаха В.А., ФельбабаКлушина Л.М., Фіцайло Т.В., Чорна Г.А., Чорней I.I., Шеляг-Сосонко Ю.Р., Якушенко Д.М. 2019. Продромус рослинності України. Відп. ред. Д.В. Дубина, Т.П. Дзюба. Київ: Наукова думка, 784 с.].

Escobar M.M., Voyevoda M., Fühner C., Zehnsdorf A. 2011. Potential uses of Elodea nuttallii harvested biomass. Energy, Sustainability and Society, 1(4): 1-8. https://doi. org/10.1186/2192-0567-1-4

Haynes R.R. 2000. Elodea. In: Flora of North America Editorial Committee (eds.). Flora of North America north of Mexico, vol. 22. New York; Oxford: Oxford University Press, pp. 32-34. Available at: http://www.efloras.org/ florataxon.aspx?flora id=1\&tax on id=222000059 (Accessed 20 July 2021).

Hussner A. 2012. Alien aquatic plant species in European countries. Weed Research, 52: 297-306. https://doi. org/10.1111/j.1365-3180.2012.00926.x

Kočić A., Horvatić J., Jelaska S. 2014. Distribution and morphological variations of invasive macrophytes Elodea nuttallii (Planch.) H.St.John and Elodea canadensis Michx in Croatia. Acta Botanica Croatica, 73(2): 437-446. https://doi.org/10.2478/botcro-2014-0011

Kunii H. 1984. Seasonal growth and profile structure development of Elodea nuttallii (Planch.) St. John. in pond Ojaka-Ike, Japan. Aquatic Botany, 18: 239-247. https:// doi.org/10.1016/0304-3770(84)90065-2 
Panasenko N.N., Shcherbakov A.V. 2018. Bulletin of Moscow Society of Naturalists. Biological series, 123 (6): 5859. [Панасенко Н.Н., Щербаков А.В. 2018. Elodea nuttallii (Planch.) H.St.John (Hydrocharitaceae) - новый потенциально инвазионный вид для флоры России. Бюллетень Московского общества испытателей природы. Отдел биологический, 123(6): 58-59].

Prokopuk M., Zub L. 2019. Peculiarities of species of Elodea (Hydrocharitaceae) in the aquatic ecosystems of Ukraine (East Europe). Phytologia Balcanica, 25(3): 381-386.

Simpson D.A. 1984. A short history of the introduction and spread of Elodea Michx. in the British Isles. Watsonia, 15: $1-9$.

St. John H. 1920. The genus Elodea in New England. Rhodora, 22: 17-29.

St. John H. 1965. Monograph of the genus Elodea, part 4: The species of Eastern and Central North America. Rhodora, 67: $1-35$.

Starovoytova M.Yu. 2011. Scientific reports of NULES of Ukraine, 5(27): 1-10. Available at: Available at: https:// nd.nubip.edu.ua/2011 5/11smy.pdf. [Старовойтова М.Ю. 2011. Родина Hydrocharitaceae у флорі річки Сули та іiі приток. Наукові доповіді НУБіП, 5(27): 1-10].

Starovoytova M.Yu. 2012. Bulletin of Taras Shevchenko National University. Series Introduction and conservation of plant diversity, 1(30): 45-48. [Старовойтова М.Ю.
2012. Поширення та еколого-ценотична характеристика видів Egeria densa Planchon та Elodea nutallii (Planch) у водоймах басейну р. Сули. Вісник КНУ імені Тараса Шевченка. Серія Інтродукиія та збереження рослинного різноманіття, 1(30): 45-48].

Svirin S.A., Lyamina N.V., Yena A.V. 2021. Elodea nuttallii. In: Raab-Straube E. von, Raus Th. (ed.). Euro+Med-Checklist Notulae, 13 [Notulae ad floram euro-mediterraneam pertinentes No. 42]. Willdenowia, 51: 150-151. https://doi. org/10.3372/wi.51.51112

Theurillat J.-P., Willner W., Fernández-González F., Bültmann H., Čarni A., Gigante D., Mucina L., Weber H. 2021. International Code of Phytosociological Nomenclature. $4^{\text {th }}$ ed. Applied Vegetation Science, 24(1): 1-62. https://doi.org/10.1111/avsc.12491

Wang H., Wang Q., Bowler P.A., Xiong W. 2016. Invasive aquatic plants in China. Aquatic Invasions, 11(1): 1-9. http://dx.doi.org/10.3391/ai.2016.11.1.01

Zub L.N., Prokopuk M.S. 2020. Russian Journal of Biological Invasions, 1: 8-19. [Зуб Л.Н., Прокопук М.С. 2020. Особенности инвазий макрофитов в водные экосистемы Среднего Приднепровья (Украина). Российский журнал биологических инвазий, 1: 8-19].

Recommended for publication by G.V. Boiko

Давидова А.О., Орлова-Гудім К.С., Шевченко І.В., Давидов Д.А., Дзеркаль В.М. 2021. Перші знахідки Elodea nuttallii (Hydrocharitaceae) у пониззі Дніпра. Український ботанічний журнал, 78(4): 303-307 [In English].

Інститут ботаніки ім. М.Г. Холодного НАН України, вул. Терещенківська 2, Київ 01601, Україна: А.О. Давидова, Д.А. Давидов. Херсонська гідробіологічна станція НАН України, вул. Марії Фортус 87, Херсон 73016, Україна: К.С. Орлова-Гудім, І.В. Шевченко. Національний природний парк "Нижньодніпровський", вул. Петренко 18, Херсон 73000, Україна: К.С. Орлова-Гудім, І.В. Шевченко, В.М. Дзеркаль, А.О. Давидова. Херсонський державний університет, вул. Університетська 27, Херсон 73003, Україна: К.С. Орлова-Гудім.

Реферат. У пониззі р. Дніпро (Херсонська обл.), у тому числі, на території Національного природного парку "Нижньодніпровський" у 2020 р. виявлено шість локалітетів Elodea nuttallii. В статті представлені перші достовірні знахідки цієї чужорідної водної рослини північноамериканського походження у Степовій зоні України. Раніше вид фіксували на Поліссі (Київ) та у Лісостепу (Київська, Полтавська та Черкаська області). Для виявлених локалітетів вказано географічні координати, глибину, на якій фіксували рослини, та субстрат донних відкладів. Узагальнено дані щодо еколого-ценотичних особливостей виду на території України. Відмічено, що цілком вірогідним є поширення Elodea nuttallii, як потенційно інвазійної в регіоні рослини, не лише у пониззі Дніпра, а й на всіх водосховищах Дніпровського каскаду.

Ключові слова: флористична знахідка, чужорідні види, Elodea 


\section{До 100-ліття від дня народження \\ Сигізмунда Семеновича ХАРКЕВИЧА \\ Sigizmund S. Kharkevich (on the centenary of his birth)}

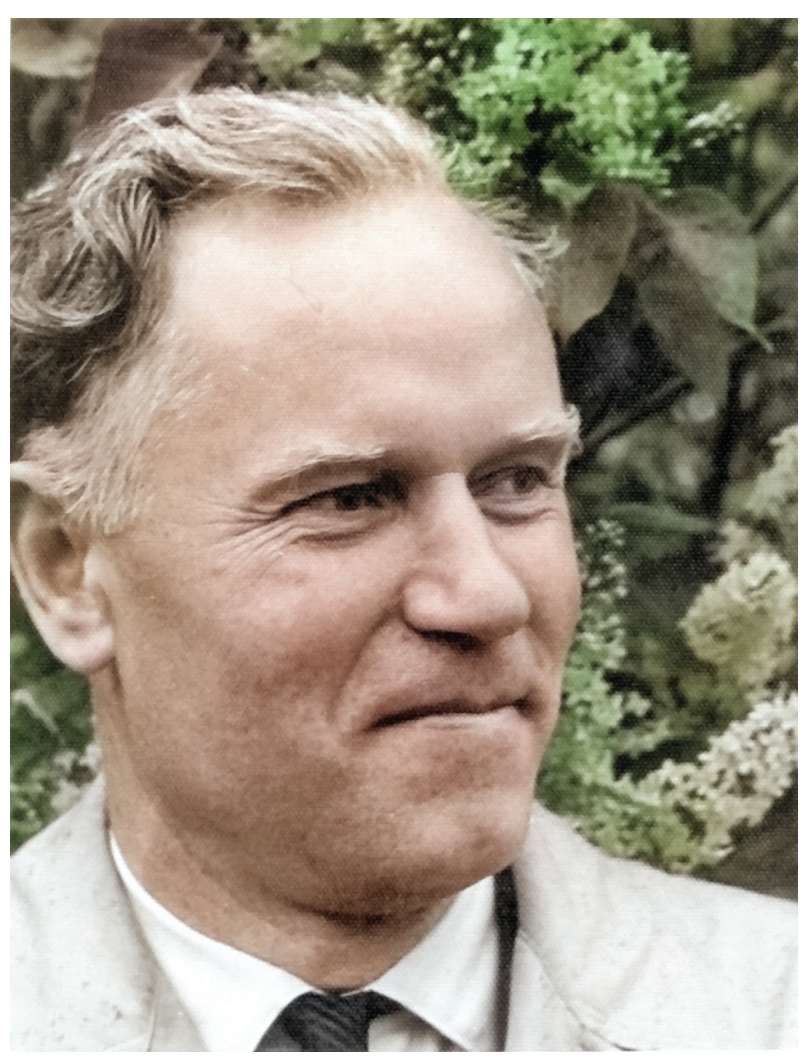

У 2021 р. виповнюється 100 років від дня народження видатного ботаніка, геоботаніка, флориста, систематика та організатора наукових досліджень, доктора біологічних наук, професора Сигізмунда Семеновича Харкевича.

Народився С.С. Харкевич 2 травня 1921 р. у с. Катеринівка Бердичівського р-ну Житомирської обл. Відмінно закінчивши середню польську школу м. Бердичева, у 1938 р. вступив до Київського державного університету на біологічний факультет. 3 тих пір справою всього його життя стала Ботаніка. Проте восени 1940 р. навчання довелося перервати через проблеми зі здоров'ям. Сигізмунд оформив річну відпустку та повернувся до рідного села, де його застала війна. Тут під час німецько-фашистської окупації він працював у колгоспі на різних сільськогосподарських роботах і вчителював у сільській школі. 3 січня 1944 р. С.С. Харкевич був призваний до лав діючої армії. Закінчив війну під Прагою, за участь у бойових діях одержав урядові нагороди.

Восени 1945 р. С.С. Харкевич поновив навчання на третьому курсі біологічного факультету Київського університету, який блискуче закінчив у 1948 р. за спеціальністю "систематика вищих рослин" і отримав рекомендацію для вступу до аспірантури. Ще будучи студентом, він узяв участь у першій науковій експедиції до Українських Карпат, яка була організована під керівництвом К.І. Косця в 1946 р. Зібраний матеріал було покладено в основу першої наукової публікації та дипломної роботи майбутнього вченого "Про флору i рослинність Закарпатської області УРСР" (1948р.).

У 1948 р. С.С. Харкевич був зарахований до аспірантури Центрального республіканського ботанічного саду АН УРСР (нині Національний ботанічний сад імені М.М. Гришка НАН України), де у відділі флори і рослинності (тепер відділ природної флори) під керівництвом професора O.I. Соколовського почав вивчати флору Кавказу. Йому доручили працювати над створенням ботанікогеографічної ділянки "Кавказ" площею близько 6 га. У подальшому саме експозиційні ділянки "Українські Карпати" (у створенні якої він також брав активну участь), а згодом і "Кавказ", стали улюбленими дослідними ділянками його київського періоду життя. В результаті численних наукових експедицій на ділянці "Кавказ" було зібрано і висаджено понад 1200 видів, що становить майже 20\% видового складу судинних рослин флори Кавказу. Під час цих експедицій було також зібрано величезний гербарій - понад 12 тис. видів (80 тис. гербарних зразків, з яких 32 тис. становили особисті збори C.С. Харкевича). Саме Сигізмунд Семенович став фундатором створення гербарію, на основі якого було започатковано Гербарій Національного ботанічного саду імені М.М. Гришка НАН України.

У 1953 р. С.С. Харкевич захистив кандидатську дисертацію за темою "Високогірна флора Північного Кавказу і можливості використання iї корисних рослин на Україні". Продовжуючи роботу на ділянці "Кавказ", він вивчав умови зростання корисних 
рослин, їхні ресурсні запаси. Паралельно досліджував угруповання декоративних ранньоквітучих рослин 3 метою створення аналогічних живописних груп у культурі.

У 1973 р. закінчився український та розпочався далекосхідний етап наукової діяльності вченого. Він був запрошений до Далекосхідного відділення АН СРСР у м. Владивосток, у якому відкривались широкі перспективи для ботанічних досліджень, i саме тут вчений очолив лабораторію "Гербарій" Біолого-грунтового інституту. Згодом упродовж багатьох років був завідувачем відділу ботаніки цієї установи. Тут С.С. Харкевич розгорнув роботу 3 поглибленого вивчення рослинного світу Далекого Сходу, організовував численні експедиції до Камчатки, Чукотки, Приморського і Хабаровського країв та інших важкодоступних районів, що дало можливість додати до флористичних списків понад сто видів рослин, що раніше не наводились для цих регіонів. За даними International Plant Names Index, IPNI (https://www.ipni.org/), C.С. Харкевич є автором чи співавтором понад тридцяти номенклатурнотаксономічних новацій (нових таксонів та номенклатурних комбінацій). Працюючи на Далекому Сході, Сигізмунд Семенович не полишав педагогічної роботи, підготувавши 14 кандидатів і докторів наук. Пізніше колеги та учні увічнили його ім'я у назвах одного нового для науки роду Kharkevichia Levichev (Liliaceae) - та понад 10 нових для науки видів рослин.

Під керівництвом С.С. Харкевича i за його безпосередньої участі було підготовлене 8-томне видання $з$ флори Радянського Далекого Сходу "Сосудистые растения Советского Дальнего Востока" (1985-1996). Багато уваги С.С. Харкевич приділяв питанню охорони генофонду далекосхідної флори, опікувався створенням заповідників та веденням Червоної книги. Так, зокрема, за його ініціативою було створено Джугджурський заповідник, розташований на узбережжі Охотського моря (Хабаровський край, РФ).

Протягом чверті століття вчений був незмінним керівником i куратором ботанічних досліджень на Далекому Сході. Важливу роль в організації наукових робіт зіграло створене С.С. Харкевичем Далекосхідне відділення наукової ради з проблеми "Біологічних основ раціонального використання, перетворення та охорони рослинного світу". 31976 до 1998 рр. він керував єдиною у Далекосхідному регіоні Спеціалізованою радою 3 присудження наукового ступеня доктора біологічних наук за спеціальністю "Ботаніка" та комісією з Комаровських читань, які щорічно проводилися у Владивостоку, керував Приморським відділенням Всеросійського ботанічного товариства, брав активну участь у роботі редколегій низки наукових часописів. 3 ім'ям Сигізмунда Харкевича пов'язаний якісно новий етап розвитку ботаніки на російському Далекому Сході.

C.C. Харкевич приділяв значну увагу збору зразків для створення Гербарію країн АзійськоТихоокеанського регіону, брав участь у виїздах на Аляску (США) та до Китаю. Був затверджений консультантом багатотомного видання "Flora of China", під час роботи над яким спілкувався 3 колегами з Місурійського ботанічного саду (СентЛуїс, США), з якими познайомився особисто під час відвідання цієї установи у 1992 p.

Завжди будучи патріотом України, він увесь час підтримував тісні контакти з українськими колегами. Працюючи на Далекому Сході, С.С. Харкевич постійно піклувався про поповнення створеного ним Гербарію ботанічного саду в Києві зразками далекосхідної флори. Усього від нього було отримано 1854 гербарних аркуша 1100 видів із 363 родів та 109 родин. Завдяки цій колекції, Гербарій Національного ботанічного саду імені М.М. Гришка НАНУ поповнився 338 новими видами зі 172 родів, що належать до 66 родин, у т. ч. Гербарій вперше отримав зразки представників родин Isoëtaceae та Penthoraceae.

За вагомі наукові здобутки С.С. Харкевич у 1993 р. отримав звання Заслуженого діяча науки РФ. Його було обрано почесним громадянином м. Владивостока, емблемою якого стала і є дотепер запропонована ним квітка рододендрона (Rhododendron mucronulatum Turcz.).

Помер Сигізмунд Семенович Харкевич 11 липня 1998 р. у Владивостоку, залишивши по собі близько 350 наукових праць і добру пам'ять колег та учнів. Його донька, Олена Сигізмундівна, виконуючи заповіт покійного, перевезла його прах до України та поховала в м. Ірпінь поруч із матір'ю. На надмогильному пам'ятнику вибиті слова, які були його девізом: "Робота - це моє життя".

У 2000 р. у м. Владивосток за підтримки Фонду Ендрю Меллона (Andrew Mellon Foundation) i за сприяння Місурійського ботанічного саду (СентЛуїс, США) вийшла друком книга "Сигизмунд Семенович Харкевич. Воспоминания современников", майже двісті сторінок якої складають світлі спогади про непересічну постать вченого, який самовіддано служив науці до останнього подиху.

B.I. МЕЛЬНИК, Н.В. ЧУВІКІНА 


\section{Соломон Павлович ВАССЕР (до 75-річчя від дня народження) Solomon P. Wasser (on the $75^{\text {th }}$ anniversary)}

У серпні 2021 р. виповнилося 75 років від дня народження і 55 років наукової діяльності всесвітньо відомого міколога й альголога, члена-кореспондента НАН України, доктора біологічних наук, професора Соломона Павловича Вассера.

Народився С.П. Вассер 26 серпня 1946 р. у м. Львів, у сім'ї інтелігентів. Його батько тривалий час працював адвокатом у Закарпатській області. Мати була професійною актрисою, а згодом викладала естетику і етику в профтехучилищі. Батьки виховали трьох дітей і зуміли прищепити дітям любов до праці, навчання, художньої літератури та мистецтва.

Після закінчення школи у м. Берегове Закарпатської обл. у 1964 р. Соломон Павлович вступив на біологічний факультет Ужгородського державного університету, обравши спеціалізацію на кафедрі систематики і морфології рослин, яку очолював відомий ботанік професор В.I. Комендар. 3 перших років навчання Соломон Павлович виявив зацікавлення до вивчення грибів-макроміцетів. На той час на кафедрі УжДУ не було відповідних фахівців, що зналися на грибах, тому В.І. Комендар звернувся за допомогою до д-ра біол. наук М.Я. Зерової - відомого українського міколога, яка на той час була завідувачкою лабораторії мікології в Інституті ботаніки АН УРСР. За керівництва Марії Яківни студент 3-го курсу С.П. Вассер під час літньої практики 1967 р. розпочав свої перші серйозні студії макроміцетів лісів Українських Карпат.

У 1969 p. Соломон Павлович вступив до аспірантури Інституту ботаніки АН УРСР за спеціальністю "ботаніка". Його офіційним науковим керівником була призначена М.Я. Зерова. Для дисертаційного дослідження були обрані базидієві шапинкові гриби степової зони України. Завдяки надзвичайній працьовитості аспіранту вдалося зібрати величезний фактичний матеріал, унаслідок обробки якого було ідентифіковано понад 600 видів макроміцетів. Дисертаційну роботу "Шляпочные грибы (пор. Boletales, Agaricales и Russulales) степной зоны Украины" успішно було захищено в 1973 р. Оскільки Соломон Павлович працював паралельно із I.M. Солдатовою, яка вивчала трутові гриби Степу України, то в 1977 р. за матеріалами досліджень вони разом опублікували монографію "Высшие базидиомицеты степной зоны Украины".

Зазначимо, що в другій половині $70-x$ років минулого століття відділ мікології Інституту ботаніки, де після закінчення аспірантури продовжив працювати Соломон Павлович, приступив до реалізації великого багатотомного проекту "Флора грибів України", задуманого ще в 50-х роках тодішнім завідувачем відділу професором С.Ф. Морочковським. Під керівництвом I.O. Дудки, на той час завідувачки відділу, С.П. Вассер взяв активну участь в обговоренні й розробці тип-листа "Флори". Для одного з перших іï томів він обрав велику й цікаву родину Agaricaceae відділу Basidiomycota. 31973 р. вчений здійснює низку експедицій до різних ботаніко-географічних районів України, а наприкінці 70-х років разом зі співробітниками відділу мікології А.С. Бухало та I.O. Дудкою проводить мікологічне обстеження ряду регіонів Сибіру, Алтаю і Далекого Сходу колишньої Російської РФСР. У цей же час дослідник опрацьовує типові зразки видів цієї родини, отримані за обміном 3 найвідоміших мікологічних гербаріїв Європи та США. Таким чином, С.П. Вассер здійснює плавний перехід до підготовки докторської дисертації. У 1980 р. він одним 3 перших (у цей час виходять ще три томи, написані іншим співробітниками відділу мікології) публікує випуск "Флоры грибов Украины", присвячений родині Agaricaceae. У монографії наведено понад 250 таксонів видового та внутрішньовидового рангів, 3 них 43 - нові для України, 9 - нові для науки, також запропоновано 20 нових номенклатурних комбінацій. Ця книга засвідчила появу в Україні агариколога світового рівня. У 1982 р. Соломон Павлович успішно захищає докторську дисертацію "Агариковые грибы (Agaricaceae (Fr.) Cohn.) Советского Союза". Пізніше основні іiі положення він викладає у монографії "Агариковые грибы СССР" (1985). У 1988-1994 pp. С.П. Вассер працює (за сумісництвом) на посаді Ukrainian Botanical Journal, 2021, 78(4) 


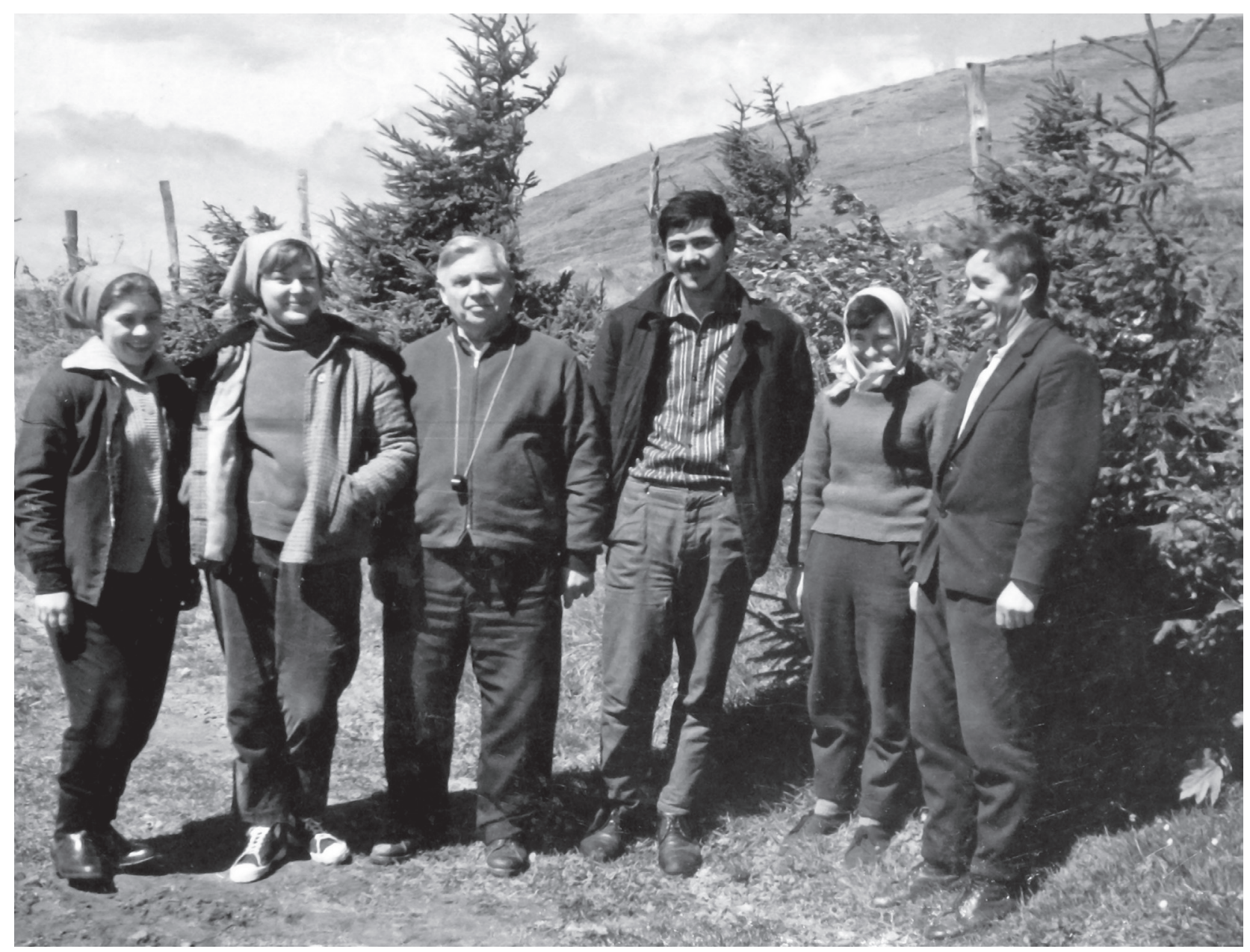

Початок наукового шляху: Р.Я. Зубець (Арап), А.М. Олешко, академік Д.К. Зеров, С.П. Вассер та місцеві природознавці під час експедиції до Українських Карпат (1967р.)

професора кафедри біології Київського медичного інституту, читає курси загальної біології, основи медичної генетики, керує науковими дослідженнями. У цей час публікує монографії та довідкові видання. У 1988 р. його обирають членом-кореспондентом АН УРСР.

За внесок у розвиток агарикології С.П. Вассер у 1991 p. був нагороджений премією Фонду Олександра та Хелен Сміт (США). Зазначимо, що Соломон Павлович продовжує вивчати й інші групи макроміцетів. Так, у 1992 р. він видає ще один випуск "Флори грибів України", присвячений мухоморовим грибам.

Крім основного мікофлористико-таксономічного напряму досліджень, у 70-90-ті роки минулого століття С.П. Вассер став головним фундатором надзвичайно важливої в Україні галузі знань, пов'язаної з промисловим культивуванням їстівних грибів. Під його керівництвом уперше в Україні були проведені дослідження, спрямовані на вдосконалення технології промислового вирощування печериці двоспорової, вперше в СРСР вдалося відібрати три високоврожайні штами Agaricus bisporus та отримати на них авторські свідоцтва. Великий внесок був зроблений у розробку технології екстенсивного культивування нового для грибівництва України виду їстівного гриба - гливи звичайної. Ця технологія була апробована і впроваджена у лісгоспах ряду областей України - Волинської, Київської, Львівської, Рівненської та Тернопільської. Без сумніву, визнання в Україні гливи як промислової культури відбулося саме завдяки науковій та організаційній діяльності групи, яку очолював Соломон Павлович. За цикл праць із промислового культивування їстівних грибів він разом із колегами у 1981 р. отримав Премію імені М.Г. Холодного АН УРСР. 


\section{121010}

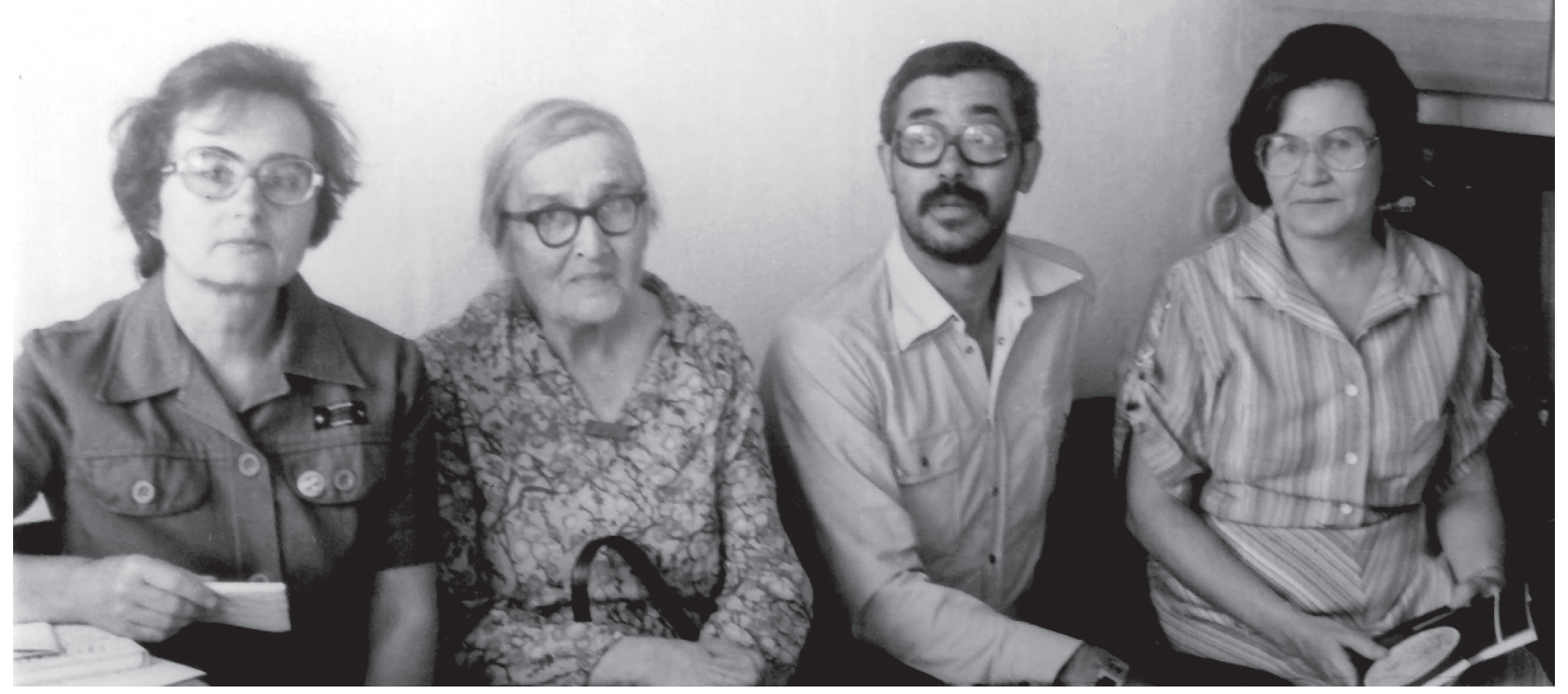

С.П. Вассер разом із І.О. Дудкою (перша зліва) в гостях у засновниці лабораторії спорових рослин Біолого-грунтознавчого інституту Далекосхідного відділення АН СРСР Л.Н. Васильєвої (друга зліва) та завідувачки цієї лабораторії 3.М. Азбукіної

Зазначимо, що С.П. Вассер $\epsilon$ засновником нового напряму в мікології - фундаментального дослідження лікарських грибів як продуцентів фармакологічно цінних речовин. Ним у 2000 р. було започатковано "International Journal of Medicinal Mushrooms", який публікує статті 3 широкого кола проблем, присвячених лікарським грибам, зокрема їхньому культивуванню, синтезу біологічно активних речовин, механізмам впливу на організм людини тощо. За ініціативи Соломона Павловича в 2001 р. у Києві відбулася I Міжнародна конференція "Perspectives of medicinal mushrooms in health care and nutrition in the $21^{\text {st }}$ century". Він був організатором i активним учасником низки міжнародних форумів, присвячених цьому напряму досліджень.

С.П. Вассер стояв біля витоків перших в Україні досліджень забруднення грибів та спорових рослин радіоактивними речовинами, що сталося внаслідок аварії на ЧАЕС у 1986 р. Він підготував кандидатку біологічних наук Г.А. Гродзинську, яка нині $\epsilon$ висококваліфікованим фахівцем 3 цієї проблеми не лише в Україні, а й поза іiі межами. Разом із колегами Соломон Павлович опублікував низку статей та кілька монографій, в яких проаналізовано результати багаторічних досліджень біоакумуляції грибами радіонуклідів чорнобильського походження: "Накопичення радіонуклідів споровими рослинами і вищими грибами України" (1995), "Макромицеты: лекарственные свойства и биологические особенности" (2012), "Аккумулятивная активность макромицетов в условиях радионуклидного загрязнения территории Украины" (2013) та ін.

Слід відмітити і вагомий внесок С.П. Вассера у справу охорони рідкісних та зникаючих видів грибів. Саме він як провідний фахівець з вивчення макроміцетів в Україні розробив підходи до відбору видів грибів для включення їх до "Червоної книги України" та запропонував список із 30 видів, що вперше увійшли до цього державного документа (друге видання, 1996 р.). При цьому він був автором десяти нарисів про види макроміцетів, що увійшли до цього видання. Попередній доробок С.П. Вассера був використаний і під час підготовки наступного, третього видання "Червоної книги України" (2009), де він також є співавтором низки статей.

Ukrainian Botanical Journal, 2021, 78(4) 


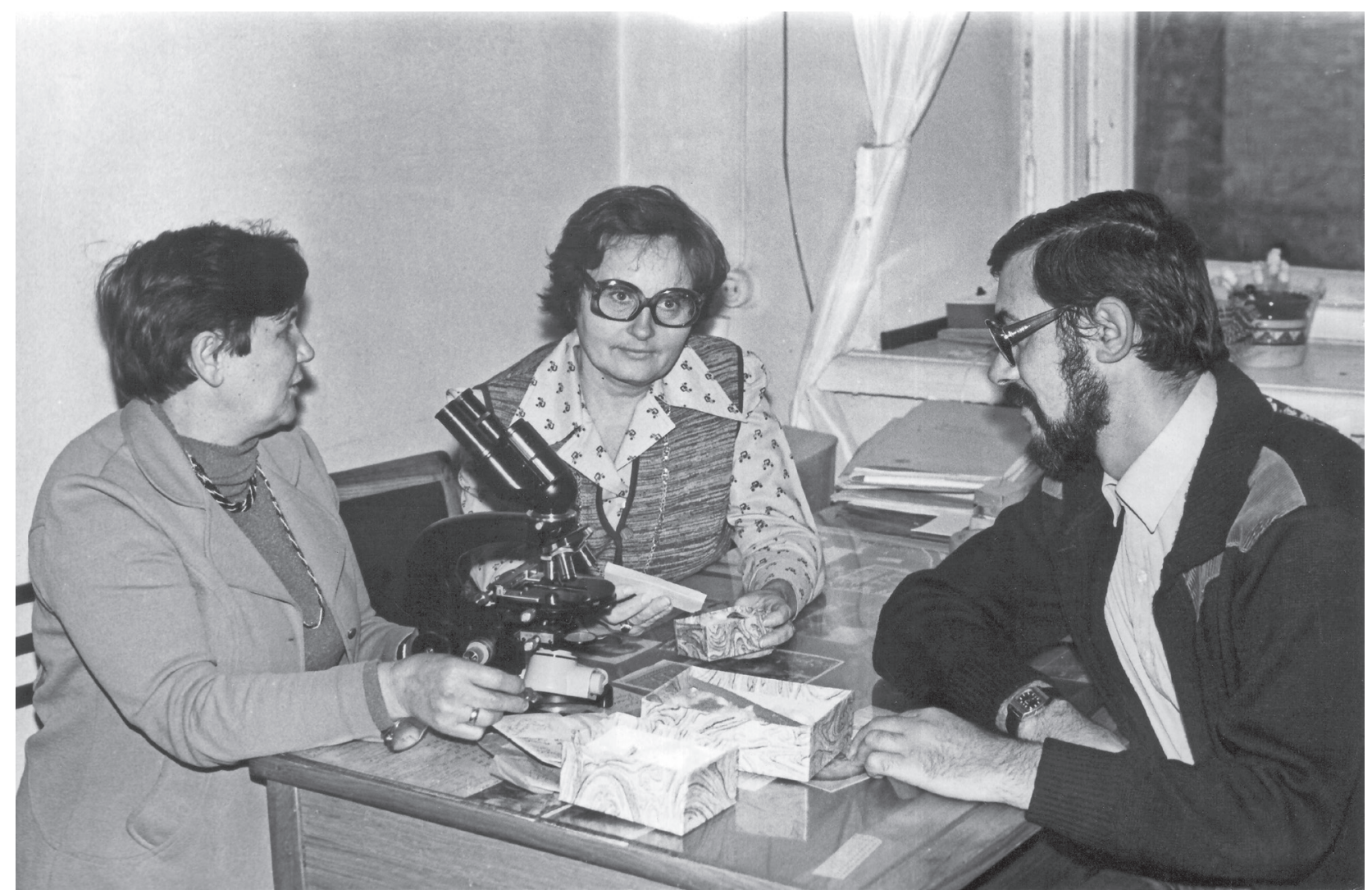

Розробники "Флоры грибов Украины" М.Ф. Сміцька, І.О. Дудка та С.П. Вассер (друга половина 1970-х років)

Ми не можемо не згадати про дуже важливий період у науковому житті Соломона Павловича, пов'язаний зовсім з іншою наукою - альгологією. У 1985 р. дирекція Інституту ботаніки запропонувала йому очолити відповідний відділ, завідувачем якого він був упродовж 17 років. Однак про ці часи у житті вченого та його досягнення розкажуть колеги-альгологи. Тому ми лише відзначимо, що за показниками науковоорганізаційної роботи цей підрозділ інституту завжди був у трійці найефективніших відділів установи.

Важливим у житті Соломона Павловича став період, коли в 1994 р. його запросили на роботу до Інституту еволюції Університету м. Хайфа (Ізраїль). Надзвичайно високий фаховий рівень та великі організаційні здібності науковця дозволили йому створити тут великий колектив мікологів-однодумців із представників різних країн світу. Він заснував Міжнародний центр біорізноманіття та біотехнології спорових рослин і грибів та лабораторію з вивчення лікарських властивостей макроміцетів. Це дозволило здійснити різносторонні дослідження грибів і лишайників Ізраїлю, вперше провести вивчення мікроміцетів Мертвого моря (виявлено біля 70 видів грибів та грибоподібних організмів), опублікувати сотні статей та монографій, присвячених грибам різних таксономічних груп - агарикальним, борошнисторосяним, іржастим, сажковим тощо. Цей період був "врожайним" на патенти. Наведемо лише деякі з них: "Substrate and method for growing shiitake mushrooms [Lentinus edodes (Berk.) Singer] and new shiitake strain" (2006), "Mushroom extracts having anticancer activity" (2007), "Extracts of Cyathus striatus mushrooms, pharmaceutical compositions comprising them and and a new Cyathus striatus strain" (2013), "Extracts of mushrooms, pharmaceutical compositions comprising them and a new strain" (2014) та ін. Зауважимо, що значні зусилля Соломона Павловича були зосереджені й на вивченні альгофлори. Вони також завершилися капітальними науковими працями. Без сумніву, завдяки діяльності С.П. Вассера у науковій історії Ізраїлю розпочався новий, ще не бачений етап 3 дослідження мікобіоти цієї країни. 


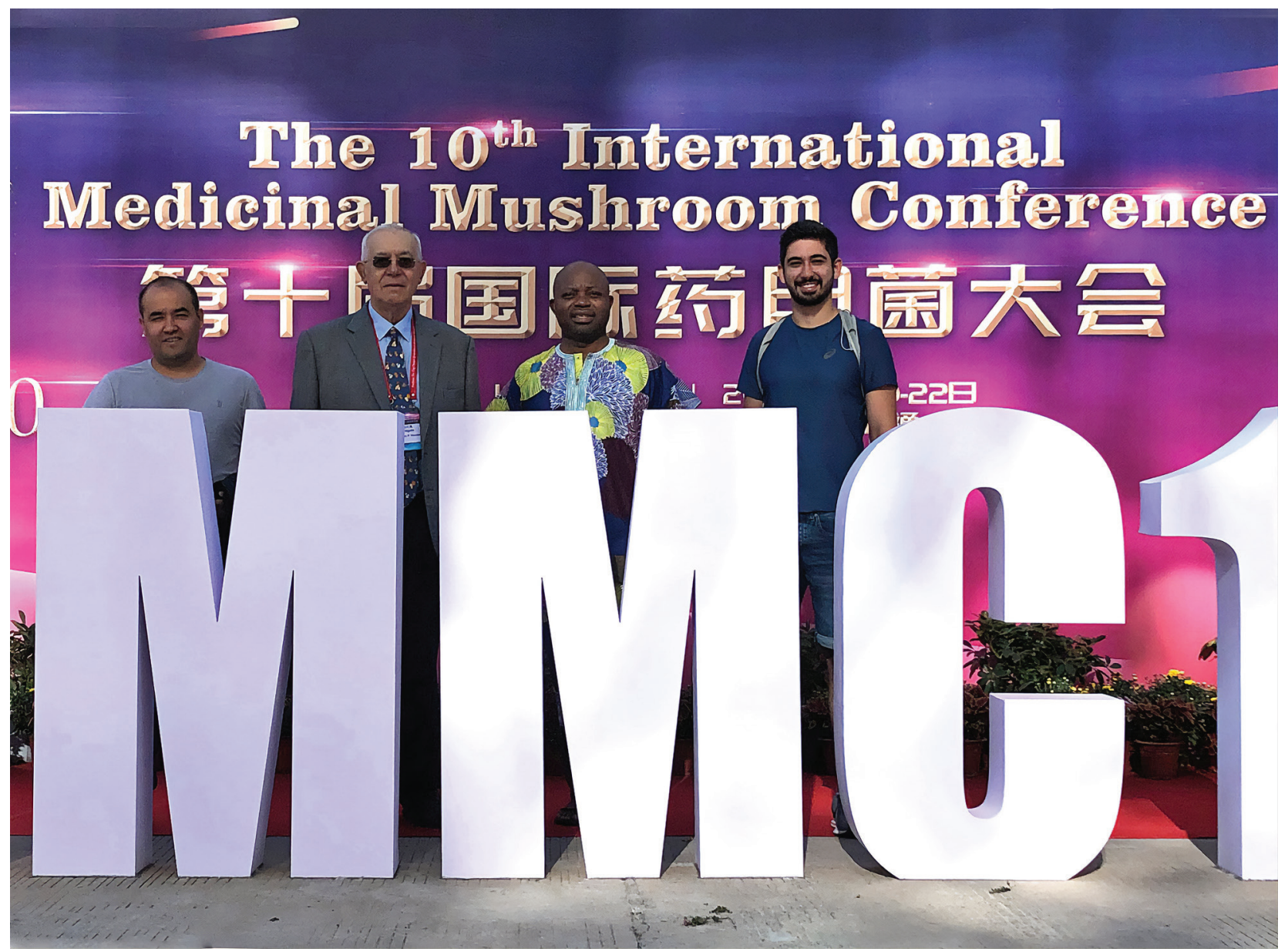

Соломон Павлович Вассер разом з іноземними колегами під час проведення 10-ї Міжнародної конференції $з$ лікарських грибів (Китай, Наньтунь, вересень 2019 р.)

Особливо хотілося б наголосити на ролі Соломона Павловича Вассера у підготовці молодих мікологів, ліхенологів та альгологів. Ще працюючи в Україні, він керував науковими дослідженнями цілої низки аспірантів і здобувачів ступеня кандидата біологічних наук не лише з України, а й інших республік колишнього СРСР (I.C. Беседіна, С.Л. Вищепан, О.С. Горбулін, С.Д. Зеленко, В.В. Никифоров та ін.). Після переїзду до Ізраїлю С.П. Вассер започаткував спеціальне вивчення мікобіоти цієї країни, в якому взяли участь молоді мікологи різних країн колишнього соціалістичного табору - Болгарії, Вірменії, Грузії, Росії, України тощо. Зазначимо, що до цієї роботи активно залучалася й українська молодь. Так, під керівництвом Соломона Павловича дисертації доктора філософії успішно (з відзнакою cum laude) захистили М.Я. Дідух, С.О. Войтюк, К.Г. Савченко, А.Ю. Бікетова та ін. Готуючи молодих спеціалістів, С.П. Вассер передавав не тільки свої знання і досвід, а й залучав до цієї важливої справи провідних мікологів світу. Більшість таких досліджень молодих майбутніх вчених також були завершені спеціальними монографічними працями, присвяченими грибам Ізраїлю. Зрозуміло, що при такому підході з університетської молоді виростали фахівці-мікологи дуже високого рівня.

Переїхавши до Ізраїлю, Соломон Павлович не поривав зв'язків 3 Україною та Інститутом ботаніки. Він організував тісне співробітництво відділів рідного інституту з Інститутом еволюції Університету м. Хайфа. Неодноразово запрошувалися до Ізраїлю для спільної наукової роботи фахівці Інституту ботаніки НАН України - мікологи Т.В. Андріанова, В.Т. Білай, А.С. Бухало, В.П. Гелюта, Г.А. Гродзинська, С.В. Решетніков та Е.Ф. Соломко, альгологи О.М. Виноградова, П.М. Царенко та ін.

Ukrainian Botanical Journal, 2021, 78(4) 
За фінансової підтримки Університету м. Хайфа згадані фахівці отримали чудову можливість здійснити низку експедицій по всій території Ізраїлю, відвідати основні гербарії цієї країни й опрацювати відповідні групи живих організмів. Завдяки цій високорезультативній співпраці було засновано серію монографічних праць "Biodiversity of Cyanoprocaryotes, Algae and Fungi of Israel", опубліковано сотні статей у високорейтингових міжнародних журналах. Безперечно, така співпраця, налагоджена С.П. Вассером, мала значний позитивний вплив на зростання професійного рівня українських учених та їхню успішну інтеграцію у світове наукове співтовариство.

С.П. Вассер $є$ членом редколегій кількох міжнародних журналів 3 ботаніки, мікології, екології та медицини, членом міжнародних наукових товариств і комітетів. В Україні він $€$ членом редколегії "Українського ботанічного журналу", багато років залишається головним редактором заснованого ним міжнародного журналу "Альгологія", який від 1994 р. перевидається англійською мовою в США, а з 1999 р. виходить як міжнародний журнал "International Journal on Algae".

Без сумніву, С.П. Вассер належить до плеяди провідних мікологів світу. Свідченням високої оцінки його наукової та організаційної діяльності $є$ низка таксонів грибів і лишайників, названих на честь Соломона Павловича: Agaricus wasseri Bon \& Courtec. (1985), Lepiota wasseri Bon (1993), Lichenochora wasseri S.Y.Kondr. (1996), Caloplaca wasseri Khodos. \& S.Y.Kondr. (2007), Pachykytospora wasseri Zmitr., Malysheva \& Spirin (2007), Leveillula wasseri Voytyuk \& V.P.Heluta (2012) та Crepidotus wasseri Kapitonov, Biketova, Zmitr. \& Á.Kovács (2021).

Яскравий талант дослідника й організатора науки в особі Соломона Павловича поєднуються 3 надзвичайно високими людськими якостями. Він завжди піклувався про своїх підлеглих, був щедрим на добро і готовим прийти на допомогу у скрутних ситуаціях. Особливо це проявилося в ізраїльський період життя вченого. Один з авторів цієї статті не раз був свідком турботливого і чуйного батьківського ставлення Соломона Павловича до своїх аспірантів, що відірвалися від родин та прибули на чужину 3 різних країн Європи. Та й сам співавтор з великою вдячністю згадує підтримку й опіку старшого колеги та його славної дружини Катерини під час перебування в Ізраїлі.

Світове мікологічне співтовариство, ботаніки і мікологи Інституту ботаніки ім. М.Г. Холодного НАН України від усієї душі вітають Соломона Павловича Вассера 3 його видатним ювілеєм i щиро зичать йому міцного здоров'я, оптимізму, родинного добробуту, подальших цікавих відкриттів у світі грибів, узагальнення набутих знань у нових фундаментальних працях. Ще багато Вам щасливих років, шановний Соломоне Павловичу!

В.П. ГЕЛЮТА, Н.А. БІСЬКО, В.П. ГАЙОВА, М.О. ЗИКОВА 
Український ботанічний журнал. 2021 • 78 • 4. Національна академія наук України. Інститут ботаніки ім. М.Г. Холодного. Науковий журнал. Заснований у 1921 р. Виходить один раз на два місяці (українською, англійською та російською мовами). Головний редактор С.Л. Мосякін

Затверджено до друку вченою радою Інституту ботаніки ім. М.Г. Холодного НАН України (протокол №. 7 від 14 липня 2021 року)

Реєстраційне свідоцтво серії КВ № 12179-1063ПР від 11.01.2007 р.

Редактор О.В. Пилипенко

Технічний редактор О.С. Бондаренко

Комп'ютерна верстка Д.С. Решетников

Формат 84×108/16. Ум.-друк. арк. 9,0. Обл.-вид. арк. 11,5. Тираж 176 прим. Зам. №

Віддруковано ВД "Академперіодика" НАН України вул. Терещенківська, 4, Київ 01004

Свідоцтво суб’єкта видавничої справи ДК № 544 від 27.07.2001 
